University of San Diego

Digital USD

2001-03-01

\title{
Crossing Myriad Borders: A Dimensional Analysis of the Migration and Health Experiences of Indigenous Oaxacan Women
}

Sharon McGuire PhD, OP, MSN, RN-C

University of San Diego

Follow this and additional works at: https://digital.sandiego.edu/dissertations

Part of the Nursing Commons

\section{Digital USD Citation}

McGuire, Sharon PhD, OP, MSN, RN-C, "Crossing Myriad Borders: A Dimensional Analysis of the Migration and Health Experiences of Indigenous Oaxacan Women" (2001). Dissertations. 297.

https://digital.sandiego.edu/dissertations/297

This Dissertation: Open Access is brought to you for free and open access by the Theses and Dissertations at Digital USD. It has been accepted for inclusion in Dissertations by an authorized administrator of Digital USD. For more information, please contact digital@sandiego.edu. 
UNIVERSITY OF SAN DIEGO

Hahn School of Nursing and Health Science

DOCTOR OF PHILOSOPHY IN NURSING

CROSSING MYRIAD BORDERS: A DIMENSIONAL ANALYSIS OF THE MIGRATION AND HEALTH EXPERIENCES OF INDIGENOUS OAXACAN

WOMEN

By

Sharon McGuire, OP, MSN, RN-C

A dissertation presented to the

FACULTY OF THE HAHN SCHOOL OF NURSING AND HEALTH SCIENCE UNIVERSITY OF SAN DIEGO

In partial fulfillment of the requirements for the degree

DOCTOR OF PHLLOSOPHY IN NURSING

March 2001

Dissertation Committee

Mary Ann Hautman, $\mathrm{PhD}, \mathrm{RN}$, Chair

Diane Hatton, DNSc, RN

Kenneth Serbin, PhD 


\section{Copyright by Sharon McGuire, OP}

\section{ALL RIGHTS RESERVED}


CROSSING MYRIAD BORDERS: A DIMENSIONAL ANALYSIS OF THE

MIGRATION AND HEALTH EXPERIENCES OF INDIGENOUS OAXACAN

WOMEN

\author{
Abstract \\ Sharon McGuire, OP, MSN, RN-C
}

The growing feminization of the migration of ethnic indigenous women, such as Mixtecs, Zapotecs and Triquis from the southern Mexican state of Oaxaca, are altering the dynamics and configuration of traditional Mexican migration, making it especially significant for the health professions. Informed by a postcolonial ecofeminist paradigm, this bi-national grounded theory study explored the migration and health experiences of indigenous Oaxacan immigrant/migrant women. Data collection using participant observation and interviewing occurred in Oaxaca, Mexico, along the US-Mexico border, and the interior of California. Dimensional analysis was used as the method of data analysis to generate theoretical understandings of these phenomena.

The explanatory matrix of dimensional analysis creates a context of colonial legacies that thwart the aspirations of indigenous women to care for their families, achieve further education or avoid stagnation, thereby spawning the conditions for migration. As the central perspective focusing the analysis, crossing myriad borders describes the difficulties and barriers that indigenous women must surmount as migrants/immigrants in an alien place. Salient dimensions within these borders of geography, culture, language, legality and new health experiences emerged as culture 
shock in coping with fractured families, language differences and undocumentedness. Participants described having to learn many new things and braving hazardous living and working conditions inimical to health. They encountered new health risks, gained some new health assets, and evolved a sequence of health seeking characterized by attributes of relationality, efficacy, and affordability. Their resolve to keep going (salir adelante) in spite of many difficulties is motivated by their investment in their children's future.

Nursing practice responding to the health care needs of this population needs to be informed by knowledge of indigenous health practices, of the health risks arising from postcolonial conditions in Oaxaca, of the safety profiles of medications and herbs from Mexico, the stresses and dangers of migration, and of patterns of health seeking and knowing. Nursing praxis should be directed at the structural conditions that induce migration, the human rights situation along the border, and at collaborating with immigrant rights groups on issues of amnesty and changing the devastating consequences of the latest 1996 immigration law. 


\section{TABLE OF CONTENTS}

\begin{tabular}{|c|c|c|c|c|c|c|}
\hline Dedication & - & - & . & - & - & - \\
\hline Acknowledgements & - & . & . & . & $\cdot$ & • \\
\hline List of Tables & - & - & . & $\cdot$ & $\cdot$ & $\cdot$ \\
\hline List of Appendices & - & . & . & $\cdot$ & & \\
\hline
\end{tabular}

Chapter I PHENOMENON OF INTEREST - . $\quad 1$

Nursing and Immigrant Health _ . $\quad$. $\quad 3$

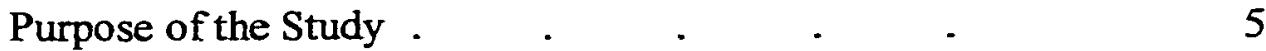

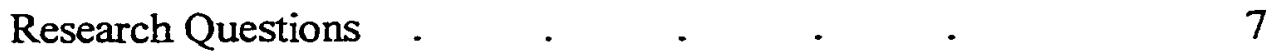

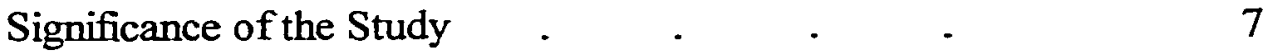

$\begin{array}{llllllllllll}\text { Summary } & . & & & & & & & & & & 9\end{array}$

$\begin{array}{llll}\text { Chapter II } & \text { REVIEW OF LITERATURE } & & 11\end{array}$

Patterns and Trends of Contemporary Migration . 13

Anthropological Perspectives on Human Population Movements 22

European Global Expansion . . . . . . $\quad 25$

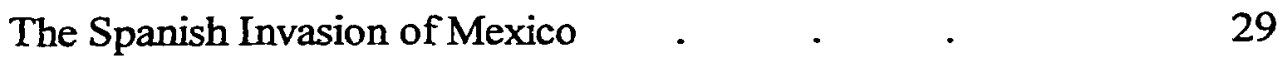

$\begin{array}{lllllll}\text { Legacies of Colonization } & \text { - } & \text { - } & \text {. } & & & 34\end{array}$

$\begin{array}{llllllll}\text { Mexican Migration North } & \text { - } & \text { - } & \text {. } & & 37\end{array}$

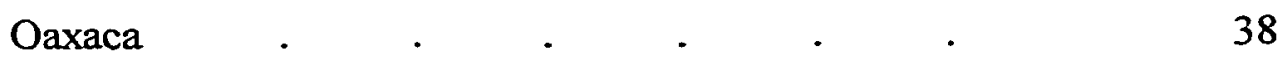

Perspectives of the Researcher $\quad$ - $\quad$. $\quad$. 44 
$\begin{array}{llllll}\text { Chapter III METHODOLOGY } & \text { - } & \text { - } & \text { - } & \text { - } & 47\end{array}$

Philosophical Underpinnings . $\quad$. $\quad$ - $\quad$. 47

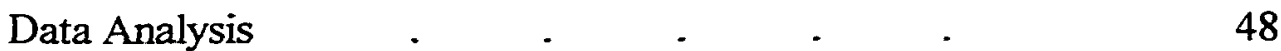

$\begin{array}{llll}\text { Computer Assisted Technology } \quad \text {. } & \text {. } & \text {. } & 50\end{array}$

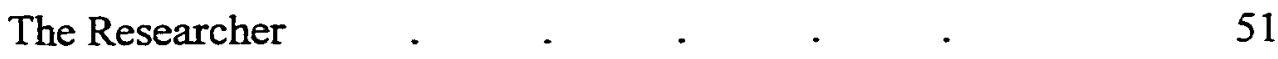

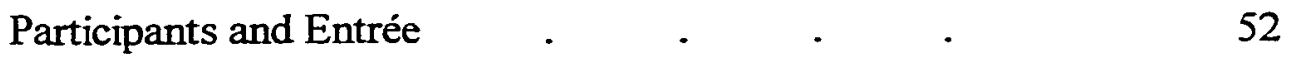

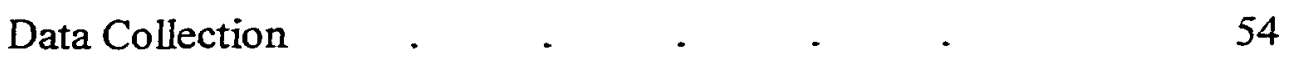

$\begin{array}{lllllll}\text { Ethical Considerations } & \text {. } & \text {. } & 57\end{array}$

Chapter IV CROSSING MYRIAD BORDERS . . 61

Dimensions and Properties (Matrix) . . . . 65

Colonial Legacies and Genesis of Migration . $\quad$. 67

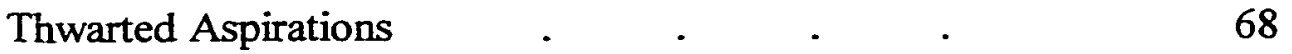

Crossing the Geo-Physical Border . . . . . 75

Crossing Political-Legal Borders 77

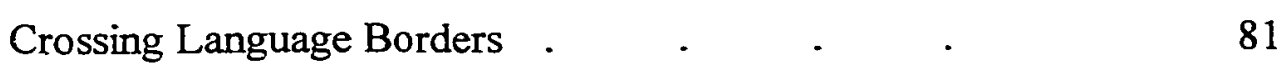

$\begin{array}{lllllll}\text { Crossing Cultural Borders } & \text { - } & \text {. } & \text { - } & \text { - } & 87\end{array}$

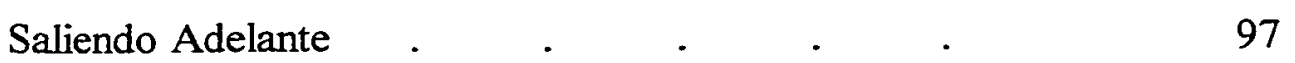

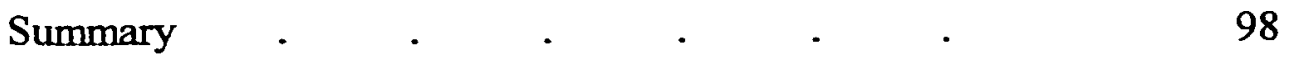

Chapter V HEALTH TRANSITIONS . . . . 99

Appraising Childhood Health Status . $\quad$. 100

Changing Health Practices $\quad . \quad$. $\quad$. $\quad$. 105

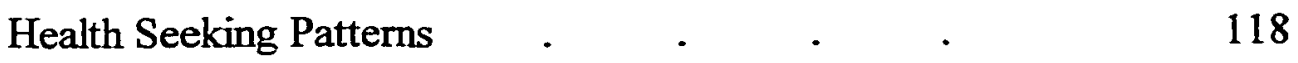

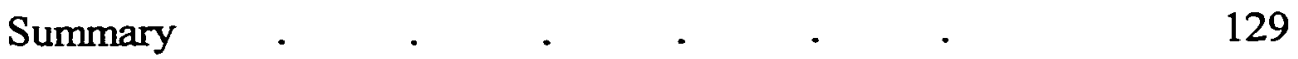


Chapter IV DISCUSSION $\quad$ - $\quad$ - $\quad$ - $\quad$. 130

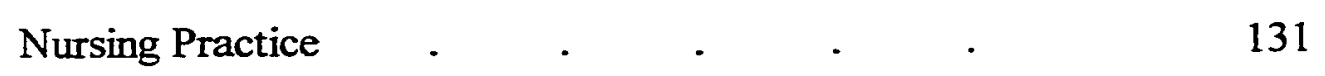

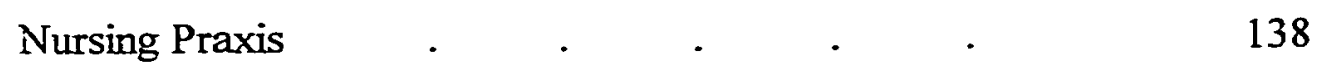

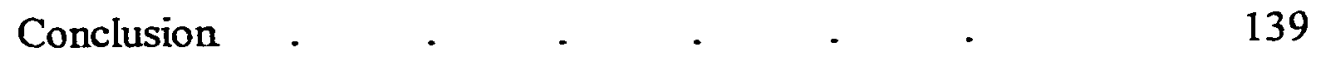

REFERENCES $\quad$. $\quad . \quad . \quad . \quad . \quad . \quad$. 


\section{DEDICATION}

This dissertation is dedicated to the Adrian Dominican Sisters of Adrian, Michigan whose love and support made this work possible. It is also dedicated to those indigenous Oaxacan women whose lives instruct us all in the meaning of love, courage and resilience. 


\section{ACKNOWLEDGEMENTS}

Many people conspired, either wittingly or unwittingly, to make this dissertation possible. I would like to acknowledge them all, but will identify those most intimately involved because of the limitations of space. First, I must thank my parents, Jean and Bob (RIP) McGuire, who allowed me, a girl child, full freedom in my childhood to explore my world and pursue my fascination with plants, animals and the world of nature. Never did they ever attempt to squelch my curiosity and spirit of adventure, thus laying the foundation for my adult life in its surprising unfolding.

I also acknowledge with deep gratitude and love, the Adrian Dominican Sisters for the opportunity to prepare for mission, ministry, and the common visions we share in a rapidly changing and suffering world. The contributions of their moral, physical and spiritual support is inestimable, in addition to their faith in my abilities and gifts. I especially thank Virginia Kleckner, OP, with whom during her term as Chapter Prioress I first explored the possibility of doctoral studies. Molly Nicholson, OP, the director of studies on the General Council with whom I consulted, has remained a constant source of support, affirmation and friendship from the beginning of our conversations. The initial and ongoing encouragement of these two women continues to evoke within me profound gratitude and deep affection.

I cannot say enough for the members of my dissertation committee. Dr. Mary Ann Hautman, the Chair of my committee, deftly guided me through the process. From our initial advisor-advisee meeting in May of 1997 I knew she would be a good match for me. She almost magically intuited my needs, gently nudged me along the road, asked incisive questions, and made the timely suggestions to keep me on track. Dr. Hautman 
also graciously offered her personal assistance and time in the technical matters of scanning the photo project and putting the images on CD-ROM. Dr. Diane Hatton, an expert in dimensional analysis, was always extraordinarily responsive and gave me so many invaluable suggestions. Our correspondence was largely electronic, but spanned the period from initial data collection in Oaxaca and Baja, California through completion of the dissertation. I also thank her for her encouragement in grant writing, especially for the American Nurses Foundation grant. I am deeply indebted to both Dr. Hautman and Dr. Hatton not only for serving on my committee, but for the exemplary models they are as faculty and committee members. I acknowledge the contribution from Dr. Kenneth Serbin from the History Department for agreeing to serve as a committee member during his sabbatical. His knowledge is wide ranging, networks of colleagues impressive, and suggestions on target.

Other doctoral faculty at the University of San Diego Hahn School of Nursing and Health Science also deserve applause for their devoted, untiring efforts to nurture and develop the scholarly potential of doctoral students. Dr. Patricia Roth, especially, has sensitively responded to students' academic needs and has been a pillar of support throughout the program for me. Dr. Dorothy Kleffel urged me to think big from the beginning to the end of the program, and provided unflagging electronic and personal support and motivation during the development of papers and manuscripts.

I acknowledge with gratitude the Transborder Institute at the University of San Diego, the Irene Sabelberg Palmer Research Award from the Hahn School of Nursing and Health Science, and the American Nurses Foundation for research grants to help fund this study. Without these awards it would not have been economically feasible to conduct 
the research. I last, but not least, give my eternal thanks to the indigenous women who are so integral to the study, for sharing their hearts, homes, and substance with me. I deeply hope that this study will make a positive difference in their lives by contributing to better health care through an enhanced understanding of their heroism. 


\section{LIST OF TABLES}

Table $1 \quad$ Ethnobotanicals Used by Oaxacans (Remedios Caseros) $\quad$ - $\quad 122$

Table $2 \quad$ Non-botanical Treatments Used by Indigenous Oaxacans $\quad$ - $\quad 124$

Table 3 Sequence of Health Care Seeking Among Indigenous Women Participants in the U.S. 


\section{LIST OF APPENDICES}

APPENDIX A

Photography Project .

APPENDIX B

Interview Guide: English Version

Interview Guide: Spanish Version

APPENDIX C

Demographic Data

APPENDIX D

Translator's Pledge of Confidentiality

APPENDIX E

Transcriber's Pledge of Confidentiality

Consent Form: English Version

Consent Form: Spanish Version

Committee on the Protection of Human Subjects

University of San Diego 


\section{CHAPTER I}

\section{Phenomenon of Interest}

The arrival of the $21^{\text {st }}$ Century finds the entire planet in flux. Individuals, families, communities and villages, and entire populations are navigating geographical spaces in unprecedented numbers. They form a living mosaic, a human river winding in variegated and ceaseless patterns of motion within and across national land borders, across seas and oceans to new places. They relinquish old places called home yet maintain ties to their homeland. Some never return. Some are suddenly forced to flee danger, environmental degradation or disasters; some flee poverty and hunger or war; some move to find work and support families and loved ones; some want to reunite with families; some search for more satisfying opportunities to advance; a few are looking for adventure. Grieshop (1997) maintains that one billion people migrate annually throughout the world, while Kane (1995) asserts that $100,000,000$ people are on the move at any one time. Although often portrayed simplistically in the media, in sum and substance single causes of migration are rare.

People move for a numerous reasons, many with hope in their hearts for some as yet to be realized dream they are unable to fulfill at home. In the United States (U.S.), a country built by immigrants, they have often been applauded as people with great courage, mettle and ambition. Conversely, they have also been vilified as hordes of invaders, thieves and criminals, sinister terrorists, and disease bearers. They have been 
admired for their artistic contributions in cuisine, art, literature, dance and music; as hard workers and contributors to the social, political and economic fabric of life in their new countries. They have also been perceived as competitors for jobs, as "foreigners" and others to be feared, as cheap labor to be exploited, and as threats to white hegemony, privilege and power.

During cycles of nativism (Crawford, 1997) the public discourse can turn virulently distortive against immigrants, perpetuating negative stereotypes and spawning discrimination and violent racist acts against them. Hostile public discourse in countries that host immigrants seems to disregard questions about the origins of these migrating people. Anti-immigrant invective fails to consider the intertwining socio-economic, political and ecological conditions of life that influence their often anguished decisions to leave home.

The media tends to present the issues of immigration simplistically so that it is not understood coherently, cohesively, or as symptomatic of processes of economic globalization (Martinez, 1997). Neither is migration, perhaps because of its magnitude and its distance from the collective memory of most of the nation and nursing, generally presented with human faces telling human stories filled with meaning and the human drama of ordinary lives undergoing extraordinary experiences.

Whatever compels them, migrants frequently face heightened risks to their health. Transnational migrants especially may suffer from anxiety and depression associated with a deep sense of loss. Women who cross borders without a trusted male escort are highly vulnerable to sexual assault, battery and rape during migration. They may suffer serious sequelae such as unintended pregnancy, or sexually transmitted disease including 
HIV infection (Shorris, 1992; Toole, 1997). Migrants often risk health and life from drowning at sea or crossing a river, freezing in a sudden mountain snowstorm, or perishing of dehydration and heat stroke crossing a desert or trapped in a transport vehicle (Eschbach, Hagan, Rodriguez, \& Bailey, 1999). They may be impaled by cacti needles, be stung by wasps or scorpions, sea urchins or jellyfish, or bitten by snakes or spiders, and suffer infections or cellulitis. They may fall prey to thieves and thugs. They endure hunger, sleep deprivation, and unpredictable weather while traveling, especially if they are on foot.

If immigrants, migrants and refugees arrive safely at their destination they may face unsafe and uncertain living and working conditions, refugee camps or dangerous neighborhoods. Frequently they face misunderstanding, hostility and discrimination in the host country. To complicate matters, migrants frequently lack access to necessary health care, may fear seeking health care because they dread detection by immigration officials, or are unfamiliar with styles and the unfamiliar language and cultures of health care delivery in the US. They may delay seeking help until they experience intolerable and serious illness conditions, or may neglect to obtain basic and available preventive care to their ultimate detriment. They may endure bothersome or debilitating symptoms as "normal" or irremediable bodily occurrences without realizing relief is available. Migration and immigration are rife with health issues that have historically challenged nursing and will continue for decades ahead to call for creative nursing responses.

\section{Nursing and Immigrant Health}

Nursing in the U.S. has a long history of dedication to the health and well being of immigrants. Immigrants bring with them a bewildering array of culturally derived health 
beliefs, practices and behaviors that are often at odds with predominant modes of biomedical thought and theory. Since the days of Lillian Wald and the Henry Street Settlement in New York City, through the decade of the 1990s, nurses have searched for ways to understand these cultural characteristics of their immigrant clients in order to promote their health and well being (Daniels, 1989; Davis, 1984; Davis \& Haasis, 1920; Dougherty \& Tripp-Reimer, 1985; Leininger, 1995; Silverstein, 1985; Wald, 1991).

The literature addressing culturally appropriate nursing care and issues surrounding notions of culture itself, based principally in Western anthropological concepts, has proliferated. Knowledge development in the area of migrant and immigrant health has been published from post migration studies with Cambodian refugees, Filipina women, the Hmong, Middle Eastern women, Afghani women, Haitians, Latinos and other cultural and ethnic groups.

Nurse theorizing on immigrant health has largely been limited to the post migration phase. Nursing must begin to build a more comprehensive theory that ineludes the origins and genesis of migration from poor countries to affluent ones. Colonial histories have exerted an ongoing influence in the lives of three-quarters of the worlds' population (Green \& Troup, 1999). The transnational migration of disenfranchised populations to affluent host countries is often characterized by historical colonial links between host countries and source countries.

Only as recently as 1995 has organized nursing officially recognized the importance of global migration to the health of the world's migrating people. The American Academy of Nursing (AAN) has called for nursing to develop a heightened awareness of global trends such as "The North American Free Trade Agreement, 
emerging microbes, internet connections, ethnic and racial diversity, and Healthy People 2000" (AAN, p. 3, 1995). Because of contemporary global trends, global postcolonial perspectives are needed on the phenomena of migration and health.

In an age of globalization innovative nursing practices directed at societal and global dimensions of migration and health are also appropriate. Although people have always traveled in quest of ways to live and be, the scope and the complexity of migration patterns today suggest it is linked to growing global inequities associated with economic globalization. The G7, a small group of rich countries that include the United States (U.S.), Japan and several European countries, dominate this process (Mander \& Goldsmith, 1996).

These observations have compelled me to begin a process of untangling the roots of migration, to explore its connections and contexts for related health issues, and to make its many patterns more intelligible to my nursing colleagues as they become clearer to me. This study was conceived to form a more holistic view of a group of indigenous women immigrants that better exposes precursors to migration, their pre-migration and migration experiences, the meanings these experiences have for them and their health, and ways to address the larger contexts of migration and associated health experiences.

\section{Purpose of the Study}

The purpose of this qualitative investigation was to explore the experiences of migration and health of indigenous women who have left Oaxaca, Mexico and migrated north to the Baja border region or to the U.S. (el Norte). Secondly, this study aimed to illuminate the historical and social context of their experiences, including health related phenomena before and during the process of migration from southern Mexico. An 
understanding of Mexico's colonial history has been critical to the study. Spanish colonization of Mexico, beginning in 1521, resulted in the economic, cultural, and political disenfranchisement of most of its indigenous peoples. The legacy of these traumas is that $500+$ years of colonial and neo-colonial policies remain operative in contemporary Mexico. Today they are embodied in neo-liberal ideology, policies and practices advanced by world economic powers, especially the U.S., through international financial institutions (Chomsky, 1999). As history and meta-context these issues will also be explored.

The study begins to build a substantive theory of the origins and experiences of migration and health using the analytical method of dimensional analysis to build grounded theory. From the perspectives of the participants, and nested within a critical view of historical context, this study constructs an integrated understanding of these phenomena that includes colonial and postcolonial antecedents to Mexican indigenous migration and health. Lewenson (1995) maintains that all knowledge has a historical dimension. Historical understanding "unfreezes" (Allen, p. 166, 1986) our thinking to permit a vision of possibilities for social change necessary to enhance health.

Attentive listening to the voices of indigenous women who have been excluded and marginalized from dominant cultures in source and host countries due to body morphology, color, foreign language (non-Spanish and non-English languages), economic and educational status, gender and culture generates specialized knowledge for nursing. Knowledge emanating from postcolonial views should be co-extensive with the development of cultural knowledge for nursing practice and praxis with this population. Examples of praxis are involvement in national and international solidarity efforts to 
create healthier conditions of life, the promotion of human rights as a health issue, advocacy for fair immigration laws, economic and environmental justice at home and abroad, and influencing health policy favorably toward this population.

\section{$\underline{\text { Research Questions }}$}

This study investigated the context of colonial history and its legacies as precursors to migration, the meanings the participants attach to migration, and their experiences of migration and health.

Two research questions were posited:

1. What are the historical and environmental precursors to the migration of indigenous people from Oaxaca, Mexico to the United States?

2. How do indigenous Oaxacan migrant women interpret and give meaning to their experiences of migration and health?

Indigenous migrant women from Oaxaca were invited to participate in the study by sharing perspectives on their own experiences.

\section{Significance of the Study}

Migration histories and testimonies are embedded with health issues relevant to nursing. Cultural, historical, socio-political, and ecological issues weave context that forms nursing's environmental domain. An understanding of life conditions in the source country before migration may identify potential health issues and risks that otherwise might be overlooked, in addition to facilitating greater global awareness (McGuire, 1998). Understanding context has been recognized as essential for creating shared meanings between nurses and their clients (Benoliel, 1996; Hinds, Chaves, \& Cypess, 1992) and as a locus of nursing activity (McGuire, 1998). Immigrants' stories create 
individual and collective histories, and contribute to the initial development of a substantive theory of their particular shared experiences.

In the century since Lillian Wald's pioneering work at the Henry Street Settlement in New York City, an impressive body of scholarly nursing literature has explored and documented the cultural phenomena of patients and immigrant communities, especially since the post World War II (WW II) era. These scholarly endeavors have helped nursing realize the importance of culture to understanding their patients'/communities' health experiences. This scholarship has generally remained confined to the post migration transition and health experiences of immigrants without examining pre-migration conditions of life. Nursing needs more theoretical understandings of migration itself as a phenomenon in today's world. The anthropological literature focuses on Oaxacan men and does not include health as central to its discussion. This study develops new knowledge of indigenous Oaxacan women's experiences of migration and health from an emic perspective for nursing practice and praxis.

Friere (1968) defined praxis as thoughtful reflection and action with the purpose of transforming the world. Chinn (1999) views praxis as thoughtful reflection and action occurring in synchrony and emanating from the whole of knowing and knowledge in nursing practice. Both of these related views of praxis capture a sense of commitment that transcends the specific moments of interaction between nurses and immigrant clients and communities to those global trends influencing their lives and health.

As a small qualitative study the findings are not generalizable, an oxymoron within the genres of interpretive research, but they do have some applicability arising 
from the understandings generated. The substantive theory generated in grounded theory is context bound (Morse, 1994). Feedback from participants during analysis verified and authenticated the evolving understanding of meanings attached to migration and health. The study creates an understanding of a piece of the world from the perspectives of indigenous immigrant women who have been historically disenfranchised and marginalized. A heavy emphasis on indigenous voices was a priority in reporting research findings, in original form and translated form. Raising indigenous women's voices to levels of audibility/visibility is ontologically faithful to a paradigm of postcolonial ecofeminism.

\section{$\underline{\text { Summary }}$}

Global migration is increasing. Patterns of migration are becoming more complex, and nurses are increasingly likely to encounter new Diasporas of immigrants and migrants in their practice settings. Cultural knowledge is critical to nursing competence with new populations but it is only one dimension that affects the health of migrating people. All people live in a historic moment and are influenced by interrelated global political, economic, social and ecological realities that are expressed locally. Migrants may articulate their reasons for moving from individual perspectives, but together they share a migration and health story with common and varying themes that constitute their own histories.

This study introduces the profession to some of the Western Hemisphere's longest dwelling peoples from southern Mexico. It begins to create better theoretical understandings of migration and health from critical postcolonial ecofeminist perspectives that are appropriate for this population. The substantive theory generated 
from this effort may serve as a prototype and launching pad for future nurse scholars whose joy it is or will become to share the lives of the nation's newest Mexican immigrants. 


\section{Chapter II}

\section{Review of Literature}

Human migration has been called "one of the greatest challenges of the coming Century" (Parfit, p. 11, 1998). Immigration to the United States has been identified as one of the major demographic, economic and political issues facing the $21^{\text {st }}$ Century (Martin \& Midgley, 1994; Martin \& Widgren, 1996). Although nursing has recently recognized the global dimensions and importance of migration for health, health care access, and cultural appropriateness it has paid little attention to the genesis of migration patterns which are historically situated and determined (AAN, 1995; McGuire, 1998). This understanding could enhance nurses' advocacy role, expand venues for practice and praxis, and lead to better health care with immigrant populations that tend to be marginalized and excluded (Hall, Stevens, \& Meleis, 1994).

\section{Nursing Research and Immigrant Health}

Nursing literature related to migration has focused on immigrant health in the host country. It has been directed at fostering knowledge and appreciation for cultural diversity for the purpose of improving cultural competence in nursing. The literature generally agrees that migration is a complex process. Lipson and Omidian (1997), for example, explored Afghan refugee issues in a U.S. social environment, and found the scarcity, character, and cultural differences in types of information and its transmission a major stressor during resettlement. Problems surrounding information, including 
language differences, affected social life, work, economic status, and intergenerational family relationships due to vast cultural differences.

Hatter-Pollara and Meleis (1995) examined role strains among Jordanian immigrant women, finding that disruption of social networks, loss of social support, and communication barriers produced a sense of isolation, nostalgia, threats to ethnic identity, and pressure for conformity. Some strategies to deal with these stressors were the quest for ethnic continuity and the recreation of familiarity. Meleis (1991) advocates knowledge development that derives from listening to and understanding immigrant women's perspectives and opinions. She has long been an advocate for understanding immigrant women's health by analyzing their identities and multiple roles as they are buffeted between two different worlds exerting opposing forces on them.

The immigrant women with whom these researchers have worked are from the Middle East and reveal histories that are distinct from that of the Americas' indigenous immigrants. An important difference is legal status upon entry into the U.S. Refugees are admitted under immigration rules and protocols recognized by the U.S. Government and the United Nations, but many economically impoverished Mexicans must enter without immigration documents. This disparity surfaced as a critical difference in the research process.

Migration theories have been an abundant product of sociology, anthropology and history. However, sociology, anthropology and history have rarely focused on the interplay between migration and health. Therefore the literature review in this chapter incorporates health concerns and the complex environments related to migration to highlight the relevance of these two interrelated phenomena, and examine multifaceted 
aspects of migration. This Chapter reviews the confluent forces of history, politics, economics, ecology and culture that form the context of migration and health. An overview of some global trends of human migrations occurring today clarifies some of the evolving patterns appearing over the world.

\section{Patterns and Trends of Contemporary Migration}

The majority of migrating people move within the geographical boundaries of their own countries from rural to urban areas, rapidly swelling urban populations in Majority Countries known collectively as the Third World, "developing" countries, or "emerging" nations. Majority Countries are home to three-quarters of the world's population (Bancroft, 1998; Gould \& Findley, 1994). These cities are generally not able to maintain adequate public health infrastructures or sufficient employment opportunities for newly arriving people (Brubaker, 1991; Garrett, 1994; Kane, 1995). To sustain life many migrants join the underground economy, peddling wares in the streets. Young women are sometimes drawn, lured, or forcibly trafficked into prostitution (commercial sex work or indentured sexual servitude), risking life and health to stay alive (Altink, 1995).

Mexico City is a prototypical example of this migratory pattern. It sits in a geological basin and is considered the world's largest metropolis with more than $20,000,000$ people. In recent years the extremes of rural poverty have driven many Mexicans, including more than 2,000,000 indigenous people of diverse ethnicities, into the metropolis. Principal among these indigenous groups are Nahuas, Otomies, Triquis, Mixtecos, Zapatecos, Mazahuas, Mazatecos, Totonacas, Mayas, Mixes, Purepechas, 
Tlapanecos, Chinantecos and Amuzgos, representing one-fifth of Mexico's indigenous population (Monge, 1998).

Densely populated shantytowns sprouting up on the periphery, and new urban slums within the city lack basic sanitation and clean water, facilitating the spread of waterborne, airborne and vector transmitted communicable diseases with microbial etiologies. Swirling dust storms exacerbate the already notorious air pollution over Mexico City, and contribute to high morbidity and mortality from acute and chronic respiratory diseases, especially asthma, (Garrett, 1994; Simon, 1997). Additional health problems suffered in these urbanized immigrant communities are related to the stress of urban poverty and depression and manifest as alcoholism and drug addiction, violence, cardiovascular diseases and cancer (Monge, 1998).

Rural poverty in Mexico also forces people to migrate north in the search for employment in the northern tier of Mexico at the periphery. Gould and Findley (1994) identify the northern border of Mexico and the U.S. as one of the three major "cliff' ( $p$. 120) regions of the world that draw migrants from the interior of a Majority country to a rich country. The borders between Africa and Europe at the Mediterranean Sea, and in Asia the border between China and Hong Kong are the other two cliff regions. In-migration to the Periphery

The maquila industry, conceived in the mid 1960s by both U.S. and Mexican Governments, is comprised of zones of manufacturing and assembly plants that have relocated to the Mexican border from affluent industrialized nations. Lower labor and operating costs, lax pollution laws and minimal health and safety standards in the workplace attract these companies, including many from the electronics industry and auto 
related industries (Dwyer, 1994; Weiss, 1992). Transnational capitalist diffusion in Mexico has resulted in nearly 4,000 maquilas along the 2,000 mile U.S.-Mexico border at ten pairs of twin cities from Tijuana to Matamoros, Mexico and San Diego to Brownsville on the U.S. side (Anzaldua, 1987; Dwyer, 1994; Weiss, 1992). The North American Free Trade Agreement (NAFTA), the 1994 multilateral trade pact between the three asymmetrical powers of Canada, the U.S. and Mexico, has accelerated the expansion of maquilas along the border as well as into the interior of Mexico and other Central American countries.

The largest maquila zone is in Juarez, directly across the border from El Paso, Texas (Castiglia, 1994; Smith \& Malkin, 1997). Tijuana, with over 500 assembly plants, is a well-recognized maquila zone to San Diego. The maquila industry hires primarily adolescent girls and young women workers, viewing this population as docile and facile to control, and ideally suited for the repetitive nature of assembly work. Wages are typically low, and health hazards abound both inside and outside the maquilas. Some maquilas illegally require pregnancy tests before hiring and even proof of regular menstrual periods among their female employees to ensure a stable workforce that will be minimally disrupted by maternity leaves or commitments to sick children that will cost the company time and money.

Workers also suffer from other health problems such as eye strain, repetitive motion injuries, chronic back strain and pain, conjunctivitis, asthma, bronchitis, GI disorders, menstrual irregularities, and serious bladder infections due to restrictive bathroom privileges and subsequent low intake of fluids among workers (Anzaldua, 
1987; Fuentes \& Ehrenreich, 1992). Attempts to organize for better treatment and working conditions are often met with reprisals such as firing and blacklisting.

In violation of Mexican law, some maquilas have engaged in environmental crime by the illegal dumping of toxic waste in the Chihuahuan desert of Juarez, which sits over the Hueco Bolson aquifier, and illegal dumping in Tijuana and the Tijuana River, causing major health problems (Simon, 1997: Weiss, 1992 \#91). Skin disorders are common in the poor colonias (neighborhoods) ringing Mexican border cities, as are Hepatitis A, tuberculosis, dysentery, bacterial and parasitic diseases.

Reproductive outcomes are a sensitive indicator of chemical exposure. The Centers for Disease Control (CDC) has reported abnormally high rates of anencephalic newborns and other severe birth anomolies, as well as abnormally high number of low birth weight babies, at border sites hosting the maquila industry (Castiglia, 1994; Dwyer, 1994; Guendelman \& Silberg, 1993). Clearly, the interplay between the maquila industry and the massive influx of migrants it has attracted has generated a wide range of health problems both within the assembly plants and in the external environment.

\section{Displaced Persons}

Displaced persons (DPs) comprise the largest group of migrants but are frequently ignored. DPs might be entire communities who are forced to relocate and resettle under government policies and decisions, or through ecological disruptions and disasters.

"Development" projects, informed by Western models, are the major causes of internally displaced people (Kane, 1995).

These projects, namely roads, dams, mining ventures, and coal fired energy plants are often funded by the multilateral lending agencies of Bretton Woods, the World Bank 
(WB) and the International Monetary Fund (IMF). These loans allegedly have often been made to corrupt governments whose officials may have personal economic interests in the proposed projects (Chomsky, 1999). Conflicts of interest might result in policy and political decisions made without local community input. According to the WB's own reports ten million people are uprooted each year, yet 300 dams continue to enter into construction annually in Majority countries (Kane, 1995; Shiva, 1993). These megaprojects facilitate the global expansion of capitalism, threatening to displace indigenous peoples (Maiguashca, 1994).

In India, Shiva (1993) denounces this process as part of global market integration and the creation of conditions conducive for transnational capitalist penetration and extraction of her country's wealth. When these processes uproot entire communities they are forced from their ancestral lands. Communal bonds disintegrate and connections with nature are severed as members are forced to relocate. She believes that irreversible processes of ecocide and genocide, with their underpinnings of racism, are masked by the terms "displacement" and "resettlement".

Dramatic ecological mutations complicate these disruptions by introducing disease vectors in regions previously free of them. The artificial reconfiguration of waterways into dams, for example, has multiplied the snail hosts responsible for schistosomiasis; larvae for the malaria carrying anopheles mosquito have proliferated. New black fly populations transmit onchocerciasis, a filarial disease that causes river blindness (Brubaker, 1991; Epstein, Cohen, \& Larson, 1997; Kane, 1995). Parasites may infect rural people who later carry them to urban centers, creating an epidemiological 
nightmare as well as the need for health services and new public health measures to contain the spread of diseases.

Related ecological disasters fueling displacement migration include floods, droughts and famine, the results of deforestation and soil erosion, and nuclear and chemical fiascos like Chernobyl and Bhopal. Diseases from pollution and industrial hazards, as in the former Czechoslovakia, and stress and emergent microbial diseases from overcrowding both result from and cause further migrations (Brubaker, 1991; Epstein et al., 1997; Kane, 1995).

War and civil strife also cause internally displaced people and populations. Neither the United Nations nor any official governments recognize persons internally displaced by war as refugees, making them nearly invisible to the world community. Privately organized groups are charged with spotty humanitarian assistance to internal refugees as happened in the case of El Salvador in the 1980's and as is happening in the case of Chiapas, Mexico today (Lundgren \& Lang, 1989; Muecke, 1992; Womack, 1999).

\section{$\underline{\text { Refugees }}$}

Refugees count among an escalating number of migrating people. Official recognition as a refugee requires flight across an international border. From the mid 1970 's to 1995 the number of refugees increased tenfold, from 2.5 million people to 23 million people according to official estimates only. A slight decrease in refugees to 21.5 million people occurred by the end of 1998 (UNHCR, 1998), but these numbers may fluctuate with new conflagrations. 
Wars and violence uproot and displace people, creating flows of refugees who become temporarily or permanently displaced. Bosnia produced two million refugees; in Rwanda and Burundi two million refugees fled fighting of genocidal proportions (Edwards, 1997). By the end of 1998 Asia and Africa became the principal regions of the world spawning refugee flights. In Africa especially, violence and environmental degradation are often intricately interrelated in generating fierce competition for land. Observers and some historians attribute these crises to the legacy of colonial rule that pit African tribes against each other and sustain internecine conflict (Edwards, 1997; Kane, 1995). In the Western Hemisphere during the 1980's Guatemala and El Salvador sent refugees into Mexico, the U.S. and Canada during conflicts in which U.S. policy and funding aided state military and para-military activity against civilian populations (Lundgren \& Lang, 1989).

According to Mayotte (1995) women and children comprise about $80 \%$ of refugees. Safety from physical and sexual assault during flight and within refugee camps is an overriding and immediate health concern. Within refugee camps continuing safety needs exist, concurrently with the need for equitable distribution of food supplies and safe water. Refugee women need the full spectrum of reproductive health care including family planning and counseling for the safe spacing of re-population efforts; they need prenatal, intrapartum, and postpartum care, treatment for sexually transmitted diseases (STDs), basic primary care for acute conditions, and attention to the psychological issues related to trauma. 


\section{Transnational Migration}

Migration across national borders is another pattern. Most transnational migration is the unilateral movement of non-European people of color moving from impoverished countries to affluent ones. An estimated 125,000,000 people, or nearly $2 \%$ of the world's population, live outside the country of their citizenship. These migrants constitute both legal and undocumented persons, refugees, asylum seekers and migrant workers (Martin $\&$ Widgren, 1996). Women predominate slightly in this pattern of transborder migration (Buijs, 1993; Matthei, 1999; Schwartz-Seller, 1994).

Many migrant workers come from a source country that was a former colony of the host country, or whose country served as a source of labor once recruited by the host country (Castles \& Miller, 1998; Gould \& Findley, 1994; Mittleman, 1994; Portes \& Borocz, 1989; Zolberg, 1989). Colonial links between host and source countries have become a salient feature of transnational migration

Europe is now home to immigrants from North Africa and the Middle East; England hosts immigrants from the Caribbean. The U.S. is the destination of émigrés from Mexico, Central America and Latin America, and other parts of the world, making it the most ethnically diverse nation on earth (Ferguson, 1997; Kane, 1995; Mittleman, 1994). Mittelman (1994) calls these migrants "flows of human capital that are linked to a hierarchical system of production and power centering on a global division of labor" (pp. 276-277). In spite of contradictions in the evolution and implementation of immigration policy in the U.S., the U.S. Congress has historically always recognized that the hidden contributions of immigrant labor to the national economy exceeds the social costs of services to immigrants (Calavita, 1995). 


\section{Women and Migration}

Women have always participated in migrations, including transnational migration. Migration scholarship until recently has tended to render them invisible, or view women migrants and immigrants narrowly as dependents of males. This view ignores female agency and denies the social contributions of women immigrants. Commensurate with feminist scholarship women as migrants and immigrants are now being recognized for their motivations, risk taking, experiences and contributions to the societies in which they finally settled (Buijs, 1993). Today women and children tilt toward the majority of transnational migrants (Hune, 1991; Schwartz-Seller, 1994; Zlotnik, 1994).

\section{Undocumented Immigrants}

Although about half of undocumented immigrants are travelers who overstay their visas, the other half cross at the U.S.-Mexico border often at great peril to themselves. People who cross at the U.S.-Mexico border come from many nations and use the border as a portal of entry. About $60 \%$ of undocumented workers in the U.S. are not of Latin American origin, yet $90 \%$ of immigrants detained by the Immigration and Naturalization Services (INS) are Mexicans (Nagengast, 1998).

Among its many draconian measures, the 1996 anti-immigrant reform act criminalizes those who are caught on a second attempt without the appropriate documents or with falsified papers, prosecutes them as felons and imprisons them (Heyman, 1999). The vast majority of these border crossers will nevertheless risk the crossing to find work. Those who cross successfully will migrate to urban areas to find work in the service sector or in domestic labor; others will join the migrant agricultural stream in an occupation that is fraught with health risks. 
Undocumented women especially face great hazards during migration as unscrupulous smugglers often take advantage of their vulnerability. Undocumented immigrants, in general, are at risk due to their need for secrecy and vigilance, and their easy exploitability (Anzaldua, 1987; Messias, 1996). Immigrant women often suffer from triple exploitation as females, workers, and foreigners (Hune, 1991). Being a woman of color and undocumented compounds the vulnerability to exploitation.

As global migration steadily increases patterns grow more complex. Within the enumerated major patterns great variability exists and patterns of smaller scale can be identified within larger ones. The scale and scope of migration suggest its relationship to the globalization of economics, transportation, communications and other technologies (Castles \& Miller, 1998). Although population movements have always been a part of human history earlier patterns were considerably simpler.

\section{Anthropological Perspectives on Human Population Movements}

The skeletal remains of ancient humanoids, Homo Erectus, found in the Rift valley in Eastern Africa, date back to 1.5 million years ago. For hundreds of thousands of years these humanoids remained in eastern African homelands expanding outward only a few kilometers each generation. By 200,000 years ago modern humans, Homo Sapiens, had developed and populated most of the Old World in small numbers (Westin, 1996). Jean Auel's quadriad of novels, beginning with Clan of the Cave Bear and ending with Plains of Passage, is an attempt to document what life was like for these groups of disparate but nomadic peoples in the northern steppes, rivers and plains of the Euro-Asian Continents. Based on archeological research these stories permit us a glimpse of the ventures of early humans in the search for food, social belonging, health and well-being. 
The protagonist, Ayla, knew about natural medicines and was a gifted healer within her tribal communities.

About 60,000 years ago, during the last great glaciation of the earth, water levels receded and humans were able to use vessels and rafts to cross deep channels of water between exposed landmasses of the Indonesian archipelago. Aboriginal peoples settled Australia in this manner. Aboriginals also settled Polynesia about 3,000 years ago and New Zealand about 1,000 years ago. Later, Polynesians, now well versed in agriculture and animal husbandry, reached Easter Island and Hawaii in what appeared to be a wellplanned endeavor to settle in these lands a few hundred years before the arrival of European seafarers. This last migration contrasts with the earlier human movements characterized as nomadic wanderings in which people lived as hunters and gatherers constantly in search of food (Westin, 1996).

\section{Early Humans in the Western Hemisphere}

The first humans in the Western Hemisphere arrived as natural driftings on the huge land mass known as Berengia connecting Asia and the North American Continent (Stannard, 1992). Eventually these first and original people, Beringeans, filtered south and east to populate the North, Meso and South of the Western Hemisphere, from the Arctic to Tierra del Fuego. Some may have arrived by sea as they sailed along the Pacific coast (Parfit, 2000). First Peoples grew to millions of inhabitants who evolved hundreds of distinct cultures and more than 2,000 languages, and who populated some regions of the Hemisphere in great numbers (Dobyns, 1966; Golden, McConnell, Mueller, Poppen, \& Turkovich, 1991; Gruzinski, 1993). This epoch spanned the Wisconsin glaciation from 80,000 B.C. to about 10,000 B.C. (Cockcroft, 1998; Stannard, 1992; Westin, 1996). 


\section{Old World Migration}

Old World historical records indicate that European and Middle Eastern migrations began to assume the character of conquest. The Phoenicians, Greeks and Romans colonized the Mediterranean Basin, and later in the $5^{\text {th }}$ and $6^{\text {th }}$ centuries A.D., the Germanic tribes expanded their territories in northern Europe as the Slavs spread through Eastern Europe, mingling with the original peoples and synthesizing both their cultures and their gene pools. Non-accommodating Celts were pushed back to the Atlantic rim from the European mainland (Westin, 1996).

After the death of Mohammed in 632 A.D., Islam expanded its territory into Spain, and $12^{\text {th }}$ century Mongol conquests instituted political and demographic repercussions from China to Central Europe. Other literary renditions of migrations present varied views of the phenomenon. Migration was rare during the Middle Ages. Peasants were virtually tethered to the land of feudal lords in Europe, the Middle East, Asia and parts of Africa (Edwards, 1997; Kane, 1995; Westin, 1996).

Migrations from 1500 A.D. to the early $19^{\text {th }}$ century consisted principally of slaves, some 14 million taken against their will principally to South America, but also to the Caribbean, the Arabian Peninsula, and in smaller numbers to North America and Australia. Later, in the 1800's as feudal systems were disintegrating in Europe, about 60 million Europeans left for new lands looking for economic opportunities and religious and political freedom. European immigrants served as a colonizing force in the Americas, Africa, Far Eastern Asian countries, Australia and Islands in the Pacific and Caribbean (Castles \& Miller, 1998; Kane, 1995). 


\section{European Global Expansion}

By 1900 most of the non-European world had been colonized by Europeans and their descendants, a process aided by the enslavement of Africans and indigenous peoples, the destruction and dissolution of their communities, and the decimation and annihilation of millions of indigenous people through violence and European infectious diseases carried by immigrant colonizers. Slavery and the brutal treatment of Africans and indigenous peoples in the colonized lands were rationalized within a dualistic framework of the "superior" white European as the preferred antithesis of the devalued and "inferior" person of color. Although instances of human slavery existing before colonialism are documented, the American Indian philosopher, John Mohawk, identifies the beginnings of racism with this global process (Golden et al., 1991). The use of pejorative language and ideology to denigrate people of color and to condemn their nonChristian religious practices was employed to rationalize invasion, land appropriations, conquest and domination of the non-European world.

Other migrations that occurred during the era of European colonization were the 12 million Chinese and 6 million Japanese who left home for other parts of southern and eastern Asia. About 10 million people left Russia and Central Asia, and 1.5 million left India for Southeast Asia and Africa (Mittleman, 1994).

\section{European Migration to the Western Hemisphere}

Immigration into the Western Hemisphere is relatively new. Taken in the great span of tens of thousands of years, the advent of Europeans to the Western Hemisphere since 1492 represents a relatively recent phenomenon in human migration to the West. The first European arrivals precipitated an escalating movement of people first from the 
European Continent, and now from the entire world into the U.S. at the beginning of the third millennium. The unrelenting flow of new people from every corner of the globe persistently authenticates this country's recent history as a country of immigrants (Freedberg \& McLeod, 1998). It is also symptomatic of things not always right in the sending countries, and the phenomenon poses new sets of health problems experienced by various immigrant groups.

From an ancient indigenous perspective, the irony is not lost that Europeans and other populations arriving in the West from other Hemispheres ought to be considered the real immigrants. Although it is almost certain that seafaring Norsemen set foot in the West several hundred years before Columbus, the arrival of Columbus precipitated some of the most far-reaching and catastrophic events ever known to humans in such a brief period. Crosby (1986) marks European migration as a departure from previous forms of human population movements by noting that Europeans and their descendents are "all over the place" (p.2) because they "leapfrogged" (p.2) around the world.

The intricate relationships between human population movements and health status seem to never have been more stark and apparent than in the first meetings between Europeans and First Peoples in the "New World". A re-examination of the impact of Columbus from critical historical and social scholarship surfaces fresher understandings of the experiences of indigenous people, and native flora and fauna since his initial navigation across the Atlantic in 1492. To grasp both the momentousness of the Old World confrontation with what is today's Mexico, and the magnitude of the impact it had on the original inhabitants, it is beneficial to catch a glimpse of Pre-Hispanic Mesoamerica. 


\section{Meso-American Natural Heritage}

Two hundred million years ago, the earth's land was joined in one contiguous supermass known to geologists as Pangaea, characterized by a homogenous biota. The geologic events that divided the Pangaea into separate land masses allowed for a spectacular evolution of geological and biological diversity in the Western Hemisphere where the land mass follows a more vertical axis that transects many biomes. What took millions of years to accomplish in evolutionary diversification was suddenly, in an instantaneous stroke of time by comparison, partially undone when the Old World collided with the Western Hemisphere (Cockcroft, 1998; Crosby, 1972; Crosby, 1986; Crosby, 1994; Melville, 1994; Simon, 1997). Perhaps no other event in the history of the earth since the seismic events that broke up the tectonic plates of the Pangaea had such dramatic ecological alterations occurred.

Amerindians had developed in isolation and entirely differently from all the peoples of the Eurasian and African Continents, evolving as separately and divergently as had the flora and fauna of the region (Crosby, 1986). Columbus and his conquistador soldiers, primed by their participation in the Spanish Inquisition (Galeano, 1997), encountered a world of mesmerizing beauty, inhabited by indigenous peoples who were perceived as deficient in light of Spanish self reference as normative (Lange, 2000). These separate worlds, therefore, constituted the conditions conducive to an ecological and cultural upheaval when they finally collided.

Indigenous peoples of Mexico and the Americas had domesticated few animals, and tended not to keep any that would alter their customary lifestyles. American horses had disappeared from the West sometime during the Pleistocene, along with the largest, 
strongest and fiercest of such animals as mammoths, mastodons, giant sloths, sabertoothed tigers, woolly rinoceroses, giant bisons and others. These extinctions were viewed by Alfred Russel Wallace as having left "a zoologically impoverished world" (Crosby, p. 18, 1972) and did not leave many of the types of animals that would have been suitable for domestication. Indigenous people had no evolutionary reason to develop certain immunities due to minimal interaction with potentially domesticated mammals that had been the sources of new pathogens in the Old World.

The largest domesticated animal of the Indians in Mexico was the llama, and smaller animals included alpacas, dogs, the guinea pig, turkeys, and the Muscovy duck (Crosby, 1972). The Indian diet in the Central Valley of Mexico was largely vegetarian and consisted of maize, chiles, tomatoes, and maguey. Grain amaranths and mesquite provided vegetable protein sources (Whitmore \& Williams, 1998), and some animal proteins came from fish and fowl. The Indians of Mesoamerica had become expert and efficient cultivators of these edible plants that had evolved as part of the hemisphere's biota (Melville, 1994). The development of agriculture enabled the rise of urban centers among settled populations, and provided the time for discovery and innovation in the arts, sciences, and other markers of cultural development.

\section{Mesoamerican Cultural Heritage}

Pre-Hispanic Mesoamerican cities and civilizations represented models of nonWestern endogenous development before European imperial expansion. Cultural achievements of Mesoamerican societies included the evolution of a cosmovision based on the relationships of equilibrium between supernatural forces and biological, human patterns of life; artistic forms expressed in pottery, jewelry and weaving; calendrics based 
on mathematics and astronomy; cohesive forms of social organization and politics; religious or spiritual practices; long distance trade in crops and merchandises; and elaborate writing systems (Carrasco, 1990; Gruzinski, 1993; Spores, 1984).

Pre-Hispanic people constructed knowledge of human anatomy with detailed names for body parts and developed healing therapies using herbals, religious ritual, sacrifice, and sweat baths aimed at eliminating the cause of disease thought to originate in supernatural events or from a neighbor's envy or bad will (Austin, 1988; Bade, 1994). Cultural achievements and practices served as the binding force for indigenous communities, finding spiritual expression in the great ceremonial centers where sacrifice was offered and members gathered to pay homage to their deities (Carrasco, 1990; Spores, 1984). The story of the Mexica-Aztec people serves as a case study to capture a sense of the great upheavals and health disasters of the colonizing experience.

\section{The Spanish Invasion of Mexico}

I come for gold, not to till the land like a peasant---Hernan Cortez

(Cockcroft, p. 9, 1998)

They crave gold like hungry swine. (Nahuatl text in the Florentine Codex)

(Galeano, p. 9, 1997)

These telling words presage both the meaning and the magnitude of the traumatic encounter between Europeans and the First Peoples of the Americas. They prophesy the intentions of the Spanish invaders, and how indigenes perceived these intentions. Hernan Cortez and his soldiers were captivated by "the incomparable Tenochtitlan" (Crosby, p. $45,1994)$, a bustiing commercial, political and religious center built as an island city within the five connecting lakes of the Valley of Mexico. With 300,000 inhabitants, it surpassed London, Seville or any other European city in size, beauty, cleanliness and 
organization, according to the chronicles of Bernal Diaz del Castillo (1928). One pride of the empire was the crystalline drinking water piped in from Lake Chapultepec. Bathing, repugnant as a pagan practice to Spaniards, was a twice-daily ritual among the Aztecs (Cook, 1998; Dobyns, 1966; Simon, 1997).

Thousands of canoes and the three causeways connecting the city with the mainland facilitated transportation and trade in merchandise and agricultural products (Stannard, 1992). Chinampas (Wright, p. 158, 1990), a highly productive agrarian system of raised beds as floating islands used recycled human and organics wastes whose disposal in the waters was forbidden. Houses were large and well constructed. Abundant rooftop gardens and streets were ablaze with colorful flowers (Cockcroft, 1998; Simon, 1997; Stannard, 1992), reflective of indigenous aesthetic sensibilities. The layout of the city, its causeways, re-use practices, and agronomy all revealed indigenous ways of knowing about public health, ecology, engineering and cultivation. Bernal Diaz del Castillo (1928), recorded this dazzling sight that conveys to readers many generations later the genius of original peoples in the Western Hemisphere:

One could see over everything very well, ... and we saw the three causeways which led into Tenochtitlan, that is the causeway of Iztapalapa by which we had entered four days before, and that of Tacuba, and that of Tepeaquilla, and we saw the fresh water that comes from Chapultepec which supplies the city, and we saw the bridges on the three causeways which were built at certain distances apart through which the water of the lake flowed in and out from one side to the other, and we beheld on that great lake a great multitude of canoes, some coming with supplies of food and others returning with cargoes of merchandise; and we saw that from every house of that great city and of all the other cities that were built in the water it was impossible to pass from house to house, except by drawbridges which were made of wood or in canoes; and we saw in those cities temples and oratories like towers and fortresses and all gleaming white, and it was a wonderful thing to behold. (p. 269-270) 
Lust for gold incited Spanish atrocities against the Mexica people who drove them from the city in the Noche Triste (Night of Sorrows) (Leon-Portilla, 1990; Stannard, 1992). However, the Mexica underestimated the avarice of the newcomers. A second assault followed, aided both by the forced conscription or recruitment of indigenous allies resentful of Aztec tribute (taxes and human sacrifice) requirements, and the biological allies that devastated American indigenes: Epidemics and other bio-invasions. After an eight-month siege, and after half the population had died from smallpox, the conquistador army razed the beautiful city, massacring 120,000 citizens, including women and children. One indigenous priest-poet recorded:

Broken spears like in the roads; we have torn our hair in our grief. The houses are roofless now, and their walls are red with blood... Elegy for Tenochtitlan (Cited by Leon-Portilla, 1990)

The destruction of the city symbolized the colonial attack on memory and culture, indigenous knowledge, and the destruction of its economic base essential for cultural survival, auguring in the next five centuries of racism and negating the levels of development of indigenous societies (Golden et al., 1991; Lange, 2000). The epidemics forthcoming severely compromised the ability of indigenous peoples to resist and prevent the colonization of their ancient home.

\section{The Epidemics}

Smallpox started the great round of infectious diseases that afflicted Mexico for the next three centuries, initiating the "microbial unification" (Berlinguer, p. 582, 1999) of the world. Other previously unknown illnesses such as bubonic plague, pneumonic plague, typhus and cholera, typhoid fever, pertussis, scarlet fever, malaria, diphtheria and influenza followed. The slave trade introduced yellow fever with its mosquito vector, 
Aedes Aegypti, in the $17^{\text {th }}$ Century. Within a century the indigenous population was reduced from 25,000,000 to 1.5 million people (Cook, 1998; Galeano, 1997; Stannard, 1992). Indigenes witnessed their own demise and disappearance: "once there were masses of people", and "on the contrary, the region was full of people" (Gruzinski, p. 81, 1993) wrote one indigenous witness.

By 1810 , shortly before independence from Spain, fifty epidemics had swept through Mexico (Berlinguer, 1992; Cook, 1998; Crosby, 1972). Scholars dispute the health status of pre-Columbian people (Iris Engstrand, $\mathrm{PhD}$, Personal Communication, March 29, 2000) but testimonials from indigenous witnesses claim they generally lived healthy and long lives if they survived childhood illness (Gruzinski, 1993; Treviño, 2000).

Pre-Hispanic illnesses had included fevers, including $1 / 3$ and 1/4th degree gradations; diarrheas, bloody diarrheas, scabies, pustules and swollen glands, and eye diseases. GI disorders often led to dehydration. Few epidemics occurred, and rarely killed adults. They were considered punishment by the gods. Skin lesions erupted but researchers have been unable to identify microbial etiologies. Maternal mortality was leading cause of death in women of childbearing age, and half of infants died before their first year of life. The death of infants below one year of age and of elders was considered normal, but the death of adolescents and adults was considered abnormal (Treviño, 2000).

After the arrival of the Spaniards indigenes attributed the phenomenon of epidemics to "the fact of having changed customs" (Gruzinski, p. 81, 1993) and the collapse of pre-colonial standards of living, recalling that "plagues were rare" (p. 81). 
Lacking immunity, they seemed not to understand the new illness phenomena that were decimating their numbers (Golden, 1991). These epidemics and pandemics were commensurate with other ecological catastrophes introduced by the non-native flora and fauna brought by Europeans.

\section{Colonizing Nature}

Shiva (1997) claims that European colonization of the world included the colonization of nature. The second voyage of Columbus to the Antilles in 1493 heralded the beginnings of European agriculture in the Western Hemisphere. Cattle, pigs, sheep and goats, seeds and cuttings for wheat, chickpeas, melons, onions, radishes, salad greens, grape vines, and fruit stones for founding orchards comprised new flora imported by the Spaniards. Bananas and sugar cane took hold on profitable plantations, land taken from indigenes. Unintentional arrivals included the European rat, carrier of the flea vector of plague, other vermin and the seeds of many weeds ensconced in furs, textiles, animal dung and numerous other hiding places (Crosby, 1994).

Grazers such as cattle, horse and sheep populations exploded beyond control in the rich grasslands causing massive soil erosions in the Mexican countryside. Livestock strayed onto Indian communal fields, eating and trampling plants, causing many to vacate their lands that then were appropriated by the new colonizers for ranching. Communal lands became private property, a concept that appeared in Europe at the beginning of the Modern Age and influenced the colonial mentality. Displaced by livestock, colonizers, and force, a landless class of Indian laborers was born into peonage for Spanish initiatives such as building new towns, mining and textile factories (Galeano, 1997; Simpson, 1941; Spores, 1998; Stannard, 1992). 
Many other indigenes died in the mines of exhaustion and hunger (Berlinguer, 1992). The ideological justification for such treatment lay in the social construction of the Indian as pagan, savage (Cockcroft, 1998; Stannard, 1992), ignorant and lazy, a method delineated well by Memmi (1965), and essentializing the ethnically diverse indigenous peoples under a rubric of the generic "Indian" (Varese, p. 15, 1991).

The substitution of the Indian digging stick by the Spanish plow replaced ecologically designed indigenous farming methods of terracing and chinampas with Spanish pastoralism and plowing, and led to further soil erosion by destroying ground cover. Deforestation to build colonial towns and mines hastened environmental degradation, subsequent flooding and the displacement of native peoples (Crosby, 1986; Melville, 1994; Simon, 1997). In spite of these duresses, indigenous groups mounted efforts to resist colonial tyranny, and later, ruling Mexican elites. Struggles to regain land, sometime led by indigenous women, were brutally suppressed (Cockcroft, 1998). However, the cumulative trauma of losses suffered by indigenous Mexicans left legacies that persist to this day.

\section{Legacies of Colonization}

Life is wilted, and dead is the heart of its flowers; those who dip their gourd to the bottom, those who stretch everything until it breaks,' damage and desiccate the flowers of others... Pugnacious by day, conflictive by night, assailants of the world... of those who have come from beyond... They Christianized us but they exchange us between them as though we were animals. [100]

(Mayan priest-poet Chilam Balam Cited by Leon-Portilla, 1990) 
Floggings, forced slave labor, the massive rapes of indigenous women, and the cruel slaughters and burnings of entire communities caused epidemics of suicide among indigenes whose psychological and cultural resistance deteriorated with this trauma. Survivors were confined to impoverished regions, often with little arable land and with uncertain titles of property or possession (Berlinguer, 1992; Womack, 1999).

Mexican anthropologist Leon Portilla (1990) elaborates a litany of traumas resulting from colonization: Loss of confidence in their own abilities; a diffidence to fighting in defense of their rights; in certain cases, a shame of speaking in public in their own language, fearful of the social consequences of revealing their identity; their isolated circumstances and the barriers that constrain free expression of their needs and perspectives; their frequent lack of the most elementary public services such as health and bilingual education.

The legacies of colonization are also structural. At the core of these legacies is racism, accounting for a rigid caste system based on color, class, gender and heritage, and national and regional policies, legal structures, educational institutions, ideology and the "semiotic field" (Slemon, p. 46, 1995) that maintain the system. Like many other formerly colonized countries, political independence did not alter colonial structures of power, only the players (Ashcroft, Griffiths, \& Tiffin, 1998).

A great paradox in Mexico is its fascination and pride in its indigenous past juxtaposed against non-assimilated Indians and policies that perpetrate human rights abuses against them in Mexico. Violations of the rights of Mexican indigenes range from the denial of rights to their land, their culture, and their language to the torture, illtreatment, and extra-judicial execution of political activists; repression of independent 
political organizations; exploitation and extortion of peasants and workers (Nagengast, Stavenhagen, \& Kearney, 1990s; Ross, 1997; Valdez, 1998).

The $20^{\text {th }}$ Century

The Mexican Revolution of 1910 demanded the redistribution of Mexico's national land, nearly all owned by 800 latifundistas (huge haciendas). Many wealthy foreigners living outside the country owned these vast tracts of land. Article 27 of the new Revolutionary Constitution of 1917 mandated land reform and political change, representing hope for Mexican small farmers, the majority indigenous (Cockcroft, 1998; Galeano, 1997; Ross, 1998; Valdez, 1998).

The Green Revolution, a joint 1943 initiative between the Rockefeller Foundation and the Mexican Government to increase agricultural production for export, used new hybrid seeds that required ever more water, fertilizers and chemical pesticides. As insects and fungi adapted, and fallowing and intercropping were abandoned, small peasant farmers were squeezed out in favor of agribusiness. The policies of the Mexican Government and extraneous funding agencies such as the Ford Foundation, U.S. Aid, European Economic Community Development and the World Bank (WB) have eroded the gains made from agrarian reform, the deliberate but covert intent of these policies (Barkin, Ortiz, \& Rosen, 1997; Cockcroft, 1998; Wright, 1990).

Structural adjustment programs mandated by the WB and the International Monetary Fund (MFF) as a condition for loans in 1982 precipitated the economic crisis that triggered new migration from the southern state of Oaxaca, and exacerbated traditional migration routes (Herida \& Purcell, 1996; Rivera-Salgado, 1999). As a neoliberal policy this requirement anticipated the North American Free Trade Agreement 
(NAFTA) of 1994. Just before NAFTA President Salinas dismantled Article 27, ending land reform and thus extinguishing hope for Mexican peasants.

As a trilateral asymmetrical agreement among the United States, Canada and Mexico, NAFTA has accelerated the influx of foreign speculative capital and designs on Mexico's rich resources in privatization schemes that severely heighten the threats to indigenous communities and their ability to survive (Ross, 1997). As a symbol of economic globalization NAFTA opens the way to powerful Transnational Corporations (TCNs) to maximize profits and to control economic, social, political and cultural life at the expense of Mexico's most vulnerable people and their environments (Berlinguer, 1999; Chomsky, 1999; Navarro, 1999). Colonial legacies then link with current economic policy to help explain the newest feature of a long tradition of transnational migration to the U.S. from Mexico.

\section{Mexican Migration North}

Mexico, the world's $14^{\text {th }}$ largest country, leads the world in sending emigrants to the U.S. (Martin \& Widgren, 1996). Mexican immigration increased substantially before World War I under a "back door" (Calavita, p. 236, 1995) federal policy, and again during the Bracero Program between the U.S. and Mexico between 1943-1965. The Bracero Program was instituted to offset field labor shortages caused by World War II (Gould \& Findley, 1994; Mittleman, 1994; Portes \& Borocz, 1989; Smith, 1992). Social activism against the abuses inherent in the program later led to its demise. By then 5,0000,000 Mexican migrants had settled in the U.S. and had begun to bring their families in the social networks that formed with resettlement (Freedberg \& McLeod, 1998; Gonzales \& Rodriguez, 1999; Simon, 1997; Zabin, Kearney, Garcia, Runstein, \& Nagengast, 1993). 
Today the U.S.-Mexico border is both the busiest and the most policed in the world, especially since the latest 1996 Federal immigration legislation was enacted. The Immigration Reform and Immigrant Responsibility Act, authored by Republican Representative Lamar Smith of Texas and known as IRIRA, is a draconian measure that forces undocumented migrants into inhospitable territory as they attempt crossing. Driven by desperate economic need or political persecution, undocumented migrants risk life and health as they face dangers such as drowning, freezing, or dehydration. They risk assault and even murder by a criminal underworld if they rely on unknown coyotes, or border smugglers (Alvarez, 2000; Dunn, 1996; Eschbach, 1999; Oaxaqueño, 1999).

If they cross successfully, more dangers await, such as auto accidents or suffocation in freight compartments of trucks or trains. Increasingly undocumented migrants face vigilantes on the U.S. side (Latino News USA, National Public Radio, May 21,2000 ). Aviles (1999) has recently identified human rights violations occurring along the border as a public health issue. The escalating number of migrant deaths since the inception of increased policing is of concern to human rights activists (Aviles, 1999; Huspek, Martinez, \& Jimenez, 1998). Nevertheless, migrants keep coming, among them thousands of indigenous people from Oaxaca, located in the heart of the ancient Mesoamerica.

\section{Oaxaca}

Oaxaca, Mexico's fifth largest state is divided into seven regions. It is largely mountainous, making access difficult. Before the arrival of the Spaniards, it was known as the "heavenly and esteemed land" (Nudzavuinuhu) (Simon, p. 35, 1997). The Mixtec region was known as the "cloud land" (Wolf, p. 41, 1959) in the Nauhuatl language, and 
Mixtecs as "cloud people" (Ross, p. 307, 1998). Zapotecs were named after the zapote tree. Both ethnic groups evolved separate tonal languages from the same parent tongue Oto-Zapotecan, and each has many, often mutually unintelligible, dialects. Decimated by epidemics, native communities of Oaxaca began to recover between 1640-1660 from the severe populations losses incurred a century earlier (Spores, 1998; Wolf, 1959).

With the disappearance of Mesoamerican City-states, the colonial period spawned small isolated villages that perceived their competition for land with each other, a dynamic that served Spanish, mestizo, and co-opted indigenous nobility interests in domination. From these processes came strong village identities, most villages syncretically incorporating ancient religious beliefs based on relationships to the natural world with Catholic beliefs and patron saints for each village (Kearney, 1998; Monaghan, 1995).

Together with Chiapas to its southeast and Guerrero to its west, Oaxaca forms Mexico's Southern Poverty Corridor (Kastelein, 2000; Rivera-Salgado, 1999). It is home to 16 ethnic indigenous groups, the most numerous of them Zapotecs and Mixtecs. Its geography and its people kept it from full incorporation into the Aztec Empire, and made Spanish control difficult and largely limited to the fertile Central Valleys (Kastelein, 2000; Sesia, 1990; Spores, 1984, 1998). Both Zapotecs and Mixtecs were pushed into the mountains where they farmed less fertile hillsides and some small fertile valleys dependent on seasonal rains. The Spaniards continued to demand tribute and extract wealth and the Mexican Government has historically abandoned the Mixtec region to indigenes with little investment for infrastructure or other development (Kearney, 1998). 
Together these historical roots contribute to health problems today in Oaxaca that are born of great poverty.

\section{Health in Oaxaca}

Health and socioeconomic indices in Oaxaca are among the lowest in Mexico. Nearly $1 / 3$ of the population is preliterate compared to $15 \%$ in the rest of Mexico, and infant mortality is twice that in the rest of Mexico. A high prevalence of preventable diseases is associated with insufficient alimentation, and poor sanitation and hygiene as common conditions of life. Acute respiratory infections, enteritis and other gastrointestinal diseases and parasites, and anemia are endemic. Life expectancy is 12 years lower than the reported 60-year average in Mexico (Sesia, 1990; Winter, Morris, \& Murphy, 1993). Maternal mortality is second only to Chiapas in Mexico due to hypertension in pregnancy, post partum hemorrhages and infections (Noticias, 2000).

A Oaxacan organization known as Aseteco has found problems ranging from elevated deaths from cervical cancer in women, malnutrition in infants and young children, to esophageal obstruction from strictures, extrapulmonary tuberculosis, and respiratory problems from wood burning stoves. In Mexico as a whole, a woman dies of cervical cancer every two hours, that is 12 women daily (Molina, 2000; Reyes, 2000).

Fecal contamination of air and water in areas of extreme poverty cause infectious diseases. Efforts by Aseteco are focused on introducing stoves that conserve wood and are elevated well off the ground, and building composting toilets that use lime to eventually produce fertilizer (Reyes, 2000). A serious and growing problem in Oaxaca is AIDS from returning migrant males who infect their wives or partners. By October of 2000 , more than 900 deaths from AIDS had been registered, with unregistered deaths 
unknown (Arrazola, 2000). The circular migration of Oaxacans makes AIDS one of the most pressing new health problems in Oaxaca.

The Indigenous Mexican Diaspora in the United States

Respected Mexican essayist, Ruben Martinez (1997) asserts that an "enormous number" (p. 37) of Mexican indigenous people live north of the border. Mexico is home to $10,000,000$ indigenous people. Mixtecs and Zapotecs from Oaxaca, Totonacas from Veracruz, Nahuas from Guerrero, and Purepechas from Michoacan comprise the major portion of these indigenous migrants (Martinez, 1997; Monge, 1998; Salgado, 1998a). Some Triqui, a small tribe from the most remote mountainous regions of Oaxaca, are also numbered among them (Zabin et al., 1993).

In Mexico, the highest concentration of Mexican indigenes lives in the Mexican Poverty Corridor. A few Oaxacans joined the Bracero program in the 1940s. By the 1970's 355,000 people from the Mixteca region of Oaxaca had left for Mexico City, Oaxaca City or the northern fertile valleys of Mexico to work as farmworkers, joining the nomadic streams from the states of Michoacan, Guerrero, Oaxaca, Morelos, Hidalgo, San Luis Potosi and Chiapas (Monsivais, 1995; Wright, 1990).

Transnational migration from the northern fields of Sinaloa and Baja took hold in the 1970's and accelerated with the 1982 Mexican economic crisis and the implementation of the neo-liberal economic model. The Center for Research of Rural Integral Development in Mexico projects that three in ten Mixtecs will emigrate permanently, four will migrate temporarily, and three will remain home because of the reduction of agricultural land by $50 \%$ in the Mixteca region (Monsivais, 1995; RiveraSalgado, 1999; Shorris, 1992; Wright, 1990). Triquis from the Mixteca region, and 
Zapotecs from both the Central Valleys and the Zapotec regions in the Sierra also are leaving Oaxaca but little health literature is written about them. Zapotecs tend to concentrate in urban centers like Los Angeles and Mixtecs and Triquis gravitate principally to rural agricultural regions in the U.S. The urban census of Mixtecs is unknown (Simon, 1997; Wright, 1990; Zabin et al., 1993).

Indigenous Oaxacans have formed diasporas in 23 states in such disparate places as Alaska, California, New Jersey, New York, Oregon, Washington, Utah, Idaho, Nevada, Texas, North and South Carolina, Illinois and Florida. Oaxaca emigrates about 100,000 people annually to urban centers and to the U.S. where about $1,000,000$ Oaxacans now live. One-half million Oaxacans reside in California (Matias, 2000; Oaxaqueño, 1999; Rivera-Salgado, 1998a). The populations of indigenous immigrants continue to swell with new migrants, even children who hope to cross the border and reunite with unauthorized parents already here (Hernandez, 1999; Oaxaqueño, 1999).

Mixtecs tend to concentrate in rural areas and engage in agricultural labor. They now form about $5-10 \%$ of the farm labor force in California as a whole, $30-40 \%$ of the force in California's San Joaquin Valley. The Mixtec are generally found in the least desirable jobs earning the lowest wages, and are often subject to abuses and the dangers in one of the most hazardous of occupations (Ferriss, 1999; Rothenberg, 1998; Salgado, 1998; Wright, 1990; Zabin, 1993). Zapotec immigrants tend to congregate in urban areas, as their numbers in Los Angeles testify. According to Simon (1997) the major reason for the U.S. bound migration is expressed by indigenous male peasants as "porque la tierra ya no da" (p.35)...that is, the earth no longer gives. This theme exposes the contributory 
role of the physical environment to migration from Oaxaca, but how indigenous women view the situation is unidentified.

\section{Potential Health Risks:}

Potential health risks in the host country are associated not only with genetics, gender or age but also to the nature of the work and living situations of indigenous immigrants because of their poverty, ethnicity and language (Rothenberg, 1998). Poverty is recognized as the most debilitating impediment to health related to low education, lack of potable water, sanitation and hygiene, under immunization, poor nutrition and limited access to health care. Immigrants in general have greater health risks than nonimmigrants related to stressful transitions, and for women multiple roles (Hegyvary, 2000; Meleis, 1997). Oaxacan women without documents may assume the greatest risk.

The cultural, social and political backgrounds of Oaxacans distinguish them from mestizo Mexicans who have a longer history of immigration from central and northern Mexico. Medical anthropologist Bonnie Bade (1994) has compared rural Mixtecs to indigenous refugees from Southeast Asia such as Hmong and Khmer speakers. Because of their language and culture, they confront powerful transforming and traumatic experiences during and after migration travel. This population, with its own unique history of migration, has been largely marginalized and invisible to mainstream society in the U.S. (Zabin, 1993).

Bade's (1994) ethnographic study observed the difficulties that rural Mixtec farmworker women in California's Central Valley had with access to clinical services due to the nature of health delivery services and with cost issues. She described some health beliefs, experiences and practices of Mixtec women both in Oaxaca and in California 
using case studies, finding that Mixtec women engaged in both Western and indigenous health care practices. The turn to indigenous healing practices appeared to maintain a sense of ethnic and cultural identity and allowed for an expression of resistance in the face of the crushing demands of Western health delivery systems such as multiple appointments, child care, transportation problems, and cost.

Greishop (1997) found that beliefs in omens related to health status diminished among Mixtec males with increased duration in the U.S. Published literature that examines interrelationships between migration and health, health risks and perceptions, health strengths, patterns of health seeking, and variations in health beliefs among indigenous Oaxacan women is virtually non-existent.

As I undertake this effort to identify salient dimensions of the migration and health experiences of indigenous Oaxacan women I make my own perspectives, background and position as researcher clear. The window through which I see the world has shifted, expanded slightly and become further synthesized since the original proposal, but remains faithful to emancipatory goals.

\section{Perspectives of the Researcher}

I claim an affinity with feminist, ecofeminist, and postcolonial critical perspectives. Although I entered the doctoral program with some diffuse awareness of postcolonial and critical perspectives, and ecofeminism, it is through the readings and study of the foundations and tenets of these philosophical views and paradigms that I realize what a good fit they are for the way I see the world, make choices, and live my life. In the first six months of examining migration literature, it became apparent inductively that ecofeminism and critical ecofeminism offered a powerful epistemic 
paradigm through which to conduct this exploration. Postcolonial theories tied all these perspectives together into a unifying postcolonial and critical ecofeminst lens. These have been clarifying experiences that allow for forthrightness in representing myself in the research.

Women especially have distinctive stories to tell that mirror their strength and resilience, their ability to take responsibility and resist oppressive circumstances. Since the 1930s they have outnumbered males in legal migration to the US and they are key protagonists in undocumented immigration (Matthei, 1999). Postcolonial critical ecofeminist perspectives allow for a better coherent understanding of the socio-economic, political, ecological and ideological influences in the lives of postcolonial peoples within their societies and cultures, and therefore to better understand macro-environmental influences on their migrations. The feminist insight that the personal is political has its corollary in that the political is also personal.

\section{Critical History}

Certain nursing scholars assert that the environmental domain of nursing has been conceived in such a limited manner that the environmental origins of health problems and phenomena of relevance to nursing have been poorly understood or ignored (Chopoorian, 1986; Kleffel, 1991). Until recently, indigenous people and their environmental stories have tended to be ignored, downplayed or misrepresented in dominant versions of the colonial history of the Americas.

The epistemic power of ecofeminism is in its ability to critically consider historical dimensions of the oppression of women, people of color, and nature from their perspectives (McGuire, 1998). Therefore, exploring colonial and postcolonial history and 
human experience from the "underside", the side whose stories yet need telling because they have been written out of traditional and dominant ways of historicizing is consistent with feninist and ecofeminist tenets, and postcolonial theories. The critical scholarship of ecofeminism illuminates the political nature of history, both personal history and the collective history of a people descended from some of Mexico's First Peoples.

Some newer historians have also embraced views that are more critical and taken advantage of the scholarship of the social sciences, biologists, epidemiologists and ecologists to begin writing new and vibrant histories of the Americas. These new histories differ substantially from those of the bardic historians of the last century whose European ethnocentric perspectives conceptualized and promoted their biographies of famous white conquering males as worthy history (Crosby, 1994).

The personal histories and the collective history of indigenous people who have emerged five centuries after Spanish and European colonization and domination to claim their rightful place in human history are enfleshed in these times. The struggles in Chiapas, Oaxaca, and Guerrero to resist persistent encroachment on their lands, to resist displacement, or to reclaim lands taken from them, and to develop from a position of selfdetermination and cultural autonomy are writing contemporary history in southern Mexico (Cockcroft, 1998; MacEoin, 1999; Maiguashca, 1994; Womack, 1999). 


\section{Chapter III}

\section{Methodology}

The research approach selected for this study was grounded theory $(\mathrm{GT})$, first developed in the 1960's by Glaser and Strauss (1967). Grounded theory belongs within the genre of qualitative approaches to research. Because the purpose of GT is to develop theory about the phenomenon under investigation, the concepts for the theory arise from an ongoing analysis of the data as it is collected (Baker, Wuest, \& Stern, 1992; Barnes, 1996; Benoliel, 1996; Glaser \& Strauss, 1967; Hutchinson, 1993; Lowenberg, 1993; Stern, 1980; Strauss \& Corbin, 1990, 1994).

GT is largely an inductive analytical approach especially apropos when little is known about the area under study, or a fresh slant is needed on a known topic. It is used to illuminate the subject area for understanding or new perspectives (Field \& Morse, 1985; Hutchinson, 1993; Morse, 1992; Stern, 1980; Strauss \& Corbin, 1990). The theory generated must faithfully reflect the perspectives of the participants (Glaser, 1992). When grounded theory is used in a cross-cultural setting with participants from a culture different from the researcher's culture, personal or professional experience with that culture is an imperative (Barnes, 1996).

\section{Philosophical Underpinnings}

Grounded theory is rooted in the philosophy of symbolic interactionism. Blumer (1969) refined symbolic interactionism from earlier insights postulated by Mead to 
explain the social nature and origin of self. Symbolic interactionism is a theory about human behavior and an approach to inquiry about human conduct and group behavior. The social worlds of human beings are replete with symbols, principal among them language, which people interpret in ways meaningful to themselves (Annells, 1996). Blumer (1969) postulates three premises:

- The meanings that things have for persons will determine what actions will occur toward those things.

- This meaning is derived from social interactions.

- An interpretive process is used to direct and modify the meanings as the situation is dealt with by a person

Concepts inherent in symbolic interactionism are human agency and reciprocity since humans are seen as interacting purposefully with environments and making decisions relative to the symbolic meaning the environment has for them. One criticism that has been leveled against symbolic interactionism within sociology is that it ignores macro-level influences such as institutions or class struggle that can place objective restraints on social action (Annells, 1996). The symbolic interactionist is concerned with interpersonal dynamics and operates within a personalized context of awareness of the other's identity, whether a person or group. The awareness context can be open, closed, suspicious or one of pretense (Glaser \& Strauss, 1967).

\section{Data Analysis}

Dimensional analysis as it has been taught and refined by Schatzman (1991) was the method of data analysis. Although dimensional analysis is rooted in the core ideas and principles of grounded theory, it has its own "procedures, epistemological assumptions, and logic" (p. 303). As an analytical method to generate grounded theory, 
dimensional analysis is rooted in symbolic interactionism. The analysis proceeds according to the logic of an explanatory matrix in which dimensions of the phenomenon under study are identified and made explicit, each as a potential organizing perspective. Eventually one perspective is selected by the researcher as the central theoretical understanding of the action, interaction, or process in the phenomenon, and related subdimensions are clustered around the designated perspective in the matrix to explain "what all is going on here" (Robrecht, p. 172, 1995). The explanatory matrix is the cornerstone of dimensional analysis yielding structure and context for the theoretical explanation (Kools, McCarthy, Durham, \& Robrecht, 1996) of the empirical phenomenon. Dimensional analysis is based on a theory of "natural analysis" in which researchers draw on past experiences and knowledge as a cumulative and integral part of their thinking. Just as human behavior is considered symbolically interactive within this philosophical paradigm, so too the researcher interacts symbolically with the data. Therefore, natural analysis and dimensionality are considered important tenets of dimensional analysis (Kools et al., 1996; Robrecht, 1995). The method of dimensional analysis proceeds through three phases: Designation, differentiation and integration (Kools et al., 1996).

\section{Designation}

In the phase of designation the researcher identifies and labels the dimensions and properties observed in the data, offering the researcher a lexicon with which to continue data analysis. As the researcher conceptualizes at ever more abstract levels from the empirical situation, prioritizing a perspective is held in abeyance to allow for both specificity and comparison of concepts (Kools et al., 1996; Schatzman, 1991). The 
principle way of documenting fidelity to the evolving process is through the writing of theoretical memos (Chenitz \& Swanson, 1987; Kools et al., 1996). Data collection and analysis continue until enough dimensions are identified that sufficiently reveal all that is going on in the data. At that point, it is time to move to the use of the explanatory matrix. Differentiation

In this phase, because the full scope of the complexity of the phenomenon has been realized, data are no longer expanded but theoretical sampling is continued. The task in this phase is to recognize the salience of dimensions, organize them logically, and conceptually link them into the explanatory matrix in a meaningful way. The matrix includes dimensions addressing context, conditions, actions/processes and consequences organized around the central perspective selected to analyze and theorize the phenomenon. The perspective chosen is the dimension that has been determined to provide the most fruitful explanation of the phenomenon under study (Kools et al., 1996). Integration

This final phase of dimensional analysis is the construction of the coherent narrative explicating the theoretical understanding of the phenomenon (Kools et al., 1996). The story told becomes the substantive theory, one that is recognized by the participants as their experience, and that makes sense to the researcher and readers.

\section{Computer Assisted Technology}

As an adjunct to careful readings and immersions in the data by hand the program NVivo was employed to help organize the data as analysis proceeded. NVivo is a sibling software program to Nud*ist4 (non numerical unstructured data by indexing, searching 
and theorizing). A sophisticated resource, NVivo allows for scanning photos and images and for using color-coding of text as well as other facilitative features for analysis.

Richards (1999) points out the NVivo is more than an update and improvement on Nud*ist4, but is such a radical departure from Nud*ist4 that it represents a new paradigm in computer assisted analysis of qualitative data. A major feature of NVivo is its ability to retain "rich data" (p. 414) that is a wide, diverse and complex range of information collected over an extended period. It was suitable for this study.

\section{The Researcher}

As the principal bilingual investigator in this research endeavor, I had had a lengthy history of working directly, or in an advocacy role, with immigrant populations from diverse regions of the Caribbean, Mexico, Central America and the southern cone of Latin America. Most of my experience has been with Mexican nationals originally from the Western mid-southern region of Mexico encompassing the states of Durango, Zacatecas, Nayarit, Jalisco, Guanajuato and Michoacan (Immigration Forum, 1998). The warmth, hospitality and affection, the humor and hard working attributes of the Mexican people have touched me in profound ways to bridge the gap between my whiteness and privilege. I have been moved, sorrowed, and disturbed by the discrimination and economic poverty they have endured. Witnessing the injustices they have suffered I have taken a stand to be with them, to listen to their voices, and in places where they have no voice to interpret their voices and experiences to others.

How is it that I have been able to reach this point in my life that to me is so irrevocable? As a woman religious and a member of the Adrian Dominican Sisters my life trajectory has taken me to places I could never have anticipated, both exteriorly and 
interiorly and in tandem. It has allowed me the places, experiences and education that few people can access with such freedom of spirit. The Adrian Dominicans espouse a philosophy and value of respecting the gifts of individuality and of the individual while embracing the values of community. The Dominican value of study has nurtured my intellectual curiosity and drive to understand the world. The value of mobility allows for freedom of movement to respond to the needs of the world. The value of community anchors me in Dominican companionship, friendship and a sense of common life and mission, a sense of unity in the midst of diversity. Finally, the value and experience of contemplation, one that corresponds to my natural propensity for reflection, has ignited a fire in my heart to care about the world.

Lately I have perceived myself as being a bridge between peoples of different cultures as I become ever more fascinated with diversity and with people who are different from me. I consider myself a citizen of not just a country, but also the world. All people are my sisters and brothers, and all of creation is our home. This is who I am, the researcher with one life to live, a gift to be given, and with empty spaces to receive what is given to me.

\section{Participants and Entrée}

As researcher, since 1998 I have continually established connections with indigenous immigrants and with U.S. citizens who have already established strong relationships with indigenous immigrant communities. Attending cultural events, such as the Guelaguetza festival in North San Diego County, offered opportunities to meet immigrants and their allies here as well as to observe, experience and learn about the cultures of indigenous people from Oaxaca. 
During the Fall of 1999 and Spring of 2000 I continued to network. Leaflets and an announcement in the bi-weekly Spanish language news publication, El Oaxaqueño, explained the study and extended the invitation at the appropriate time. Snowball sampling, recommended by Cornelius (1982) for use with undocumented immigrants, and direct invitations in person or by telephone to participants recommended by intermediaries and community activists, were the principal means used to access the participants in the study. Religious missioners working in Oaxaca assisted in finding women willing to share their stories, and the staff of the community newspaper, El Oaxaqueño, also assisted in gaining entrée by connecting me with their counterparts in Oaxaca City.

Indigenous Oaxacan women, Mixtec and Zapotec or other indigenous ethnic women who have immigrated to the United States were invited to share their experiences of migration and health. Twenty-two indigenous Oaxacan women participated in this binational exploration of their migration and health experiences. Twenty-one claimed Mixtec or Zapotec ethnicity, and one claimed Tarascan background as a migrant to Oaxaca from Mexico City. Ten participants live in Mexico, five along the U.S. Mexico border region in Baja California, and five are returned migrants living in Oaxaca. The other twelve live in California, eleven in southern California and one in northern California.

Participants ranged in age from 20-63, and in education from no schooling to a newly earned law degree in Oaxaca. Most women completed primary grades that they identified as three to six years of school. A couple completed secondary, equivalent to $9^{\text {th }}$ grade in the U.S. All women but two were married at the time of interview, and two were 
separated from their spouses. As sometimes happens in indigenous societies in Mexico, one woman's mother had given her away, at the age of 13 , in a prearranged marriage. Five women had returned to Mexico after several years in the U.S., and four were single at the time. The other alternated migrating with her husband. All women spoke Spanish.

\section{Data Collection}

Data collection began in the spring of 2000 on both sides of the border. Participant observation and interviews in Spanish were employed as the primary approach to data collection. The interview guide was continually adapted as data were collected, and probes emerged during the interview process to explore salient points. All but three women were interviewed in their homes. Three were interviewed in places outside their homes that allowed for greater privacy.

A bilingual Latina graduate nurse assisted me on two occasions with the five participants who are part of a small settlement community in a rural high desert region on the Mexican side of the border. The assistant followed through independently with this community twice more, continuing to collect data, and independently interviewed a participant on the U.S. side. I followed with a second interview later. Data collection also continued through the summer in the Zapotec region of the Central Valleys of Oaxaca, and resumed in the fall in the U.S. Analysis proceeded commensurate with data collection until no new dimensions seemed to be forthcoming and the data appeared to be saturated. New questions were generated during data collection to gain the most depth and expansiveness of the data possible. Meetings and personal and electronic communications with committee members were very helpful in guiding these processes. 
A digital Voice Recorder equipped with smart media cards was used to record interviews with back-up mini-disk recordings for archiving the data. The recorder voice files were transferred to the hard drive of my PC via Voice It Link software, and then transmitted to my bilingual, bicultural transcriptionist using a protected private account for virtual hard drive space at www.xdrive.com. The transcriptionist used the Start Stop Universal Transcription System software for PC based transcribing developed by HTH Engineering, Inc. (www.startstop.com). Once transmitted and transcribed ver batim in Spanish voice files were deleted from the virtual hard drive. Short voice files were emailed as attachments. The transcriptionist, whose natal origin is Mexico, also translated the transcripts or the most salient portions of transcripts into English.

The Mixtec people are highly organized by village in Mexico and are developing a pan-Mixtec indigenous identity that transcends village loyalties due to their transnational migrations and unifying activities in the formation of self help groups in the U.S. (Rivera-Salgado, 1998a, 1998b). This aspect of community organization and values contributed to the style of data collection on the Mexican side of the northern border where the Latina assistant helped with the first interview, held with a group but not as a focus group. Culturally, it was sensitive and respectful to collect this data as a group activity since at our arrival a community of women was waiting for us. We also brought fresh foods, fruits and vegetables, for them to distribute later, and some money that they decided collectively to invest in the children's school supplies.

Participants were also invited and coached to photograph scenes that spoke to them of their migration experiences. Highley (1989) introduced the notion of using photography, first used in anthropology and sociology, into nursing research and practice. 
Photography can be used as an entrée to interviews and spontaneous storytelling, as a focal point for dialogue, as text for interpretation, and as an esthetic technique for generating new knowledge and understanding of human experience (Hagedorn, 1994). Several women participated in the photography project by finding something to photograph that elicited commentary on the meaning of migration in their lives. Interestingly, some of them spoke of this experience as a collective one in which they and others might leave something behind, brave a dangerous or difficult situation, or endure risks.

The generation of additional data from participant observation occurred during an extended stay in Oaxaca during the summer of 2000 . This visit also provided the opportunity to observe and learn more of the culture and daily activities of indigenous peoples. The Abascos market on the periphery of the city is reputedly the largest indigenous market in the Western Hemisphere. I met and talked with indigenous women from the Sierra Juarez in Western Oaxaca who have been camped for three years in front of the Governor's palace in the Zocolo protesting the arrest and imprisonment of their husbands, fathers and brothers. These men have been accused, arbitrarily and without proof, of being members of the Ejercicio Revolucionario Popular (EPR) but the women maintain their innocence. This was a first hand opportunity to observe the human rights situation of indigenous people in Oaxaca.

The renowned statewide annual major festival known of the Guelaguetza, rooted in pre-Hispanic tradition, brought all 16 ethnic peoples into the city of Oaxaca for two weeks, and indigenous and non-indigenous people in from other states in Mexico. The famous Zocolo (town square) was filled with market stalls and thronged with people 
selling their wares, not only in the indigenous traditions but also much in the style of county fairs and festivals in the North. The renowned Dominican church of Santo Domingo, built during colonial times, is now a site for many cultural events and is part of the city's patrimony as the former monastery houses the largest museum in Oaxaca.

Several language schools with multi-level language training placement and cultural programs are located in Oaxaca City. I attended the Instituto Cultural for advanced Spanish language immersion and greater familiarity with indigenous cultures. I photographed the area to capture visual images of the ecological and social landscape, and I personally journaled my experiences and observations in Oaxaca during my eightweek visitation there. No people were photographed without their explicit assent, and their personal photos are not used in the dissertation.

\section{Ethical Considerations}

Prolonged contact with Latino peoples has allowed me to become conversant in Spanish. Facility with a second language is an ethical issue, as is familiarity with the cultures of participants, in my view. I addressed this by refreshing and advancing my facility with the complexities of the common use of the subjunctive tenses and various pronouns during my month long language immersion. This experience was invaluable in markedly improving my conversational ability during the interview process. Although a bilingual registered Latina nurse helped with interviewing six women, I comfortably conducted 16 interviews alone, especially toward the end of data collection. Most indigenous Oaxacan women in the U.S. have learned Spanish either as a first or second language, and those I have met have been easy to engage in conversation. 


\section{$\underline{\text { Risks and Benefits }}$}

No known risks were observed during the processes of interviewing or follow up with the photography project. Quite the contrary, participants seemed quite enthusiastic and grateful to be able to tell their stories, and we established personable relationships that I will always treasure. If there were any immediate benefits it was in the opportunity to speak, be heard and responded to. Bonding occurs when women communicate their lives to one another in sacred encounters of unconditional regard. The long-term benefits can only become known as the experiences of migration and health are faithfully represented in the dissemination of findings, and in sharing the results with participants. Modes of sharing have yet to be determined.

Storytelling in nursing has been recognized as a therapeutic and an emancipatory process that can bind people together for a common purpose. Significant human experiences are shared through the human propensity for narration. The storyteller can provide a vision of community as people, and an understanding of their history and culture (Banks-Wallace, 1998; Boykin \& Schoenhofer, 1991; Heiney, 1995;

Sandelowski, 1991). Narrative storytelling helps elicit women's own views and perspectives and allows researchers to capture the contextuality of women's situations (Meleis, Arruda, Lane, \& Bernal, 1994).

For indigenous women immigrants from Mexico who wanted to give voice and image to their migration and health experiences, this research presented some opportunities. Sharing the collective voice of this experience with three participants during and after analysis confirmed and authenticated their collective history and individual experiences within that history. 


\section{$\underline{\text { Risk Management }}$}

All mini-disks are locked in a fire resistant safe. Media card files are deleted. I have reinforced the confidential nature of the data and secured a signed pledge of confidentiality from the transcriptionist. The research was explained to the participants before interviewing but waivers to signed informed consent were obtained on the recommendation of my dissertation committee from the Committee for the Protection of Human Subjects at the University of San Diego to obtain verbal consent. The rationale behind this procedure was to reduce any sense of threat to the participants, a recommendation made by Hautman and Bomar (1995) for ethnically diverse research participants. The consent form was read in Spanish and most did not sign but some participants who wanted to sign did sign the form. All participants' data were coded so that they were not identifiable, and they chose the fictitious names of either flowers or birds to protect their identity.

\section{Reciprocity}

Reciprocity in feminist research is appropriate. Three small research grants secured for this project have allowed for modest monetary compensation to participants for their time as an out of pocket expense. I also returned from Oaxaca with their very popular mole and gave each participant 0.5 kilos of mole. In addition, women who participated in the photography project have pictures they took. I paid for the cameras and film development, and other out of pocket expenses.

\section{Human Subjects}

The University of San Diego Human Subjects committee approved this research proposal in December 1999 pending minor annotations and clarifications. These changes 
were made immediately and sent to the Chairperson of the committee with the required memo attachment for final approval. 


\section{Chapter IV}

\section{Crossing Myriad Borders}

Crossing myriad borders represents the central dimension and perspective that focuses a coherent understanding of the migration and health experiences of indigenous Oaxacan women within the context of colonial legacies. Borders might be lines that separate, that juxtapose, that enclose, but they are also fluid and permeable. Some are social and political constructions. The legacies serve to produce and reproduce economic, socio-political, and environmental precursors as conditions that induce migration to resolve these pressures.

The indigenous women in this study have undergone and continue to undergo the crossing of multiple frontiers/borders that include geo-physical, political-legal, sociocultural, and language borders. They continually cross these borders, at times going back and forth in two or more directions over one or more borders simultaneously. They also have crossed or hope or wait to cross the borders of legality, the socio-political and historical postcolonial construct that confers legitimacy of residence in the U.S., of paramount concern to them. Health issues are inextricably woven into these movements across borders, and constitute some of their own borders.

The women participants have expressed these crossings in terms of their journeys of crossing over difficult and dangerous terrain, confronting differences in language, foods, customs, and of having to learn a multitude of new things for daily life that we 
take for granted, such as learning to use a telephone. They have also crossed into new territory with respect to Western health care delivery services, especially in experiences of childbearing, childbirth, preventive, and episodic health care. Yet, they cross back in preserving and using well-known remedies of their natal origin and national cultural experience when they are able to access and use them.

They have endured suffering, isolation and loneliness through family separations, doubts and uncertainties, and struggles to find decent living conditions, work, and hopes to re-unite with children left behind with relatives at home. They cross with each little success into a little more security, from less certainty to more certainty the longer they are here. Undocumented women live with both the fear of deportation and the hope that they will someday obtain the documents of legality that will make their lives less stressful through greater mobility and better opportunities for work, especially if their children have come.

A few women also expressed their dreams and hopes to cross back and return to Tijuana or Oaxaca someday, once they were financially able to invest in an income producing project or venture. Women with children invest their hopes in their children's future, which they see as tied to learning English and succeeding in their studies. They are determined that their children not suffer as they have. Suffering, persisting through difficulties, and overcoming adversities were inherent in crossing these myriad borders. The participants employed varied patterns of crossing the U.S-Mexico geophysical border. 


\section{Patterns of Migration}

The participants engaged in several patterns of migration northward that have been identified in the literature but that have also been influenced by the recent increase in policing apparatus and personnel at major urban centers along the border. The majority of women migrated directly from Oaxaca in a transnational pattern. A few came in a staging pattern after living and working for some years in northern Baja as farmworkers. One engages in circular migration, living part of the year as a worker in the United States with a work permit, and returning to live the rest of the year in Oaxaca. Several participants have remained in Baja California as settlers on marginal rural land, which they are slowly improving. Five have returned to live in Oaxaca. All participants negotiated health transitions before, during and after migration.

\section{Health Transitions}

Indigenous Oaxacan women have undergone health transitions in the realms of traditional practices, beliefs, new health risks, strengths and assets, self-care and the care of families, and in the patterns they establish to access health services when perceived necessary. In her ethnographic study, Bade (1994) observed that Mixtec women farmworkers in rural communities of California's Central Valley utilized both traditional indigenous health remedies as well as biomedical health care services. Biomedical health services, often in migrant and community clinics, nevertheless erected many barriers to access. She interpreted the use of transmedical health care as a form of resistance to overwhelming bureaucratic obstacles such as scheduling, childcare issues, paperwork, transportation problems, and lack of affordability. 
The indigenous women in this study revealed abilities to appraise health and illness situations, and to judge, prioritize and decide a sequence of remedies and approaches for common episodic illnesses, and for preventive measures for themselves and their families. They, too, used home remedies but a pattern of practicality emerged of picking and choosing different types of services for different types of health problems and issues of concern to them in their families. Typically, some of them also recognized they put their families ahead of themselves and sometimes neglected their own health needs. From within a pragmatic pattern of practices considerable variability surfaced. Health transitions will be further explored and elucidated in Chapter V. 
Dimensions and Properties

Context

Conditions

Processes

Consequences

Crossing Myriad Borders

Geo-Physical

Legal-Political

Socio-Cultural

Language

*Health Transitions

(*Interwoven throughout the matrix)

\section{Colonial Legacies}

Truncated Development

Racism/Marginalization

Poverty/Immiseration

Cultural dislocations

Human rights violations

Environmental degradation

\section{Thwarted Aspirations}

Economic crisis

"No alcanza" (not enough)

"Necessity of the people"

The space between

\section{Persisting}

Through Difficulties

Undocumentedness

Culture shock

Fractured families

Leaving behind

Being left behind

Learning new things

Strategizing to bring children

Enduring risky living conditions
Saliendo Adelante

Creating hope and meaning Investing future in children

Continuing the struggle 
Dimensiones y Características

Contexto

Condiciones

$\underline{\text { Procesos }}$

$\underline{\text { Consecuencias }}$

El Cruce de una Miríada de Fronteras

Físico - Geográfico

Legal - Politico

Socio - Cultural

El Idioma

*Transiciones en la Salud

(*Entrelazado a través del matrix)

\author{
Herencias Colonial \\ Aspiraciones Frustradas \\ Crisis Económica \\ "No alcanza" (not enough) \\ "Las necesidades del pueblo" \\ El tiempo de espera \\ Desarrollo truncado \\ Racismo/Marginación \\ Pobreza/Miseria \\ Dislocación cultural \\ Violación a los derechos \\ humanos \\ Degradación del medio ambiente
}

Persistir

a través de las dificultades

La falta de documentos

Choque cultural

Familias fracturadas

Dejar a la familia en el pueblo

Quedarse atrás en el pueblo

Aprender nuevas cosas

Estrategias para traer a los niños

Tolerar condiciones de vida riesgosas
Salir Adelante

Crear esperanza y sentido

Invertir en el futuro para los niños

Continuar la lucha 


\section{Colonial Legacies and Genesis of Migration}

Most migrants from regions of the world that were once colonized by another country do not conceptualize their reasons for leaving home in terms of colonial legacies. They do not generally think of ongoing neo-colonial foreign interventions colluding with national elites that obstruct their struggles for authentic development. Oaxacan indigenous women articulated individual and complex reasons for leaving Oaxaca while recognizing that they share these conditions with their Oaxacan friends, neighbors, and companion immigrants (paisanos). They exhibited varying levels of political understanding and awareness, and a high degree of agency.

Agency points to a core of psychological health and resolve that contributes to the ability to persist through adversity to reach long-term goals. Interestingly, an unwritten assumption that poverty stricken people are so caught up in survival issues of everyday life that they are unable to think of the future was challenged by the goal directed activities of the participants. The women's thinking in this study, and the slow but steady advances of long-term resident immigrants defied this assumption. They demonstrated a capacity to think ahead, to engender dreams, and a tenacity born of hope.

Most women made their own decisions to migrate north. More than half came as single women, including a couple who crossed over for economic reasons and to flee former partners who harassed them. Some who accompanied their spouses or came to join their spouses played a major role in that decision as they were determined to reunite their families whether they stayed home or came north. Until the recent advent of feminist investigations, studies of migration have been gender biased and assumed that women follow their spouses, like inert appendages, without exploring the thinking nor 
decision-making capabilities and actions in women (Zlotnik, 1994). But women also have hopes, dreams, abilities and aspirations for improving their lives and their families' lives. Migration became a form of problem solving to try to fulfill their dreams and aspirations, which their conditions of life at home do not allow.

\section{Thwarted Aspirations}

The perceived conditions triggering northward and cross border migration for most of the women in the study were their inability to fulfill basic human aspirations. These conditions are a legacy of Mexico's colonial history and the way colonial power relationships have been reproduced by elite groups of people to maintain privilege, power and domination after political independence from the colonizing country (Ashcroft et al., 1998). Not surprisingly, most of the women identified economic necessity, poverty, or lack of economic resources necessary to fulfill normal human impulses to care for families, to educate themselves further, or to avoid stagnation as their reasons for leaving their Oaxacan communities.

\section{No Alcanza}

Participants often referred to the economic crisis and to economic deprivation as "no alcanza", ("it's not enough") and "es la necesidad" ("it's a necessity") into their assessment of resources for life in Oaxaca. Although this discourse is not strange to citizens of the host country, it often gets lost in the fog of anti-immigrant rhetoric and scapegoating at their apogee during economic downturns in a host country. Indigenous Oaxacan women used powerful language to describe the severity of life in their communities of origin and to explain their reasons for leaving home.

- Yo no puedo vivir en Tijuana porque como le digo allá se gana muy poquito, no alcanza.... con esta familia grande no alcanza. $\mathrm{Y}$ ya aquí pues siquiera para que yo 
coma alcanza aquí pero allá no alcanza por eso me vine para acá y conocí y se gana un poco más de dinero aquí. (Clavela)

- I can't live in Tijuana because like I said, there you earn so little money, not enough... and with this big family it's simply not enough. Here at least we can eat with what I make but there it's not enough, so that's why I came here to see if I could earn a little more money here.

Another of the early pioneers among the participants, expressed her reasons as:

- Bueno, económicamente si porque, o sea, él primero se vino mi esposo porque económicamente era muy malo. El trabajo era muy escaso y es muy poquito lo que pagan en Oaxaca. Entonces él se vino primero y yo me quedé tres años. Y en tres años él mandó que yo viniera y me vine porque pues, para estar con él también y por lo económico. (Camelia)

- Well yes, economically or whatever. My husband came first because economically it was very bad. Work was very scarce and paid so little in Oaxaca. So he came and I stayed behind for three years. In three years he sent for me to come and I went to be with him, and also because of the economics.

One participant was a returned migrant whose spouse was working in the United

States at the time of this interview in Oaxaca just before the July 2000 Mexican

Presidential election. This couple has taken turns going north. She identified the

worsening economic crisis in Mexico, and corruption, as responsible for the conditions

that drive people to emigrate from Oaxaca:

- Claro, empuja a la gente, la crisis del desempleo, la crisis de la elevación del costo de la vida. El hecho que uno de papá quiere tener algo para los hijos o por lo menos darle escuela. Y que aquí no se consigue, entonces esa crisis económica y de falta de empleo que hay, es la que hace que la gente tenga que emigrar a buscar eso que necesita para su familia. La crisis en México en vez de estar cada día aminorando, crece. En primer lugar porque tenemos gente no apta, o muy corrupta en la que maneja todos los intereses de aqui de una república, y que ellos son los que se llenan las bolsas y la pobre gente se queda sin nada. Eso hace que la gente tenga la necesidad grande de tener que salir y que no hay soluciones. Ellos prometen cosas pero no hay soluciones. Así que mientras no hay soluciones la gente tiene que seguir saliendo, no hay más. (Maru)

- The crisis brings unemployment, elevates the cost of living. We, as parents, want to provide for our kids or at least give them some education. And when one realizes that because of the economic crisis and the lack of jobs, we won't be able 
to provide for the family, that creates lots of pressure on the people and they consider migration. The crisis in Mexico, instead of improving is getting worse. In the first place, we don't have competent people. The people who rule the country's interests are very corrupt, and they are the ones who fill up their pockets and the poor people are left with nothing. This is the main reason that people leave and there is no solution. They promise but don't deliver and in the meantime with no solutions, people have to leave. There is no other way.

The irony of these insights is that they conflict with the dominant political discourse of trade liberalization, symbolized by NAFTA. The promise of reduced need to migrate that NAFTA was supposed to ensure, according to former President George Bush of the U.S. and President Salinas de Gortari of Mexico, the two architects of the accord, has never been fulfilled (Freedberg \& McLeod, 1998; Sassen, 1992). Instead, the converse is true. A recent editorial in El Oaxaqueño (Editor, 2000), a community newspaper initiative of Oaxacan immigrants in Los Angeles, held the Mexican oligarchy, the financial elites allied with the Government, responsible for recurring economic crises brought about by trade liberalization that drive increased migration.

The cost of living has been escalating everywhere in Mexico without a commensurate increase in income, and as more people are driven into poverty they are pressured to leave home. Other women also held the Government responsible for the economic desperation of the people. The words of these women, who do not get heard in the public arena, are a stinging indictment of current economic policy. As Maru added to her assessment of the causes of the Oaxacan exodus:

- TLC...el tratado de libre comercio, de importación y de exportación. Yo creo que eso viene a beneficiar a las grandes empresas que tienen medios para poder hacer ese tipo de negocios, porque, por ejemplo, ¿yo que puedo importar o que puede exportar de los Estados Unidos? Pues nada.

- NAFTA...that's the accord for free trade, import and export. I think that it's going to benefit the big corporations that have the means of making those types 
of business... because, for example, what can I import or export from the United States? Nothing.

Maru makes an oblique but powerful statement about the politics of exclusion in the realm of the economic life of Mexico by her analysis that she does not fit into this model of economics. She identifies herself as a small businessperson and a worker.

Two young Zapotec women in Oaxaca who were returned migrants identified their desire to study as reasons for leaving. At the time they left, they did not have the financial means to continue their education. One felt stuck in a dead end housekeeping supervisory job and believed that learning English would improve her opportunities to advance into a professional occupation. Jasmine aspired to have a professional career:

- Yo trabajaba en un hotel con gente de todo el mundo... en un hotel en Oaxaca de cuatro estrellas, estaba como supervisora de cuartos. Mi trabajo era mucho, trabajaba en la mañana y en la tarde. Me gusta ese trabajo es muy bonito trabajar con las personas... la comunicación, o sea, me gustaba mucho mi trabajo. Pero yo sentía la necesidad de querer hacer otra cosa, de decir - No toda mi vida voy a estar como supervisora y si el segundo paso es como de ser como ama de llaves entonces yo dije - Yo necesito aprender y si quiero estar en la recepción y quiero estar en el teléfono, en primero lugar tengo que aprender hablar inglés, mínimo inglés o entenderlo. Entonces de ahí surgió mi necesidad de decir - quiero aprender otra cosa y no quiero estar todavía la vida acá. (Jasmine)

- Before going to the United States I was working... I finished a Technical Career in administration. It was a technical career in the tourist field and I used to work in a hotel with people from all over the world... at a four star hotel in Oaxaca. I worked as a room supervisor. It was a lot of work, from morning till evening. I liked that job and it is nice to work with people...communicate with them, I mean, I liked my work very much. But I felt the need of doing something different. I would say to myself I'm not going to be a supervisor for the rest of my life, and the next step is being a housekeeper. Then I decided I needed to learn English, the basics, at least to the level of understanding it. That was the beginning, the need of wanting to learn something else and not willing to stay the rest of my life here.

A returned Zapotec migrant who learned English in her three years in the United

States as a young single woman while doing domestic work, Jasmine is now equipped 
with a law degree from Oaxaca. She was highly concerned about the phenomenon of migration, reflecting the distress of many Oaxacans over this issue, and had hopes to use her law education to address the human rights situations of emigres.

Flor, a 20-year-old Spanish-speaking Zapotec, was the youngest participant in this study, and was 16 years old when she left home. The agency of this young woman was striking. She returned to Oaxaca after three years where she worked in the Midwest, but was expressing her desire and intent to cross over again at a future time into the United States. Most of the young people from her village have gone north because they see no future for themselves at home. Flor initiated the process of migration and invited her older sister to accompany her for this reason:

- Por falta de recursos económicos fui para allá. Si lo que pasa es que yo quería estudiar acá, pero mis papás no tenían los recursos económicos. (Flor)

- Because of lack of financial means I went there. I wanted to study here, but my parents didn't have the financial means.

Flor also articulates what many Oaxacan women identified as their preference for staying home if they could aspire and realize their hopes and dreams for themselves or their families. Most of the young migrants from her village have located in a midwestern town where work is plentiful.

\section{Necessity of the People}

Ada, now settled in the United States, cogently pointed out that undocumented migrants who were deported to Tijuana by the Immigration and Naturalization Service (INS) return immediately because they cannot turn back:

- Los mandan para Tijuana y al siguiente día ya están de Nuevo. Pues es la necesidad de la gente y si la gente no hace eso no podemos regresamos sin dinero para donde venimos. Entonces ese no seria el caso porque si hubiera trabajo en 
México o otra manera de ganarse la vida. Pues allá estuviéramos... pero a eso venimos a hacer una vida major.

- They (the INS) send them to Tijuana and the following day they are here again. It's the necessity of the people and if we don't we can't return home without any money. This would not be the case if there were work in Mexico or some way to earn a living there. If there were, that's where we would be...but we come here to make a better life.

A certain conflict is revealed in Ada's perceptions, as in others. Their decisions to migrate are conflicted. Leaving the homeland would not be the preference of these indigenous immigrants and other Mexican immigrants if they thought they could meet their needs and achieve their dreams there. Flor de Nochebuena (Poinsetta) said it this way:

- Quieren regresar a su país pero temen para regresar a su país porque en Oaxaca esta mal. No hay trabajo, aunque la gente quisiera dedicarse allá... yo no sé que hace el gobierno, yo no sé que.... Porque dice que van a hacer mucho por los mexicanos... pero que han hecho... lo que los mexicanos necesitan es el trabajo... teniendo su trabajo en su país ellos no sé van a venir acá, pero muchos se vienen por trabajar, por falta de dinero... entonces... eso es lo que tiene la gente mexicana cuando se viene aquí para vivir, me iré a mi país, o no me iré... porque para regresar, como? Si no es fácil.

- They would like to go back to their country but they're afraid because in Oaxaca it's so bad. There's no work even though the people would like to devote themselves to work there. I don't know what the government is doing... what have they done yet? Because they say they are going to do so much, but what the people need is work to earn some money... if they had work there they wouldn't be coming. What happens to the Mexican people who come here to live is they wonder if they should go back or not, but why go back? No, it's not easy.

None of the reasons given for coming north and crossing the border with or without papers is surprising. The grit, the courage to risk, and the intelligence to plan, uproot and venture forth into an uncertain and unfamiliar place is extraordinary and amazing. 
Since a sufficient economic base is crucial to the growth, development and health of individuals, families and communities, it lies at the heart of the thwarted aspirations that compel these migrant women to leave home and cross over many borders in an effort to achieve their human aspirations. That health status in general is associated with socioeconomic levels is well known and documented (Winter et al., 1993). Nurses are well acquainted with the relationship between poverty and adverse health events in both individuals and communities (Hegyvary, 2000). Inability to fulfill human aspirations can be linked to elevated health risks because of a lack of resources for healthy conditions of life.

But the proactive decision-making that compelled these women either alone or with spouses, to leave their Oaxacan homeland, even if reluctantly, could be interpreted as a global health resource within them. Nonetheless, migrants compelled to leave home because of extreme poverty or for environmental reasons are not officially recognized as economic or environmental refugees. They occupy a "space between" voluntary and involuntary migration.

The Space Between

The discursive spaces of migration in politics and policies leave no room for conflictive decisions to leave home. The politics of migration have dichotomized this phenomenon into voluntary and involuntary categories that cover the patterns extracted from the literature. The postcolonial binary nature of this limitation becomes obvious when migrants talk about the conditions under which they leave. It creates a class of excluded others who do not qualify as refugees from danger or persecution, nor as the 
highly educated immigrants often admitted to rich countries for their skills, nor as authorized family members.

In spite of the agency within these indigenous women they are located in a space between voluntarily and involuntary migration. The increasingly restrictive immigration policies of affluent host countries make no provision to recognize this dilemma and force them into a clandestine life without documents. Current U.S. policy results in criminalizing responsible normal behavior, and in violating fundamental human rights (Alvarez, 2000; Huspek, 1998; Kahn, 1997). Maybe that is one reason the border crossing surfaces as such a critical migration and health experience in the stories of the participants.

\section{Crossing the Geo-physical Border:}

Most women in the study spontaneously recounted their stories of crossing over, a pivotal event in their migration experience. Crossing the geo-physical border held great significance for them. It represented a hard won victory, a barrier successfully negotiated, a danger surmounted.

Some of the dangers they identified that are not in the literature are bone fractures from the arduous climbing and descending, the almost paralyzing body aches suffered at the end of the journey as they recovered, "demonios" (bad spirits) who could steal children who are crossing, and having one's body eaten by coyotes (animals). The border crossing is a common topic of conversation in the Oaxacan community precisely because of its significance for health, life and death as the following perspectives reveal:

- Estaba feo, es peligroso y todo... pues como uno quiere ir para allá, pues va decidido a lo que sea. Tuvimos mucha suerte porque pasamos rápido pero caminamos mucho y estabamos con hambre y no teníamos agua. Yo iba a cruzar 
un camino y se me enterró una espina en el pie, y yo nada más llevaba los tenis, se me enterró... (Flor)

- It was very ugly and very dangerous and all that... but if you want to go there, you have decided to encounter anything. We were very lucky because we crossed very quickly but we walked a lot, we had no food or water. I was going to cross a road and a thorn went into my foot. I was only wearing tennis shoes, it went in...

Participants were highly aware they were unwelcomed into the United States.

They are mystified by this stance which stands in stark contrast to their cultural values of hospitality and sharing the little they have.

- El paso como eso tan difícil... y como corre la gente, y como les sueltan los perros para que los agarren, y como vienen los aviones bajitos, es muy dificil, pero aun así pasa la gente (Asucena)

- We know how difficult is the crossing... how people run and how they (INS) let the dogs loose to catch them and how the airplanes fly really low... is very hard, and yet people continue crossing... I don't know how they dare.

- Ven su sufrimiento, se mueren de sed, de hambre, de calor, de frío, de tantas cosas sufre la gente. $Y$ ya ve que cuando se cruza la gente en tiempo de lluvias, vienen con frío y mojándose de la lluvia, y así vienen luchando... y en tiempo de calor, imagínese, vienen muriéndose de sed, al rayo del sol, y todo eso es lo que ellos ya no quisieran sufrir y ellos platican eso porque ellos vieron su sufrimiento. (Flor de Nochebuena)

- They (the community) see their suffering, that they die of thirst, of hunger, of heat, of cold, and of many things the people suffer. And when they cross during the rainy season, they come struggling through the wet and cold. During the summer, imagine, they come dying of thirst because of the sun's heat, and they suffer from all these things. That's why the people talk about it because they see their suffering.

The geo-physical border also symbolized a leap between two worlds, and entry into new and alien territory. It represented the moment when life became dramatically altered in a strange new terrain, a stark if not hopeful moment of transition. Likewise, however, it constructed these women as "unauthorized" persons, as politically, legally, 
socially, racially, and culturally unwelcomed and marginalized although their labor was surely needed and welcomed.

\section{Crossing Political-Legal Borders}

At the time of entry into the United States none of the participants had documents that legalized their status. Many had obtained legal status by the time of the interview. Some were waiting for "papeles" (papers), and some were waiting in a state of legal limbo for the next opportunity to apply for legal status either through a child citizen old enough to petition, or a spouse awaiting citizenship, or through a national amnesty program. The possibility of apprehension by "la migra" (border patrol) was an everpresent specter that constrained their mobility, work options, and therefore their income and ability to access health care because of affordability and the need to keep as low a profile as possible. Undocumentedness emerged as the overriding sub-dimension of crossing the border without papers.

In her exploration of the concept and its relevance to nursing Messias (1996) contends that little has been written of undocumentedness. Undocumentedness is the state of not having certain legal papers that prove the right to reside in the United States. Historically this proof has been required since Congress passed the first immigration law in 1924. The women in this study spoke freely of their status and how it affected them.

\section{Undocumentedness}

Undocumentedness affected the quality of their lives by producing fear and a state of hypervigilance that made existence stressful and more difficult. The mental health effects of undocumentedness have not been studied for either short term or long-term health implications but emerged as a health issue because of its social impact. That 
prolonged stress negatively affects immunity is well known, but women who might have chronic conditions or preliminary, early, or curable stages of cancers such as cervical dysplasias or an in situ neoplasm, carry an elevated risk if they don't access available health services such as community clinics or public health departments.

Being undocumented can complicate already increased health risks due to other variables such as affordability, accessibility, knowledge, and willingness to seek care. Most women in this study identified undocumentedness as a major and overriding concern that influenced their thoughts about seeking health care, or that complicated their lives with fear. Their distress about their lack of legal status is evident, although not universal among all women without papers:

- El día que me sentía muy mal, le dije a mi cuñada, me siento muy mal. Dijo, sabes que el doctor es muy caro, mucho, mucho muy caro. Me dijo una compañerita, vaya ahí le van a ayudar. Bueno le dije pero es que no tengo ni un papel, yo no soy residente aquí, que tal si... tenía miedo porque dije, si yo voy ahí, y que tal se me agarra la migra... y entonces me puede deportar a mi país, entonces sentí miedo, (Colibri (Hummingbird))

- One day I was feeling very bad and I told my sister-in-law how badly I felt. She told me the doctor was very expensive. Then a friend told me to go to this place where they would help me. But I told her that I didn't have even one paper and I am not here legally. I was very fearful and I told her what if they ask me for my papers when I go and immigration comes to get me? They could deport me back to my country, and so I was very afraid.

- Me da miedo a veces salir... salgo cuando es necesario salir, si no, no. Se siente muy impotente, no puede hacer nada. (Violeta)

- I'm afraid to go out and only go when it's necessary. If it's not necessary I don't go. I feel impotent, like I can't do anything.

One woman believed she was protected from immigration agents by one of the saints whose images she carried in her wallet. Another woman who has been in the U.S. 
for about ten years attested she isn't afraid and viewed her safety from immigration agents as a matter of God's will:

- Depende porque yo no tengo miedo ya de Dios... si Dios así lo dispuso que me lleven pues que me lleven y si Dios no quiere pues nimodo aquí sigo estando. (Siempreviva)

- It depends, because I'm not afraid since if God is disposed that they take me then they will take me, and if God doesn't want them to get me then I'll keep staying here.

Participants talked about other problems and health consequences that arise because of undocumented status, such as easy exploitability. Immigrants without papers are less likely to speak out against malfeasance, absentee landlords who never return deposits on apartments or fail to maintain them properly, medical malpractice or neglect, or other injustices that ultimately affect economic security, health and well being. Both exploitation and suppressed voices can also be part of the experience of undocumentedness as the following participants recount:

- No le pagaba, nada mas le daba como para ayuda. Estabamos ahí y lo que le pagaban era muy poco... como para podernos mover nosotros a otro lado y yo estaba muy deprimida. (Ada)

- He (spouse) wasn't paid, only enough to eat, a little help. We were here but were paid very little, and not enough to move. I was very depressed.

- Cuando la persona es indocumentada tiene más temor a veces... porque dice, a lo mejor van a llamar a la inmigración si yo digo algo. Por eso es el temor que no hablan porque tiene miedo de hablar... (Camelia)

- When a person is undocumented they are more afraid to speak up. They think that if they speak up (about some wrong) someone will call immigration. It's fear that keeps them from speaking.

Undocumented status also requires that women who have immigrated to find work must often resort to secrecy for self-protection, using fictitious names and 
identifications (chuecos) to find employment. As a property of marginalization (Hall et al., 1994), secrecy is a mechanism for "passing" (Goffman, 1963, p. 73) to maintain a hidden identity. Work options were still limited, however, since some employers scrutinized papers more closely than others did.

The undocumented women in this study knew from the community grapevine where they could find work and the places to avoid. Many were engaged in domestic work such as cleaning houses, and a few were working in light manufacturing for wages barely above the minimum. Many had once worked in the fields as agricultural workers. Since the most recent revision of immigration law in the 1996 Gingrich Congress, undocumented migrants discovered with falsified papers may be subject to prosecution, even when they are otherwise law abiding hard working people who contribute to the economy and pay taxes.

A long-term effect of working without an authentic social security number, however, robs the women of their potentially earned social security benefits, further threatening their future health by diminishing their possible future income. Undocumentedness works against the most vulnerable population of all, women who generally live longer than men do. Understandably, the greatest hope of women in this study who had not yet achieved a documented status was that they would someday qualify to legalize their status. Women who had achieved legal status remarked on the freedom it brought them, even if they began to shift their worries to other issues:

- Más difícil es vivir en los Estados Unidos seria lo de estar indocumentada...en mi caso es diferente porque ahora me hice ciudadana y no tengo el temor. Cuando no tenía, es miedo de que hoy esta aquí en los Estados Unidos, mañana puede estar en Tijuana. Porque usted sabe que no esta libre. Esta en un país en donde esta libre de hablar y de todo lo que tiene aquí de sus leyes...pero no es libre para andar porque lo puede agarrar la inmigración. (Camelia) 
- The most difficult thing about living in the United States is to be undocumented. In my case it's different because now I'm a citizen and I'm not afraid. But when you don't have papers the biggest fear about being here is that tomorrow you could end up in Tijuana. You know that no one is free without papers. In this country the laws allow you to say anything you want but you're not free to go wherever you want because immigration can get you.

The issue of documented status is highly charged, political and complex, and this participant perceived the contradiction between free speech and unfree mobility. A cadre of undocumented workers has always been acceptable to the United States Congress according to Calivita (1995). "Back door" (p. 236) immigration serves the interests of capitalism, the predominant global economic model at this moment of history, by maintaining a safe supply of economical labor that can, when desirable, be deported.

Fear of deportation inhibits union organizing and enables wage depression. Nagengast (1998) believes that immigration officials become, in effect, labor enforcers in an unofficial but real capacity. Becoming documented then is in the best health and wellness interests of immigrant working women, but is often a long process that can sometimes take many years even when eligible. For some women a major asset perceived to improve their chances of someday obtaining papers, and better work, was the task of learning English.

\section{Crossing Language Borders}

Inability to speak or understand English upon arrival in the United States constituted a major dimension of culture shock, but over the long term looms as a major dimension of crossing myriad borders because of its constancy in the lives of non-English speaking immigrant women. Therefore, it is considered separately in this section with its own sub-dimensions of learning English, relying on interpreters, and language difference 
and discrimination. Initially, the language barrier produced a profound sense of isolation, imprisonment, relational constraint due to language differences, and disorientation to new surroundings.

- Llegando al norte, allá en los Estados Unidos sentí como que esta uno metido, como que esta uno encerrado, como que esta en algo que no puede moverse. Para salir, hay que saber como pasarse uno una calle, saber bien como saber las calles, como todo esta en inglés, como le hace uno. Todo eso es muy dificil (Acusena)

- When I arrived up North in the United States, I felt enclosed, like in a cage, like being in a place unable to move around. When you go out, you need to know how to cross the streets, to be familiar with the streets because everything is in English, it's difficult to get one's bearings. Everything was difficult for me.

- "Los Tigres de Norte" estaban sacando una canción que decía que los Estados Unidos era una jaula de oro, pero no dejaba de ser una prisión, para nosotros los adultos, pues, porque para los niños aprendían el inglés y ya se creían que eran de Estados Unidos. (Guillermina)

- "Los Tigres del Norte" had a song that said that the United States was like a golden cage, but nevertheless a jail, for us, the adults, because for the children, they could learn English and they could feel part of the United States.

\section{Learning English}

For the most recently arrived participant, the language difference entombed her in a sense of deafness and silence but also motivated her to begin English classes shortly after her arrival. Learning English was symbolic of her determination to make sense of her inchoate new world, and bridge as best as possible a gulf of incomprehensibility and invisibility created by language differences:

- Aquí estamos en un país, para mi, como de los mudos y de los sordos...porque le hablan y usted no entiende nada... y los sordos, porque no, tiene que quedarse en silencio por muchas veces... Voy a la escuela y les pongo atención. Yo no sabía contar y aprendí del uno al diez. Muy importante... eso aprendí, a veces me equivoco porque a veces se me olvida el cinco...one, two, four, five, six, seven eight nine que es nueve, ten que es diez... hasta aquí aprendi. (Colibri) 
- Here we are in this country and for me it's like being deaf and dumb because people talk and you don't understand anything, and you have to remain silent most of the time. I'm going to school and I pay attention. I didn't know how to count and I've learned from one to ten. It's very important, although sometimes I forget the number five...one, two, four, five, six, seven, eight, nine, ten... up to here I've learned.

The inability to communicate in English also surfaced as a perceived impediment to better work opportunities. Some of the earliest arrivals have mastered some English speaking ability, and an understanding of the language even if they are more comfortable using their native language. All women with children intensely wanted their children to learn the language as a tool for empowerment, and they defied the stereotype of immigrants resistant to learning the dominant language of a host country. Instead, they viewed learning English as essential to succeeding, progressing, and defending themselves against exploitation. This view does not necessarily compromise cultural identity or even mean assimilation, but appropriates from the dominant culture a means of oppositionality to those features of the host country perceived as oppressive. Some women viewed learning English as a non-negotiable imperative for themselves:

- Entonces yo creo lo que uno tiene que hacer aquí es sobrellevar las personas, pero lo importante, importante es aprender hablar este idioma, porque si uno llega a este país y hace, o sea... no hace el intento de aprender este idioma, es muy difícil porque siempre, siempre... las personas lo tratan de hacer de menos a uno, siempre... no hay como aprender a hablar este idioma, donde quiera que usted que va, donde quiera se puede defender. (Paloma)

- I think that what's important here is to relate to people, but what is most important is to learn the language. If one comes to this country and has no intention of learning the language it's so difficult because people always treat you as less. There's nothing like learning this language because wherever you go you will then be able to defend yourself.

However, complicating the ability to learn English for a number of these first generation immigrant women were their very complex lives as undocumented working 
women with family worries, responsibilities, and limited opportunities, time, mobility, and money. Some viewed English as necessary to avoid discrimination in hiring, especially if undocumented:

- El que sabe ingles la hace también porque es el que sabe, aunque no tenga papeles. Pero el que no sabe y no tiene papeles, la discriminación que no le dan trabajo. Y hay mucha gente así, sin trabajo también que no los aceptan, pues por lo mismo de los papeles. (Acusena)

- Those that speak English are going to make it even if they don't have papers. But those that don't speak and don't have papers are discriminated against and don't get job offers. And there are many like that, without a job, who are not hired because of the same thing-not having papers.

In other situations, women had no choice but to rely on interpreters in critical situations. One important venue requiring interpreters for all women at some time, and most women still, is that of the health care setting.

\section{Relying on Interpreters}

Lack of English language facility also presented communication barriers in the health care setting that frustrated the participants, even when interpreters were available. One woman recommended interpreters for clients who spoke indigenous languages, but opinions differed on the use of interpreters in the health care setting because of skepticism regarding the accuracy of interpretations rendered:

- A veces tiene interpretes pero ellos mismos no dicen exactamente lo que uno quiere decir. Entonces pasa eso que no encuentra uno la palabra para decirlo, si uno quiere traducir entonces uno no puede decir las palabras que uno quiere exactamente. (Camelia)

- Sometimes they have interpreters but they don't say exactly what one wants to say. So what happens is that they can't find the exact word to say what you want and so the translation doesn't say exactly what you mean.

Another participant believed the clinics need interpreters also for indigenous immigrants who speak their indigenous language. She believes that interpreters are 
essential for explaining important procedures such as cervical cancer screening or breast exams. Women from remote regions of Oaxaca may never have heard of or are too embarrassed to seek these preventive measures without knowledge of them and understanding their importance. A bilingual Mixtec-Spanish speaker herself, this participant essentially identified a need for outreach and health education that is geared linguistically and culturally to the population because she understands the world of origin and the new world of the immigrants:

- Haya una persona ahí que pudiera interpretarlos, que haga entender a la gente... como para hacer un Papanicolau o para hacer un chequeo de los senos, pues que no tengan miedo, que no tengan pena, porque mucha gente... les da pena eso. (Ada)

- There should be a person there who would be able to explain what people need to know, such as how a pap smear is done, or how to do breast self exams... and to help them not be afraid or embarrassed, because a lot of people are mortified about this.

These conflicting views regarding the utility of interpreters in the clinical setting touch on the dilemma of language differences that are encountered by immigrant clients when they do not speak the language of providers or the clinic culture. Hatton's (1992a; Hatton \& Webb, 1993b) research from interpreters' perspectives concludes that interpretation and translation are distinct phenomena. Effective interpreters collaborate with health providers and understand the social worlds of both client cultures and clinic cultures that influence the meaning, and therefore the accuracy of information transmission. Hatton recommended research from the client's perspective, a need that is corroborated by these women's differing insights. But participants also identified the need for clinicians and clinic staff to speak some Spanish, and regarded this effort as a sign of sensitive health care responses. 


\section{Language Differences and Discrimination}

An issue of concern to Oaxacan immigrant leaders is the suppression of their indigenous languages due to discrimination from others. Many bilingual indigenous language-Spanish speakers suppress their indigenous tongues in public and have often stopped teaching it to their children. Therefore, children are losing a precious cultural heritage, diminishing and impoverishing the global ethnosphere (Wade Davis, Personal Communication, January 20, 2001). Efforts to encourage people to use their indigenous languages and keep them alive are being promoted by leaders of indigenous Oaxacan self-help groups. One bilingual participant claims her Mixtec language with pride and resists this subtle pressure to hide her indigenous language:

- Veo a las personas de mi raza a veces les digo, a hablas mixteco y me dicen si o no, porque muchas veces no quieren hablar o muchos no saben. Si saben nos ponemos hablar y platicar. Mi esposo también y a mi no me da vergüenza, verdad de decirle de donde soy y que es lo que hago y nada de eso porque eso no me lo va a quitar nadie, no? (Ada)

- I see people of my race and sometimes I ask them if they speak Mixteco and they tell me no because they don't want to admit it, or because they don't know. If they know we can talk. Neither my husband nor I are ashamed because the truth is that no one can take from me my origins and identity.

Children also endure discrimination, mostly from other non-indigenous, mestizo Mexican children at school. "Oaxacos" and "indios" are epithets used in name-calling and derogatory teasing, because of their short stature and dark color (Kearney, 1998).

Under these circumstances children also tend to reject their native language as they learn English unless they receive positive affirmation for their bilingual or trilingual abilities. Language is a major feature of culture, and transmits the cognitive map of culture from one generation to the next, and therefore of an important source of identity. 


\section{Crossing Cultural Borders}

Entry into the United States from Mexico induces varying degrees of culture shock. The Random House Dictionary (1996) defines culture shock as "a state of bewilderment and distress by a person who is suddenly exposed to a new, strange, or foreign social and cultural environment" (p. 488). Women who migrated directly from Oaxaca were more strongly jolted by the vast cultural differences between the United States and their very indigenous homeland. Migrant women who had lived in northern Mexico had had time to acclimate to some differences since northern Mexico, with its proximity to the United States, has developed a distinct border culture in which overlap between the two countries is a prominent feature.

Dimensions of culture shock expressed by participants were an overwhelming sense of isolation, loneliness from leaving family members behind, initial disorientation, and doubts about whether to stay or return home. The fracturing of families was the most salient dimension exacerbating culture shock for migrants who left family behind, and separation for family members who were left behind. Culture shock was especially compounded when women left children behind, and when they were the earliest pioneers among Oaxacan immigrants without established ethnic communities to offer support. Additionally, participants recalled their need to learn many new things, and spoke about changes in food, water, and other customs that had considerable meaning for them.

\section{Fractured Families}

Indigenous Oaxacans' social structures are communal and familial. The values of indigenous people in Oaxaca are oriented to community service (tequio or cargo) and cooperation for the good of the whole (Monaghan, 1995; Rivera-Salgado, 1999). When 
indigenous Oaxacans migrate the comfort and they leave behind the support of community and family, which adds to the sense of alienation and isolation, especially pronounced in the experience of early pioneers. The formation of Diasporas throughout the United States exponentially multiplies the numbers of pioneers undergoing this experience, making it highly significant for mental and emotional health. Participants missed family and important rituals, such as funerals, but separation from children was especially egregious to them.

\section{Leaving behind}

Women told poignant stories of having to leave children behind, parents behind, of enduring difficult living conditions, and of strategizing to bring their children across the border once reasonably settled and able. They suffered from intrusive thoughts of their children in Mexico, depression, sadness, and loss of appetite during this period of separation. These difficulties, sorrows and suffering are sharply etched in their memories but the most recent arrival was living through the experience when she participated in the interview.

- Muchos peligros... porque, yo no nada más tengo una hija. Tengo dos hijos más, pero una hija va a cumplir quince años. Ella no puedo venir. Ella se quedo en... muy peligroso, porque hay que correr mucho... hay lugares que hay que correr, hay lugares que hay que caminar... entonces es muy dificil... pero, pues Dios nos ayudó y llegamos aquí... (Colibri)

- There are so many dangers. I only have one daughter with me. I have two more children in Mexico, one who will be 15 years old. She couldn't come because it's so dangerous with all the running and walking. It's so difficult, but God helped us and we arrived safely.

- Atrás deje a mi hijo, José, él tenía cinco años y se quedó con mi mamá y mis hermanos, se quedó él porque no podía traerlo... porque no sabía si yo iba a poder pasar y este. Yo sufría mucho, por un año porque no lo miraba y pensaba mucho 
en él. Si, pensaba mucho en mi hijo y que tenía que ir a traerlo, pero aguante un año de que él estuviera lejos. (Camelia)

- I left my son, Jose, who was five years old. He stayed with my mother and brothers because I couldn't bring him. I didn't know if I would be able to get across. I suffered for a year because I couldn't see him and I thought of him constantly, and wondered how I could bring him.

Another participant talked about how she sent money home but felt it was not the same as being able to see her children in person. She suffered a loss of appetite and thought of her children when eating, wondering if they could eat too.

- Le mandaba yo dinero a Tijuana, pero yo no me sentía a gusto porque no miraba a mis hijos. Llegaba yo aquí solita, no hay nadie y pues a veces hallo dinero, compro comida. No me siento a gusto comer porque no están mis hijos aquí. $A$ lo mejor yo como pero mis hijos no comen, y eso es lo que más me dolía. (Clavela)

- I sent money to them in Tijuana but never felt happy because I couldn't see them. I came alone without anybody and was able to save some money and buy food, but didn't enjoy eating because they weren't here with me. Here I am eating and maybe my children aren't eating, and this hurt me the most.

Some participants still have children in Mexico, indicating they suffer from feelings of guilt or loneliness. Yet, they fear the risk of bringing them across in the current border environment. One single mother handles her dilemma by focusing on studying English and working toward her high school equivalency diploma (GED) in the hopes of bettering her situation and helping her children in this way. They hope for papers to travel freely between the two countries. Most women are or have been proactive in plans to reunite their families by finding ways to bring their children across the border.

\section{Strategizing to Cross their Children}

Participants identified the uncertainties of the migration experience as reasons for leaving children in the care of relatives, to prevent their children from suffering from 
possible hunger, lack of shelter, and the dangers of crossing unknown and dangerous terrain. Becoming familiar with the United States, gaining some economic security and a place to live were prerequisite to bringing their children to the U.S. Women who eventually found creative ways to bring their children across acknowledged that the danger has increased for those who want to try reuniting families, and the cost has escalated due to the dangers. Participants employed spouses or other relatives, or known dependable coyotes to bring children across:

- Aquí estuve dos años, después me fui a recoger a los niños porque los deje ahí en Oaxaca con la mamá de mi esposo. No sufrieron porque mi mamá ya había arreglado el permiso...entonces mi mamá fue por ellos y se los trajo.

(Flor de Hortensia)

- I was here for two years and then I went to get my children because I had left them in Oaxaca with my mother in law. They didn't suffer because my mother had gotten her papers in order and so she was able to get them across.

Some women also spoke about the effect of migrant spouses on their lives. When they are left behind the family also suffers. This aspect of migration is rarely considered quite possibly because it is women who are most affected, and many migration studies give emphasis to monetary remittances home rather than to relationships.

\section{Being left behind}

Women who had been left behind by spouses before migrating themselves struggled with issues of separation, heavy burdens of child rearing responsibilities, and children who began acting out without a father's presence. These burdens were expressed principally as having to work for low wages in Oaxaca to supplement the money sent home from the U.S., as acting out behaviors arising in children who missed their fathers, as an increased work load in attending to children's needs, and as more work associated with management of the household and possibly the "milpa" (planted field). They 
indicated that their spouses played important roles in childrearing in their families, and that family separation is of crucial concern to their Oaxacan communities.

- Si necesita una ayuda en la escuela, pues solo está la mama. Si están enfermos, pues no está el papá solo la mama. Si necesitan algo, no está el papá, nada más la mamá, entonces solo es la mama. El papá no existe. Se separa mucho la familia y las gentes... y la familia porque los hombres... los maridos se vienen porque quieren mandar económicamente para México... dinero. Pero las mujeres allá están solas con los hijos... y a veces como no tienen un papá entonces, los niños no están bien, están rebeldes y eso... porque no está su papá. (Camelia)

- If they need help in their schoolwork there's only the mother to help. If they are sick there's no father, only the mother. If they need something there's no father, only the mother. For them, the father doesn't exist. Many families are separated like this without the men. The men leave because they want to send money home to Mexico. But the women are left behind alone with the children. Sometimes the children become rebellious and hard to manage because they miss their father.

According to the Mexican Government, Mexican émigrés remit about 6 billion

dollars annually to their families in Mexico (Migrantes, 2000). Nevertheless, participants identified as more important the health aspects of emotional, spiritual, and psychological components of family separation that are rarely addressed in migration literature of the social science disciplines:

- Se van solucionando problemas económicos pero a nivel de afecto, este, si se perjudica. Como por ejemplo, yo lo veo con mi niño, a veces entra en etapas de irritabilidad, a veces esta violento, agresivo, a veces lo veo triste y es la falta, la convivencia con el papá. No es lo mismo que hable por teléfono cada ocho días o cada quince días, a que lo este viendo. Lo mismo pasaba cuando yo no estoy... y los hijos manifiestan de manera agresiva el descontento que tienen porque no esta la pareja junta. Entonces es una manera de demostrar que no están conformes de que salga la mamá o el papá. Así que a nivel emocional, si les afecta también... como a uno porque, yo estoy sola ahorita y me hace falta el apoyo de mi esposo. Yo tengo que enfrentar todos los problemas que llegan como hombre y mujer o cuando él esta, es lo mismo. (Maru)

- The economic problems get resolved but the emotional part gets affected. For example, I can see it with my son. Sometimes he goes into irritable phases and sometimes he is violent, aggressive, and sometimes he's sad and this is as a result of not being able to share more time with his father. It's not the same talking on the phone every 8 days or 15 days, than being with him. The same thing happens 
when I'm not here. Children behave aggressively because they don't have both parents with them. It's a way of showing that they are not happy because mom or dad eventually have to leave them. So, at the emotional level they suffer a lot, the same way as we do. Let's say, now I'm by myself and I need my husband's help. I have to confront all the problems as a man and as a woman and it's the same way when he's by himself.

The disturbing messages of the effects of family fracturing on their members are heightened in the contradiction that migration is itself exacerbated by U.S. neo-liberal economic policy that has international repercussions (Aviles, 1999). Additionally, Oaxacan and other Mexican families are suffering the tragic loss of migrating members in increasing numbers as the death toll mounts at hazardous border crossing points.

Undocumented immigrants who successfully cross face many uncertainties. One of them is finding shelter, and the other is finding work. These migrants do not have independent transportation and often live in conditions of makeshift shelters in canyons or on ranches, or in crowded apartments that present risks to their health and lives.

\section{Enduring Risky Living Conditions}

Many women lived in makeshift shelters outside in the canyons or in tiny cramped quarters at the beginning of their new lives in the U.S. Their initial living conditions surfaced risks to health and life that are generally not considered in clinical settings. Anxiety about finding shelter and having enough space to live decently with electricity, cooking space, and indoor plumbing and water were concerns articulated by participants. They also recounted experiences that illustrate dangers of fire, snakes, communicable diseases, and psychological lack of space from overcrowding with strangers:

- En ese departamento vivía mucha gente. Eramos nosotras dos mujeres, y otra muchacha y había como ocho o diez hombres... viviendo ahí. Entonces era incomodo para nosotras estar ahí, dormíamos en le closet, los demás en la sala, 
los demás en un cuarto, los demás en la cocina. Entonces era horrible, era... feo (Jasmine)

- That apartment was very crowded...the two of us and one other girl and like eight or ten men were living there. We were very uncomfortable, we had to sleep in the closet, others in the living room, others in the bedroom, others in the kitchen. It was awful, really nasty.

- Aahí en el monte había mucha gente de Oaxaca...familias y con niños y todo como dormíamos en el cerro yo pensaba que a lo mejor una cascabel me podía morder. Porque unos días antes, la vecinita de nosotros le salió una víbora. Entonces pues yo me quede con ese temor de que un día de estos iba a amanecer muerta por una culebra. (Guillermina)

- In the hills there were lots of people, whole families. We saw that the house was built under the ground, like the beavers, under the ground. Maybe because I was sleeping right on the hills... and all the time they showed us the rattlesnakes that they killed. So I always slept afraid thinking that one of these days I'm going to end up dead bitten by a rattlesnake.

One participant talked about two people who burned to death while living outside

in a makeshift wooden shelter in a field. Another participant talked about her own terrifying experience with fire when she returned from a rare afternoon away from the house with her father and brother. This family had no electricity and used gas stored in tanks for cooking and heating the house in winter:

- Al principio, pues cuando yo llegué vivíamos en un rancho. Cuando viviamos aquí dos años y medio se nos quemó la casa donde vivíamos. Cuando regresamos en la tarde ya nada mas ceniza había y los bomberos estaban ahí. Desapareció todo, se quemo todo. Cuando llegó mi esposo no estaba yo, dice que se asustó pensó que nos quedamos ahí todos adentro, pero no.... hasta Dios quiso que ese día mi papá y mi hermano no trabajara y llegaron por mi... si no yo me iba a morir ahí yo creo. El fuego empezó...explotaron los tres tanques de gas. (Violeta)

- At first when we arrived we lived on a ranch. When we had lived there for two and one-half years the house where we lived burned down. When we returned in the afternoon there was nothing but ashes and the fire department. Everything disappeared, everything burned. When my husband came home I wasn't there and he was frightened because he thought we were inside the house when it burned, but no... God wanted this day that my father and 
brother come for me, and if they hadn't I would have died. The fire started when three tanks of gas exploded.

Participants viewed these living conditions as undesirable, intolerable and dangers from which to escape. Eventually moving into improved living conditions and acclimating to life in the United States required learning many new things, as the U.S. was perceived as very different but also a land offering them opportunity not available at home.

\section{Learning New Things}

Participants' reports on their learning experiences in the United States reveal the steep learning curve needed to navigate this new terrain in their lives. They needed to learn U.S. currency, how to find their way around, how to register their children in school, new foods, and innumerable aspects of life taken for granted by most people. Their anecdotes are telling, if not humorous reminders, not only of the skills involved in daily living, but of their ambitions, hopes and dreams, and gratitudes for simple but important improvements in their lives. They reveal profound cultural changes encountered by indigenous immigrants who nevertheless eclectically integrate these changes with their own cultural ways of doing and living. Learning occurred as a function of necessity, opportunity, or inquiry.

- Tienen uno que aprender rápido porque usted va a una tienda y no sabe ni como pagar. Uno se sube a un bus y no sabe uno, cuanto va uno a pagar. $O$ por decir a veces, ve que enfrente que vienen los asientos para personas mayores... y uno no sabe y se sentó en un asiento para las personas mayores y la persona que va manejando no sabe hablar español y uno no sabe nada de inglés, y les dice, sabes que, puedes pasarte para atrás porque aquí van las personas mayores, o se va a subir tal persona, y uno no sabe ni que dijo... es muy difícil porque a mi me pasó cuando yo llegue. (Paloma)

- You have to learn fast because when you go to the store you need to know how to pay. Or if you take the bus you have to know how much to pay. Or for example, 
the seats in front are for seniors and you sit there. If the bus driver doesn't speak Spanish and you don't know English, he might tell you to move back and you won't know what he's telling you...this is hard because that's what happened to me.

Some women were able to take advantage of opportunities to learn because they had the time and the means to participate, neighbors and agencies that informed them, or because the opportunity presented itself as a condition for work:

- Aquí nos dan tantas oportunidades que a veces nosotros las desperdiciamos y no debe de ser asi. Hay que agarrarlo, hay que, como se dice, hay que luchar para conseguirlo, porque aquí nos los dan en las manos así... Hay personas que a veces yo les digo, aquí hay clases de están dando y uno aprenda, pero no quiere uno aprender. Me gustaría que hicieran todo lo que ellos puedan, lo más posible... porque uno aprende cada ida algo. Yo no sabia leer o escribir y esto me ha enseñando tanto... (Guillermina)

- We have here many opportunities that we at times don't access and that shouldn't be. We have to grab them, fight for them because here, those things are very accessible. Sometimes I tell people, you can find sewing classes, cooking...we can get together, English classes, citizenship classes. I would like everyone to take advantage of them as much as possible...I didn't know how to read or write and and they taught me all these things.

- Lo que yo ganaba en la semana de cuidar a los niños, en quince días me pagaban lo que yo ganaba en una semana por cuidar a los niños. Porque yo estaba aprendiendo en la factoría, pero yo quería aprender y no me quería quedar cuidando niños... yo quería otra cosa mas... yo lo que quería ganar, porque las necesidades eran muchas. (Alondra)

- What I used to make in a week, taking care of the children, I would make in fifteen days because at the factory I was still learning. But I wanted to learn, I didn't want to continue taking care of children. I wanted something different. I wanted to make more money, because the needs were huge.

- Yo me acuerdo cuando vine que no teníamos dinero. El primer año que vivíamos acá, cuando estaba embarazada de la niña. En el hospital me dijeron que aplique en el WICcomo estaba dando pecho. Te dan leche, jugo o frijoles... lo que sea. Yo no conocía eso y mis amigas me dijeron y me llevaron a la clínica y appliqué. $\mathrm{Y}$ me daban mis quesos, mis frijoles, blanquillos, leche y cereal. (Flor de Noche Buena) 
- I remember that when we first came we didn't have any money. The first year we lived here I was pregnant with my daughter. At the hospital they told me to applyto WIC as I was breast-feeding. They will give you milk, juice, beans, and other things. I didn't know about this but my friends told me and took me to the clinic and I applied. They gave me cheese, beans, eggs, milk and cereal.

Some women learned as a function of their own curiosity and spirit of inquiry, and because it was important to their management of their families:

- Venían de la escuela con hambre y yo les decía, pero porque si hay programas en la escuela que les dan de comer, porque no comieron? Me decía, no me gusta, no se que traen encima... que era la pizza... pero yo no lo conocía y no les gustaba...pero yo no lo conocía y ellos no sabia que era la pizza y ya fue a investigar. Cada jueves le daban pizza y yo iba y le decía a la maestra que no les gusta el pan que le dan aquí... que trae tantas cosas encima y yo vengo para ver que es lo que es, verdad, y ella decía es pizza, señora. (Flor de Nochebuena)

- The children came home from school hungry and I didn't know why because there are lunch programs in school. So I asked why they didn't eat and they told me they didn't like the food, and that they didn't know what it was. I didn't know what they were talking about so I went to investigate. I told the teacher the children didn't like the bread here because it had so many things on top of it... and she told me it was pizza.

As they learned, participants became reflective knowers and began to undergo identity changes with new discoveries about themselves as learners. They also revealed the extent to which they lead "the examined life" (Hall, p. 30, 1994), that they continually weighed and balanced the benefits and liabilities of their lives as immigrant women, and as emigres from their homeland. Often, learning gave them a sense of accomplishment, of advancing toward their goals, especially when it was linked to even the most elemental improvements in material conditions of life for their families. These improvements, such as having enough food to feed their families, were deeply meaningful to the participants and generated hope. Motivated sufficiently to keep struggling in the face of adversity from these small advances they consistently resolved to "salir adelante," to keep going. 


\section{$\underline{\text { Saliendo Adelante }}$}

How is it that the indigenous women participants found meaning in their suffering and struggles, and found the inner strength to persist through trials, challenges and tribulations? The future of their children was their pivotal consideration, their primary investment, the way they framed their willingness to continue struggling. The dailiness of their lives became the purchase of their dreams, the price they were willing to pay for aspiring toward a different vision of life:

- Nada más le pido a Dios que me ayude para que me de fuerza, ánimos para hacer mis cosas, eso es lo que le pido a Dios que me ayude para que yo salga adelante con mis hijos, es lo que quiero. (Clavela)

- I only ask God to give me the strength and desire to do what has to be done. This is all I ask, that God helps me to keep going for the sake of my children.

- Aquí es mucha lucha todos los días trabajando, porque también es muy caro pagar muchos miles de dólares, entonces yo pienso que es mucho esfuerzo... mucho esfuerzo y tener el coraje para salir adelante por los hijos. Si es el motivo principal, los hijos. (Camelia)

- Here, every day working is a struggle because everything is very expensive and costs thousands of dollars. It takes great effort and courage to keep going for the children. But it's the children who are the main reason to make the effort.

- Venimos a trabajar por la necesidad que es muy grande. Ya con hijos, por ejemplo, mi hija que salió de la secundaria y que va a entrar a la preparatoria y mi hijo también, entonces son muchos gastos. El sueldo de México es mucho, mucho muy barato. Pienso que la mejor herencia que les puedo dejar a mis hijos, pues es el estudio para que ellos salgan adelante. (Flor de Nochebuena)

- We came to work because the necessity was so great. With children, for example my daughter who just finished Junior High School and is going into high school, as well as my son, the expenses are very high. The salary in Mexico is very very low. I think the best heritage I can leave my children is their education so they can keep going and making progress. 
- A veces me acuerdo y ahora como sea ahora... yo creo que estoy mejor ahora.... A como estaba antes, estaba mal... así que mientras hay vida hay esperanzas... y hay que seguir adelante. (Violeta)

- Sometimes I remember what it was like, and I think I'm better off now. Before it was very bad. Where there's life there's hope and it's important to keep going.

The theme of "saliendo adelante" emerged repeatedly. It symbolized the harbinger of hope to be able to be positive about the future, to be able to have dreams and goals for which to struggle, no matter how simple or complex. Hope outweigned adversity, and together with family and community, infused the participants with the strength to persist through the difficulties of their lives as immigrants and strangers in an alien place.

\section{$\underline{\text { Summary }}$}

The indigenous Oaxacan women in this study crossed myriad borders: geographical borders, historically and socially constructed political and legal borders, borders of culture and language, and personal borders not explicitly identified in this study. Health transitions became embedded in the risks and difficulties of border crossings. The difficulties they encountered were surmounted by persistence, motivated by hope and the realization that returning home for most of them would be an exercise in futility. Their lives as immigrants have not been easy. Adversity became a familiar companion in the complexities of their lives. Although a few returned to Oaxaca, most remain to "salir adelante", in hopes of leaving a better life and heritage for their children. 


\section{Chapter V}

\section{Health Transitions}

Health transitions are deeply embedded in the complexities of the migration experiences among the indigenous women of this study. New health risks surfaced, some identified and described during the crossing of different borders in the previouis Chapter. New health assets were gained through better nutrition, improved possibilities for prenatal care, and greater opportunity for learning about and taking advantage of fertility control methods.

However, some holistic traditional practices were left behind after arrival in the north where in the formal health delivery system reductionist bio-medical models prevail. Participants on both sides of the border described changes in customary health practices. They abandoned some because of the difference in cultures and influences of Western medicine, preserved other practices, and adopted and adapted new practices into their lives. Similarly, as Bade (1994) observed of Mixtec farmworker women, both Mixtec and Zapotec women in this study took primary responsibility for the health management of their families, sometimes in concert with spouses.

Indigenous women migrants and immigrants appraised health conditions by symptomatology, evaluated preventive and episodic health needs, and matched them with select modalities of health care approaches in a patterned sequence ranging from traditional indigenous home remedies to seeking Western professional care for certain 
prevention and illness conditions. Simultaneously the participants exhibited some variability in their appraisal of their own childhood and current health status, and in their beliefs regarding the etiologies of illness experiences. It appears that some traditional indigenous beliefs have been modified from those identified by anthropologists due to the influence of Western thought. Grieshop (1997) found that migration changed beliefs in omens as illness causation among Mixtec males, so it is likely that changing beliefs among the women of this study is related at least in part to length of duration in northern Mexico and the United States.

Participants were not timid about critiquing experiences with Western health delivery services, comparing and contrasting them, and thus surfacing directions for advocacy, the improvement of culturally competent clinical care, and future research needs. This Chapter presents an overview of these health transitions beginning with their experiences in Oaxaca and northern Mexico to highlight changes and mutations shaped by migration, and the preservation of indigenous practices.

\section{Appraising Childhood Health Status}

With some exceptions, participants rated their childhood health as good. Good health existed simultaneously with episodic illnesses, but compromised health resulted from malnutrition and was characterized by the properties of chronicity, severity of illness, or duration of illness. Common pediatric illnesses such as measles (sarampion), mumps (paparas), pertussis (tos ferina) and varicella were viewed as normal childhood experiences, not as illnesses in spite of their potentially lethal or disabling nature. The transient nature of these infections, when survived, identified them as natural expectations: 
- Si, tuve viruela, como todos los niños pero nunca me enferme...la viruela o el sarampión. Me dio paperas también. Como dos veces me pusieron las vacunas. (Guillermina)

- Yes, I had chicken pox, like all children, but I never was ill... it was the chicken pox or the measles. I also had the mumps. I was vaccinated twice.

- Fue una salud buena... este las enfermedades normales que, el sarampión... la varicela, pero nada más, y por lo demás fue buena siempre mi salud...ni paperas ni nada de esas cosas. Nada más esas dos enfermedades me dieron: sarampión y varicela. Todas las vacunas, y lo único que padecí como a los siete años, fue un poco de las muelas. (Maru)

- I had good health, the normal illnesses, measles, the... what's the name, chicken pox, and that's all. I always had good health. No, I never had the mumps. I only had measles and chickenpox. I was vaccinated, and the only other thing I had when I was seven were some bad teeth.

Participants recalled receiving vaccines as children but were unable to specify them by type or interval. Younger participants sometimes referred to vaccination campaigns in their communities when there were epidemic outbreaks of these infections, especially measles, indicating a probable lack of health infrastructure at that time to deliver these immunizations methodically. Although the almost always lethal nature of these diseases that killed so many indigenous people during the first 300 years of the colonial period has disappeared, that they were and may still be endemic in regions of southern Mexico is feasible.

A non-participant Oaxacan immigrant woman working in the formal health services sector claims that there is no reliable organized health data for the State of Oaxaca (Personal Communication, Alejandra Ricardez, Dec. 29, 2000). In Mexico, vaccines against diptheria, pertussis, polio and measles are now routine but may not be organized and accessible at age appropriate intervals in remote regions of the country, especially in indigenous regions where human rights violations abound and indigenes are 
marginalized because of their cultures. Vaccines against rubella and mumps are not routine (i.e. MMR) and have implications for childbearing aged women immigrants who may not be immune to these potentially teratogenic infections.

\section{Compromised Childhood Health}

Only two participants rated their childhood health as not good (compromised), and associated their status with malnutrition that contributed to chronic or severe illnesses that were not considered normal. They held undernourishment responsible for parasitic infections with neurological complications, being too thin, and frequent stomach problems. Being healthy depended on the ability to access sufficient nutritional intake, itself dependent on economic status:

- Será que no teníamos buena alimentación, no comíamos a tiempo y todo eso... esto consistía mucho en nuestra salud... y yo pienso que esa era la razón que nosotros no teníamos muy buena alimentación, como no teníamos lo suficiente. Cuando levantemos la cosecha teniamos suficiente maíz para la comida, frijoles, calabazas y todo asi para comer. Pero cuando se acaba la cosecha ya no tenemos otra vez, y de todas maneras todo el tiempo nos limitábamos. Había mucha desnutrición. Crecí muy flaquita. Cada rato me enfermaba. Me dolía el estómago, y todo el tiempo sufrí de dolor de estómago (Siempreviva)

- We were malnourished from not eating consistently, and this is important for our health. I think the reason we didn't eat right was because we didn't have enough to eat. When the harvest was in we ate fine-corn, beans and squash is what we ate. But when the harvest was finished here we were without anything to eat again, and we were always limited this way. There was a lot of malnourishment. I grew up very skinny and was always getting sick. My stomach hurt, and I was always suffering from stomach pain.

Although other women identified periodic insufficient intake related to seasons of harvest and fallow, or failed harvests of their family's fields, they did not all identify their health status as poor. However, another who judged her childhood health as poor associated her status with insufficient nutrition due to extreme poverty. Her artisan family 
did not farm so hunger was a constant in their lives. She recounted her severe parasitic infections with their complications of seizures during her adolescence:

- Lógica la alimentación era muy raquítica porque éramos muy pobres. Mi padre era un artesano, se ganaba la vida haciendo huaraches... sandalias... eso era en lo que él trabajaba. Entonces no podía sostenernos a todos... nos daba lo que podía... por lógica teníamos parásitos... yo a la edad de dieciséis años tuve convulsiones debido a tanto parásito que tenía. Y me dieron un tratamiento muy fuerte y muy costoso que mis papás venían de Juntla, Oaxaca a entregarme y lo que me entregaban era el medicamento porque a mí me daban convulsiones de tanto bicho. Así fue como fuimos creciendo, con muchas necesidades y muchas carencias... mucho sufrir. (Alondra)

- Logically our nutrition was very rickety because we were very poor. My father was an artisan who made sandals and he couldn't support us well. Logically, we had parasites. When I was sixteen I had convulsions due to so many parasites. I was on a very strong and expensive treatment that my parents got when we went to Juntla, Oaxaca for help. They gave me very strong medication because I was having convulsions from so many bugs. This is how we grew up, with great needs and worries, a lot of suffering.

It is well known that malnutrition due to overnutrition or undernutrition compromises health status in differing ways. Undernutrition reduces the body's immune defenses and increases vulnerability to infections. A recent report from Oaxaca blames malnutrition and the Mexican Federal Social Security health system (SSA) for the deaths of four young children from bronchorespiratory diseases (Figueroa, 2000). The SSA refused to treat the children, but cause of death was determined ultimately to be the consequence of malnutrition and inability to mount a strong immune response. Acute respiratory infections, exacerbated by malnutrition, are the leading cause of mortality in Oaxaca (Sesia, 1990).

Parasites are also ubiquitous in Oaxaca as they are in the world's Majority Countries. Capital investment into public health sanitation infrastructure has been historically neglected, especially in rural, marginalized and impoverished regions, by 
inherited colonial power relations, and the notorious corruption that siphons off the economic resources needed for development. In Oaxaca, gastrointestinal diseases, including parasites, are recognized as the chief cause of morbidity in children between one and 14 years of age (Ashcroft et al., 1998; Barkin et al., 1997; Kearney, 1998; Sesia, 1990; Valdez, 1998).

It is common for some Oaxacans to de-parasite themselves routinely every six months with 3 Grams of Flagyl, the standard one time dose. For minor parasitic infections people use the herb epazote boiled into a tea.

- Ajá, epazote. Eso es bien bueno para los niños para matar los bichos.

(Flor de Mayo)

- Yes, epazote. This is very good for killing parasites in children.

\section{Health Care in Oaxaca}

Rarely did most participants see a physician as children due to their great distance from a doctor, and the prohibitive cost. Affordability and distance were two interrelated dimensions of inaccessibility to Oaxacan physicians or clinics in rural and remote regions of the country in the Mixteca, but women from the Central Valleys where there are greater population densities in small cities and the city of Oaxaca did not experience the problem of distance. Family members, usually a mother, or a village herbalist treated most women during childhood at home with herbal remedies:

- No había ni doctores, ni como nos vamos a atender o.... si hay pero mucho dinero... así que con puro tesito, con té que nos daban para componernos... (Siempreviva)

- There weren't doctors, or any way for us to afford them...yes there are doctors, but they cost too much money. So we were given pure teas to get better.

Another participant recounted how an herbalist (yerbero) healed her of a very high fever: 
- Creo que tenia como ocho años que me dio una temperatura muy fuerte. Mi mamá decía, creo que se va a morir. Y como ahí no había doctores tan fáciles, o sea. teniamos que caminar como cuatro horas para llegar con el doctor, mi mamá nada mas le dijo a una persona que curaba ahí con hierbas y que fuera a ver... y esa persona me curo. No se que me habrá hecho pero me curo... por eso es que estoy aquí. (Ada)

- I think I was eight years old when I had a very high fever. My mother thought I might die. And because there weren't any doctors easily available, or we had to walk four hours to get to one, my mother asked a person who cured with herbs to come and see me... and she cured me. I don't know what she used to cure me, but this is the reason I am here today.

The availability of indigenous healers is an ancient tradition in Oaxaca, and clearly in this participant's mind is someone who saved her life. Simultaneously her discourse points to the presence and knowledge of professional health providers who are potential health care resources if accessible and affordable. It helps explain the use of both home based indigenous healing modalities and the use of Western medicine simultaneously in the indigenous immigrant population. Much as the syncretic practices that resulted from the importation of European Hippocratic medicine during the colonial period influenced health practices of indigenous Mexicans, indigenous migrants continue to syncretize their health practices both in Oaxaca, and in the United States (Austin, 1988; Bade, 1994; Sesia, 1990; Villarruel, 1992). Yet, migration inevitably ushers in changing practices in new settings with different philosophies.

\section{Changing Health Practices}

Migration is a process of leaving behind and crossing into new territories, but migrants also bring with them their pre-migration lives, experiences and cultural and customary ways of being and doing. The indigenous women in this study described similarities and differences in their health practices, many relying heavily on their near encyclopedic knowledge of herbal remedies plus over the counter preparations (OTCs) 
for self-care (remedios caseros). Some of the OTCs, easily accessible to border populations of immigrants, have a questionable safety profile that will be addressed later. Many women simultaneously adopted new practices, learning how to take advantage of opportunities they perceived to contribute to safer outcomes such as pre-natal care, hospital births, and well child clinical care with scheduled immunizations. A number of women also decided the size of their families, and when, where, and how to incorporate family planning into their self-care practices.

Practices they left behind were adaptations to their lives in the north, often necessitated by more restrictive living conditions, changes in family configurations due to fracturing, or demanding work schedules. These changes reflected new opportunities accessed by the participants, and losses endured. These processes are multiple and complex and point to active learning, the scope of change undertaken, and the sophisticated thinking required for adoptions and adaptations in customs.

\section{Leaving Behind Health Practices}

A practice that has endured since pre-Columbian times in Oaxaca is the Quarentena (Burk, Wieser, \& Keegan, 1995), a post partum period of 40 days of rest, relaxation, and therapeutic steam baths (baños de vapores, baños del torito, or temezcal). In pre-Hispanic times the steam baths were thought to repair damage to the nerves caused by the intrusion of supernatural forces (Villarruel, 1992).

Many participants experienced childbirth in Oaxaca, nearly all at home with the assistance of a village midwife, mother, or mother-in-law (suëgra). A couple participants claimed they were alone and afraid during the birth of their first child. During the quarentena the new mother has a chance to bond with her newborn, and "knit her bones" 
together again in therapeutic herbal steam baths (temezcal). Her "suëgra" takes charge of

the house and does all the cleaning, cooking, and sometimes helps care for the newborn, a role that is powerful, important, and no doubt an important source of her identity. One participant described this experience in eloquent detail:

- Cuando se alivian... hay un baño que le dicen, a las mujeres que se acaban de aliviar... se pone como una casa de campaña un baño y ponen muchas piedras con brasas... del carbón, las brasas del carbón y luego ponen hierba y... a que se queme y luego echan agua y todo ese vapor que sale... es como si todo ese vapor entra en el cuerpo... ese vapor y todas esas hierbas son para, para cerrar los huesos... cuando uno se acaba de aliviar pues queda muy pálido... muy... como mucha pancita... como que se vuelve agarra su elasticidad, no? se vuelven a contraer y... por eso muchas... bueno casi todas las mujeres de Oaxaca... van ahí, es el baño, allá le dicen "el baño del torito" porque todo eso es al vapor, se baña al vapor, $y$ todo ese vapor entra en el cuerpo. El olor de las hierbas... y todas esa hierbas le hace sentir mucho major. También para la leche... muchos atoles... también mucho caldo... mucho líquido para la leche. Decía mi mamá que no podíamos cocer, cocinar porque todo eso nos hacía daño... según decía que si barríamos, nos afectaba a la cintura porque los huesos estan abiertos, segun ella decía que los huesos se abrian. Pues todo eso, es dañino para uno.... Yo creo que era muy efectivo porque casi la mujer de Oaxaca no se enferma seguido... es muy sana, no se si ha observado eso.... O con mujeres que platique con usted, casi la mujer de Oaxaca no es enfermiza... pero es porque todo eso, nos tienen mucho cuidado. (Colibri)

- When a woman gives birth, they prepare a little bathhouse like a tent and put a lot of rocks heated with red-hot coals. They add herbs and when they start to burn they throw water onto the hot rocks to build up hot steam. Since a woman who has given birth is very pale and has a bulging belly the hot steam and herbs penetrate her body to restore it to normal, and to close up the bones. That's why most of the women of Oaxaca are so healthy because they all go into these baths, called "the bath of the little bull". The fragrance of the herbs makes one feel so much better. Also, to help with the milk we take a lot of atole (a drink made from fine ground corn meal), soups and liquids. My mother told me that we couldn't sew, cook, or sweep because these things would be harmful, that they would hurt our back because our bones were open. I think that this treatment is very effective because the women of Oaxaca hardly ever get sick, if you've noticed. That's because we take so much care.

This rich description unfolds complex and holistic health practices within a woman centered and controlled, non-medically managed, non-reductionist milieu 
surrounding pregnancy and childbirth. Healing therapies that relax a woman, give her time, and caring are central to this discourse. Fragrant herbs are indigenous aromatherapy. Colibri's perceptions of Oaxacan women as healthy underscores a type of vigor in this population that appears contingent on the strengths and sense of belonging provided by familial and communal relationships. Alondra believes that women who continue the herbal steam baths are very healthy. Although there are women who are not so fortunate to have this supportive network even in Oaxaca if there are ill feelings between a woman and her suëgra, many participants corroborated this continuing healthy practice, once outlawed by the Spaniards but kept secretly alive.

Although maternal mortality rates in Oaxaca are the second highest in Mexico, next to Chiapas, pregnancy and childbirth are nevertheless considered normal. These rates are determined by the number of registered births, so may be skewed by unregistered births since many births are not registered until an infant is six months old in Oaxaca (Noticias, 2000; Sesia, 1990). Rawlings (1998) contends that some of the more shocking maternal mortality statistics in Majority Countries are due not to traditional practices, but to the changing social circumstances of traditional peoples such as the effects of poverty and malnutrition.

The practice of the quarentena and the temezcal with the supportive female relationships that surround childbearing in a traditional setting provides a glimpse of the social and holistic health losses sustained in migration to a Western Eurocentric medical culture. Family fracturing is one dynamic likely exacerbating the loss of this practice in addition to the medical model, and for many immigrant women the need to work soon after delivery. 
Another health practice left behind by some indigenous women is breastfeeding.

Flor de Mayo mourned the loss of this practice when she observed immigrant woman bottle feeding, but recognized that their work schedules impeded this natural and healthy practice:

- Como nosotras las mujeres que hemos dado luz a los hijos, allá que nosotros somos de Oaxaca. Allá nunca los hijos toman leche...con puro pecho criamos a nuestros hijos. Eso es lo natural que Dios dejó, es como una... como se dice, es como una ley digamos que Dios dijo que las mujeres van a tener hijos pero para eso Dios hizo que nosotros las mujeres tenemos pecho... para criar a los hijos. Y ahora en este tiempo ya no, puro biberón, puro biberón. Ajá, mucho aquí, pues en Estados Unidos...la misma necesidad obliga. Es por ejemplo, si ella le da pecho a su hijo... No voy a poder ir a trabajar.

- We women who have had children in Oaxaca...there we never give bottles to our children. We raise our children with only breastmilk. This is the natural way God has made us. It's like a law that God made that women have the children and that's why God made us with breasts, to nurture our children. But in these times now, no, it's pure bottle-feeding. There's a lot of that here in the United States, and it's made obligatory. For example, if a woman wants to breast-feed she won't be able to go to work.

The profundity of this changing practice and its meaning to this woman is illustrated in her belief that breastmilk is from her essence because it's her very blood transformed that gives life to her children, and that of all mothers to their children. This view emerges from a cosmovision that entwines supernatural and natural powers in relationship, reciprocity and balance:

- Ya sabe como porque la leche de una mujer es la sangre de nosotros... pero Dios lo limpio otra vez, ya no es sangre viva... sino que es leche blanca y pura y dulce... es bien bonito. Ya no necesita echarle azúcar, ya no necesita llevarlo para que se caliente, sino que ya está todo hecho ya con dulce y está calientita la leche... es bonito, verdad?

- You know that woman's milk is our blood, but God cleans it and it's no longer blood, but white milk, pure and sweet, so pretty. You don't have to sweeten it with sugar, and you don't have to heat it up because it's already sweet and warm. That's really neat isn't it? 
Breastfeeding is almost exclusively the norm in Oaxaca. The social context in the U.S., with both its symbolism and its real life demands, is inimical to breastfeeding for some women and represents another way that migration is changing health practices. The other health risk and consequence of bottle-feeding turns children's normal dentition into the ubiquitous and expensive pediatric health problem of caries. Both new health assets and new health risks have supplanted health practices left behind.

\section{New Health Assets}

The most important health asset articulated among participants is better nutrition, but this benefit is on the razor's edge of becoming a two edged sword of liability over time for their children and future descendents as they incorporate over nutrition and under exercise into their lives. Bade's (Personal Communication, August 27, 2000) unpublished survey in California among Mixtec farmworkers found high rates of diabetes and hypertension associated with new problems of obesity. Improved nutrition as perceived in this study was contrasted with the privation of insufficient food in both Oaxaca and northern Mexico:

- Todo fue cambio para mis niños porque en México no teníamos suficiente... pasábamos de arrocito, de frijolito o sopita... no pasábamos de eso o un blanquillo... pero aquí ya fue muy diferente su cambio de comer. Porque aquí mi esposo ya trabajaba, teníamos con que comprar las cosas, ya mandaba a traer unos galoncitos de leche, otras cosas... verduras, ya teníamos un poquito mas para los hijos. Y era mejor y es por eso mismo que estamos aquí aguantando... porque por lo menos aquí si estamos trabajando pero tenemos lo poquito para los hijos también y en México no. Porque en México un día que comió frijoles, que bueno ya los comió, ya para otro día ya no tiene... su tortillita con sal. (Flor de Nochebuena)

- Everything has changed for my children because in Mexico we never had enough to eat. We might have rice, beans and soup, but no eggs, so here the way they (the children) eat is very different. Here my husband has work and we can buy milk and other things like vegetables so we have a little more for the children. It's better here so we are staying and putting up with other hardships. At least we can 
work here and have more for the children, but in Mexico, no. In Mexico one day we would eat beans and that was good, but another day we would have nothing but tortillas and salt.

These comments about the inability to access food in Mexico reflect the severity of the impact of the economic crisis in Mexico on Oaxacan migrants. Greater opportunity to access food in the U.S. by Flor de Nochebuena and other women for their families underscores one of the most powerful positive meanings migration has for these participants, and a motivation to persist through difficulties.

Some women took advantage of opportunies for pre-natal care in the U.S. although one woman was denied Medi-cal during her second trimester even with proof of pregnancy, and therefore received no pre-natal care. This denial was illegal under Federal and California law and was antecedent to California's Proposition 187, which sought to deny these services to undocumented immigrants but was defeated in the courts (Martin, 1995). Another woman waited until her last pregnancy to access pre-natal care because she associated it with the need to sign formal permission for a bilateral tubal ligation. Because she had had three children in Oaxaca without problems she went without prenatal care for the $4^{\text {th }}$ and $5^{\text {th }}$ in the U.S., indicating she mistrusted this service, possibly because she thought she'd be pressured into or subjected to sterilization before she was ready.

Whether or not women received pre-natal care they all went to a hospital to deliver. Women without pre-natal care entered through the emergency room when they were in labor. Whether women chose hospital births to ensure their infants were registered as U.S. citizens, or for other complex reasons, one participant felt more safe and secure in contrast to her experience in Oaxaca at home: 
Aquí usted acude al hospital cuando va a nacer su bebe y en Oaxaca no... a nosotros no nos atendía ningún médico, ni enfermera durante el embarazo, solo nos atendía la partera. La niña cuando ella nació de tanta fuerza, yo me desmaye cuando ella cayó, y yo no me sentí segura en ese momento, porque dije, quien me va atender, no hay ni doctora ni clínicas cerquitas... está la clínica pero lejos... entonces yo sentí que dieron un golpazo en la oreja cerré los ojos y dije, hay Dios mío que estará pasando... y yo me quedé como dormida y cuando me acorde había un trapo mojado con alcohol. Por eso yo no me siento segura de tenerlo en la casa... Ahora no, porque yo... cuando nacieron los otros pequeños, yo me sentí segura porque fue en un hospital y no creo que los doctores me dejen. (Flor de Nochebuena)

Here you go to the hospital when you're going to have your baby and in Oaxaca, you don't. During the pregnancy we were not seen by a doctor or nurses, only the midwife. She gives you the check-ups to monitor that everything is going okay. I like the hospital because I feel safer, for me as well as for the child. With the baby girl, when she was born, for so much pushing, I fainted when she came out. I didn't feel safe at that moment because I said, who is going to take care of me? There are no clinics or doctors nearby. The clinic is far. Then I felt like someone hit me hard on my ear, I closed my eyes and I said, dear God, what's going on... and I fell asleep and when I woke up, I had a wet cloth with alcohol on me. This is why I don't feel safe to have them at home... Not now, because with the younger ones, I felt safe because I went to a hospital and I didn't think that the doctor would leave me.

While the issue of perceived safety in a hopital is raised in this data, it is done in contrast with a first childbirth experience at home in which this participant fainted immediately after delivery, a frightening event for her. She also associates hospital births with the security of having someone present to ensure both her and the infant's safety. Supine and lithotomy positions for labor and delivery, although now changing in newer hospital birthing centers, is a change from the squatting or kneeling position at home in Oaxaca that capitalizes on gravity to assist the birth. Participants have noted this difference while apparently accepting it as part of the migration experience of differences and a requirement for the infant's legal status or citizenship.

Another aspect of changing childbirth practices and experiences is the movement from low tech to high tech environments, sometimes perceived as patriarchal intrusion into a natural process by Western feminists. Indigenous Oaxacan women moving from 
home births to clinic and hospital births in northern Mexico and the U.S. also move into a model that has medicalized childbearing and shifted control from a woman centered process to physicians' control (Hubbard, 1990). Although usually and ostensibly eligible for Medi-Cal for pre-natal care and delivery, the women also move from a low cost event to high cost.

Other health assets include the routine newborn injection of Vitamin $\mathrm{K}$ to prevent hemorrhagic disease of the newborn. The administration of silver nitrate drops into the eyes and erythromycin drops are used to prevent neonatal gonococcal ophthalmia and chlamydial eye disease respectively that might result in long term serious sequelae of panophthalmitis and subsequent blindness. Administration of the first Hepatitis B vaccine has become normative before discharge, to be followed by the other two in the series with the initiation of the immunization schedule in the U. S. A potential liability might be a side effect of chemical conjunctivitis from the instillation of silver nitrate drops (Kliegman, 1998).

Many children born to first generation immigrant women in the U.S. are eligible for Medi-cal/Medicaid or the Children's Health Insurance Program (CHIP) initiated by the Clinton Administration, although parents may perceive using these benefits as barriers to eventual documentation. The availability of a regular pediatric immunization schedule at public health departments is a potential asset if immigrants have the means of transportation. The inclusion of vaccines against rubella and mumps is protective for the future reproductive life of female children in the U.S.

A worrisome trend that might interfere with these assets, however, is the oxymoron of the privatization of public health services, effectively diminishing 
availability and therefore accessibility to basic preventive services for immigrant

children. The case of El Paso, Texas exemplified this trend beginning in the mid 1990s, and rapidly plummeted one of the highest immunization rates in the country among El Paso children to among the lowest in the country as satellite public health clinics closed their doors.

Lastly, most of the immigrant women in this study had learned about and decided to use fertility control methods of their choice. These decisions were often based on their own childhood experiences of the privation of food or further education because of unaffordability, which they attributed to the large number of siblings in their families of origin, in addition to gender and political reasons for poverty:

- Me ligaron, porque yo no quería tener catorce hijos, no, no. Yo quería nada más dos y los quería varones, no quería mujeres. Las mujeres sufrimos mucho y yo quería varones y Dios me concedió varones. (Alondra)

- I have my tubes ligated because I didn't want to have fourteen children, no, no. I only wanted two, and males because we women suffer a lot. So I only wanted sons and God granted that to me.

- Me estoy cuidando desde que nació ella. Para mí estuvo bien tener uno y después el otro. Muy lindo, no sé si se dice así, muy lindo tener dos. Es muy hermoso, yo me siento muy a gusto. (Guillermina)

- I was not dilating, and she was not getting enough oxygen, so they decided to do a C-section. No more pregnancies. No, no more, only these two. I'm taking anticonceptive since she was born. So I have one after another. It was good for me to have the boy and then the girl.

The participants exhibited considerable autonomy in their reproductive decisions, either telling their spouses they wanted no more children, or informing them later of a tubal ligation when the topic of adding another child to the family arose. Siempreviva asserts that Indian women in Oaxaca have also begun to take control of their reproductive 
lives vis a vis contraceptive use because of ideas introduced by returning migrants. In Chiapas Zapatista women declared their right to determine the number of children they will bear in the Revolutionary Law for Women as part of the Declaration of the Lacandon Jungle (Ross, 1995). This declaration flows from a growing movement of indigenous women in Mexico that is part of a broader movement for liberation among indigenous people worldwide as they become cognizant of their rights and inherent dignity (Maiguashca, 1994).

As immigrant women identified some health assets in their new environment, they also began to identify new health risks. Those risks not already surfaced in the previous Chapter on border crossings are discussed here. These new risks relate principally to those associated with their work as domestics, as factory workers, or in the fields of agribusiness in northern Mexico and the U.S. These low paying occupations have been reserved principally for migrant and immigrant workers in the U.S.

\section{New Health Risks}

Immigrant women in the U.S worked mainly in domestic labor or in light assembly plants after having transitioned out of farmwork either in northern Mexico or the U.S. Domestic workers recounted stories of acquired allergic responses to cleaning agents after several years of work, especially chlorox, ammonia and aerosols. These chemicals cause burning eyes, scratchy dry throats, headaches, dermatites and dermatoses that were often endured, or that sometimes led to a health practitioner consult, and sometimes led to a change in cleaning agent or attempt at damage control. Women in domestic work wore gloves whenever possible but revealed that some work demanded bare hands because of the delicate finery in homes where they worked. 
- Los químicos que se usan para limpiar en algunas casa son bastantes molestos, como el cloro. Antes yo el clorax lo soportaba bien. Ahora no lo puedo oler porque me produce resequedad en la garganta y me arden los ojos... entonces no puedo utilizar más el cloro, y antes no me hacia daño...porque yo lo utilizaba muy bien y no pasaba nada y ahora ya tengo como unos ocho años, yo pienso que limpio casa, entonces este... afecta los químicos que uno usa, a veces le duele a uno la cabeza por estar oliendo los esprays que usa uno para limpiar y cuando uno espreya los hornos. Aunque se ponga uno la máscara siempre alcanza oler poquito y los ojos también los tiene uno irritados por lo mismo que los químicos son muy fuertes para limpiar. (Camelia)

- The chemicals that I use to clean in some houses can be very strong, like Clorox. I used to have no problems with Clorox, but now I can't smell it because my throat gets dry and my eyes itch. I can't use Clorox any more. Before I didn't have problems because nothing happened to me but now it's been almost eight years that I'm cleaning houses and the chemicals give me a headache because of the fumes and also the sprays to clean the ovens; even with a mask over my mouth, I can still smell the chemicals and the eyes get irritated because the chemicals are very strong. I can't tolerate the ammonia; I just can't use it becauseit's terrible. With the ammonia I get a burning sensation more than with Clorox. My throat gets very dry and also the eyes.

Musculoskeletal problems and fatigue from bending, lifting, stooping, and repetitive movements in assembly work, farmwork and domestic work are other new health risks related to their working lives as these women attested:

- Dolores en la espalda porque eso de estar agachándose para limpiar abajo, subiéndose en la escalera para limpiar arriba, subiendo y bajando... y ya cuando termina uno, ya está uno muy cansada. (Camelia)

- I get backaches from bending down to clean low places, climbing stairs to clean high places, up and down all day. And at the end of the day I'm very tired. Many times, I have to go up and down almost daily, all day long.

- Todo el día estas limpiando tanto movimiento, yo creo que se me canse el brazo y no me tomo nada. Solo cuando me duelen mucho las piernas que a veces, son seis siete horas con la ropa y eso me siento muy cansada de las piernas. (Flor de Nochebuena)

- I clean all day, all that movement, I think that's why my arms get tired... but I don't take anything, only when my legs hurt, because sometimes I'm on my feet, five, six hours, washing clothes, then they feel tired. 
Chemical and toxic exposures were especially egregious among women of the northern Baja region where they had worked or or continue to engage in seasonal farmwork. They also suffered from heat, from contaminated water, from not being properly informed of fumigations, and from lack of regulations governing pesticide use and waiting periods before field re-entry. One woman recounted a story of her own pesticide poisoning and her trouble getting health care through the Government run Social Security system for this emergency situation. Her story could be repeated many times over and fortunately did not have the same fatal consequences as the experience of Ramon Gonzalez (Wright, 1990).

- Yo en una ocasión estuve a punto de salir muy perjudicada de eso y me acuerdo que eran como a las doce cuando fumigaron, y a nosotros no nos dijeron nada, y cuando regresamos de la comida entramos a trabajar, como a las tres de la tarde ya me empece a sentir mal, me sentí mareada con mucho asco y dolor de cabeza. En ese momento yo quería dejar de trabajar pero cuando llego el dueño no le importo y quería ver el trabajo terminado. Después de que salí de mi trabajo... regrese a mi casa entonces les pedí a mis padres que me llevaran al aseguro y cuando llegue ahí, pues no me podían atender porque no llevaba mi tarjeta, entonces mi papá dijo: "Si no la van a tender aquí la voy a llevar a otra parte" $Y$ me llevo a una clínica particular, ahí el doctor me acuerdo que esa vez el doctor tuvo que atenderme pero no nos cobro, tuvimos que, pues... le pedimos que nos diera una oportunidad para poder pagarle, como en pagos, en abonos. (Amapola)

- On one occasion I remember that they went around 12:00 to fumigate and they never said anything to us and when we came back from lunch we started to resume work. Around 3:00 o'clock in the afternoon, I started to feel ill, I felt dizzy and with nausea and headache. At that moment, I felt like stopping my work but when the owner arrived, he didn't want to hear about that, he only wanted the work to be finished. When I got off work, I came back home and I asked my parents to take me to the Seguro and when I got there, they didn't want to treat me because I didn't have my card. Then my father told me: "If you are not going to treat her here, I'll take her somewhere else." And he took me to a private clinic, there, I remember the doctor didn't charge us, we told him that we could pay him in installments, little by little... every fifteen days certain amount of money, that was a lot for us, but I was poisoned... I stayed all day and all night with IV fluids like for 24 hours. 
Other types of new health risks associated with their working lives included inhaling fibers or particulate matter in the garment industry or factory work, such as painting rocks for the housing sector. Prolonged exposures to the sun, to chemical toxins, and to fibers can potentially lead to long term sequelae such as pulmonary fibrosis, dermatatological reactions including cancers, premature cataract formation and pterygium, teratogenic effects on fetal development, adverse neurological or immunological effects on growing children, and hormone disruptions (Colborn, Dumanoski, \& Myers, 1997; Steingraber, 1997; Wright, 1990).

Although it is beyond the purview of this study to elaborate on work related health risks among these participants, this overview from the participants' perspectives suggests there are many practical implications for nursing practice, praxis, and research. They aiso suggest that immigrant women workers suffer and endure certain health problems as inevitable, but that these are areas of emancipatory potential. That they seek relief in self-care measures and in seeking professional help for various health conditions is revealed in emerging patterns of health care seeking.

\section{Health Seeking Patterns}

Participants engaged in both self-care and in seeking health care from professional health care providers. They engaged in self-care and health care seeking for a variety of conditions that ranged from upper and lower respiratory infections, influenzas, musculoskeletal problems, endocrine disorders, pelvic conditions and reproductive care, and the ubiquitous "nervios" (Doyal, p. 43, 1995) described across many cultures in anthropological literature as the "idiom of distress" (p. 45). Because nervios is so common it merits special examination. 
Suffering from nervios or being "nerviosa" was a common state identified by participants that was associated with family fracturing, especially leaving children behind, with fear of detection by immigration agents, and with fear of pregnancy, the use of oral contraceptives and with the peri-menopause. This wide-ranging use of the descriptor nervios is illustrated in various ways:

- Si veo la migra me pongo toda nerviosa y es un peligro... cuando la veo siento, ay no se como un hormigueo, algo raro, una sensación horrible.

(Violeta)

- When I see immigration it makes me very nervous because of the danger. I feel, I don't exactly know how to say it, but like an ant, something strange, a horrible feeling.

- Pero no pastillas ni nada. Por lo mismo que las pastillas me hace muy nerviosa, un caracter muy malo. (Camelia)

- But I don't use the pill at all. The pills make me very nervous and I get very irritable.

Nervios was described in relation to the problem accompanied by a solution as:

- Los nervios es cuando, por ejemplo, mi hija, que estoy pensando en ella y estoy nerviosa como que estoy desesperada... como que... hay momentos que tengo ganas de correr, de llorar, de brincar... no se si es, como le quisiera explicar, es el estrés... según nosotros esos son los nervios de las... que esta desesperado uno...entonces se toma uno el té, se relaja uno y puede uno dormir. (Colibri)

- Nerves is when, for example, my daughter, when I think about her, I get nervous, like feeling desperate. It's like there are moments that I feel like running, crying, jumping. I don't know what is it, how can I explain it to you? It's stress-for us those are nerves-that you feel desperate. Then you take a tea, you relax and are able to fall asleep.

Doyle (1995) perceives that nervios are associated with the domestic lives of women across many cultures in which specific meanings vary. She observes that the condition is especially prevalent in economically poor communities, and in migrant communities making rapid transitions. It seems linked with difficulty in keeping families 
together economically, emotionally, and socially amidst forces that generate opposing contradictions and pressures. In the context of the lives of the indigenous women participants in this study, nervios is an exquisitely rational state, and one prominent arena for self-care. An overall sequence of health seeking surfaced that ranged from self-care in the home to preventive and episodic care seeking with professionals both in the U.S. and in Tijuana, Mexico. Self-care heavily utilized familiar indigenous remedies learned and experienced in Oaxaca and northern Mexico. Patterns of seeking professional care emerged that were characterized by dimensions of affordability and acceptability. Acceptability was further dimensionalized by perceived qualities of the relationality of the provider and efficacy of treatment.

Because most of the participants live within reasonable proximity of the U.S.- Mexico border accessibility to Tijuana physicians and both botanical and OTC pharmaceuticals were feasible, as were prescriptive medications. Participants selected modalities of health care by appraising and prioritizing health and illness conditions, and comparing, contrasting, evaluating and matching the condition with the modality. Invariably, they tried home remedies before seeking professional care for episodic events.

\section{$\underline{\text { Home Remedies (Remedios Caseros) }}$}

First, preventive measure taken in the home depended on perceived etiologies of common illness conditions such as colds, coughs, sore throats and influenzas. Although the literature discusses a belief in object intrusion such as the entry of a malevolent spiritas cause for disease (Bade, 1994; Villarruel, 1992), the participants revealed belief in a 
range of etiologies in the measures they took to prevent illness in their families. Some etiologies reflect remnants of ancient beliefs, but also contemporary and incisive thought.

Besides the role of malnourishment, indigenous women identified exposure to climate changes such as hot to cold and cold to hot, wind (miasmas), insufficient covering such as socks and shoes after a bath, as contributors to illnesses. Alcoholism as a cause of liver disease, aging and the development of "dirty organs" (los organos...estan sucios), repetitive motions related to work such as ironing, chemical contamination of foods, contagion, and bad experiences were also responsible for illnesses. Their actions were directed as much as possible toward ameliorating or avoiding the suspected causes of illness whenever possible.

For illness conditions, participants appraised common ailments by symptomatology and selected familiar remedies that included a variety of herbal preparations and OTCs ávailable on either side of the border. Some OTCs in Mexico are only available by prescription in the U.S. such as Penicillin (PCN) injectibles. Desenfriol, equivalent to aspirin in the U.S., and Neo-Melubrina used for fever reduction, are OTCs available in Mexico. Neo-Melubrina, however, has led to adverse side effects of aplastic anemia in children (Lily Blatt, Personal Communication, October, 2000). The implications of using these OTCs, because of the risk of Reye's syndrome from aspirin use when a viral infection is present, or aplastic anemia, should lead to the sensitive provision of information with safe substitutes suggested. Table 1 on the following page summarizes the use of ethnobotanical home remedies. 
Table 1

Ethnobotanicals Used by Indigenous Oaxacans

Home Remedies (Remedios Caseros)

\begin{tabular}{|c|c|c|c|c|}
\hline $\begin{array}{l}\text { Plant name } \\
\text { Spanish/English }\end{array}$ & $\begin{array}{l}\text { Conditions/Symp- } \\
\text { toms for Use }\end{array}$ & Preparation \&Method of Use & Toxicity/Precautions/Variations & Latin Botanical Name \\
\hline $\begin{array}{l}\text { Arnica Mexicana/Camphor } \\
\text { Weed/Telegraph Weed }\end{array}$ & Injuries & $\begin{array}{l}\text { Brewed as a tea \& taken } \\
\text { to heal injuries }\end{array}$ & $\begin{array}{l}\text { Not a true Arnica which is for } \\
\text { external use only as a liniment }\end{array}$ & Heterotheca spp. . \\
\hline $\begin{array}{l}\text { Azares/Orange and Lemon } \\
\text { Blossoms }\end{array}$ & $\begin{array}{l}\text { Nervios/Anxiety } \\
\text { Fever reliever }\end{array}$ & Taken internally as a tea & No toxicity & Citrus aurantium \\
\hline Canela/Cinnamon & Cough & $\begin{array}{l}\text { Bark is brewed as a tea \& } \\
\text { taken internally often with lemon \& } \\
\text { honey }\end{array}$ & No toxicity & Cinnamomum sp \\
\hline $\begin{array}{l}\text { Epazote/American } \\
\text { Wormseed/Mexican Tea }\end{array}$ & $\begin{array}{l}\text { Parasites/ } \\
\text { Helminths }\end{array}$ & Brewed as a tea and taken internally & $\begin{array}{l}\text { Contraindicated in pregnancy and } \\
\text { cardiovascular disease }\end{array}$ & Chenopodium ambrosioides \\
\hline Eucalipto/Eucalyptus & Cough & $\begin{array}{l}\text { Leaves brewed as a tea taken } \\
\text { internally and steam inhaled }\end{array}$ & None & Eucalyptus spp. \\
\hline $\begin{array}{l}\text { Hojas de Naranjo/Orange } \\
\text { leaves }\end{array}$ & $\begin{array}{l}\text { Nervios/to calm and } \\
\text { help sleep }\end{array}$ & $\begin{array}{l}\text { Leaves brewed as a tea to take } \\
\text { internally }\end{array}$ & None identified & Citrus Aurantium \\
\hline Hoja de grillo or Plantillo & Fever reduction & $\begin{array}{l}\text { Boiled in water and used saturated in } \\
\text { cloth for topical application }\end{array}$ & Unknown & Not located \\
\hline Manzanilla/Chamomile & $\begin{array}{l}\text { Colds/URI/ } \\
\text { Fever reduction/ }\end{array}$ & $\begin{array}{l}\text { Leaves brewed as a tea for internal } \\
\text { use }\end{array}$ & No toxicity. High usefulness & Matricaria chamomila \\
\hline $\begin{array}{l}\text { Piru leaves/Pepper tree } \\
\text { leaves/Pirul }\end{array}$ & Nervios & $\begin{array}{l}\text { Brewed as a tea and taken internally. } \\
\text { (Some uses as an emollient, } \\
\text { expectorant, diuretic or antiseptic) }\end{array}$ & No toxicity & Schinus molle \\
\hline Limon/Lemon Grass & Fever reduction & Brewed into a tea and taken internally & Little toxicity & Cymbopogon citratus \\
\hline $\begin{array}{l}\text { Ruda de la Sierra/Meadow } \\
\text { Rue }\end{array}$ & Nervios & Brewed as a tea and taken internally & None unless taken in large doses & Thalictrum spp. \\
\hline Sabila/Aloe & Nervios & $\begin{array}{l}\text { Chewed or brewed into a tea for } \\
\text { internal use }\end{array}$ & Also used topically for sunburn & Aloe barbadensis \\
\hline
\end{tabular}




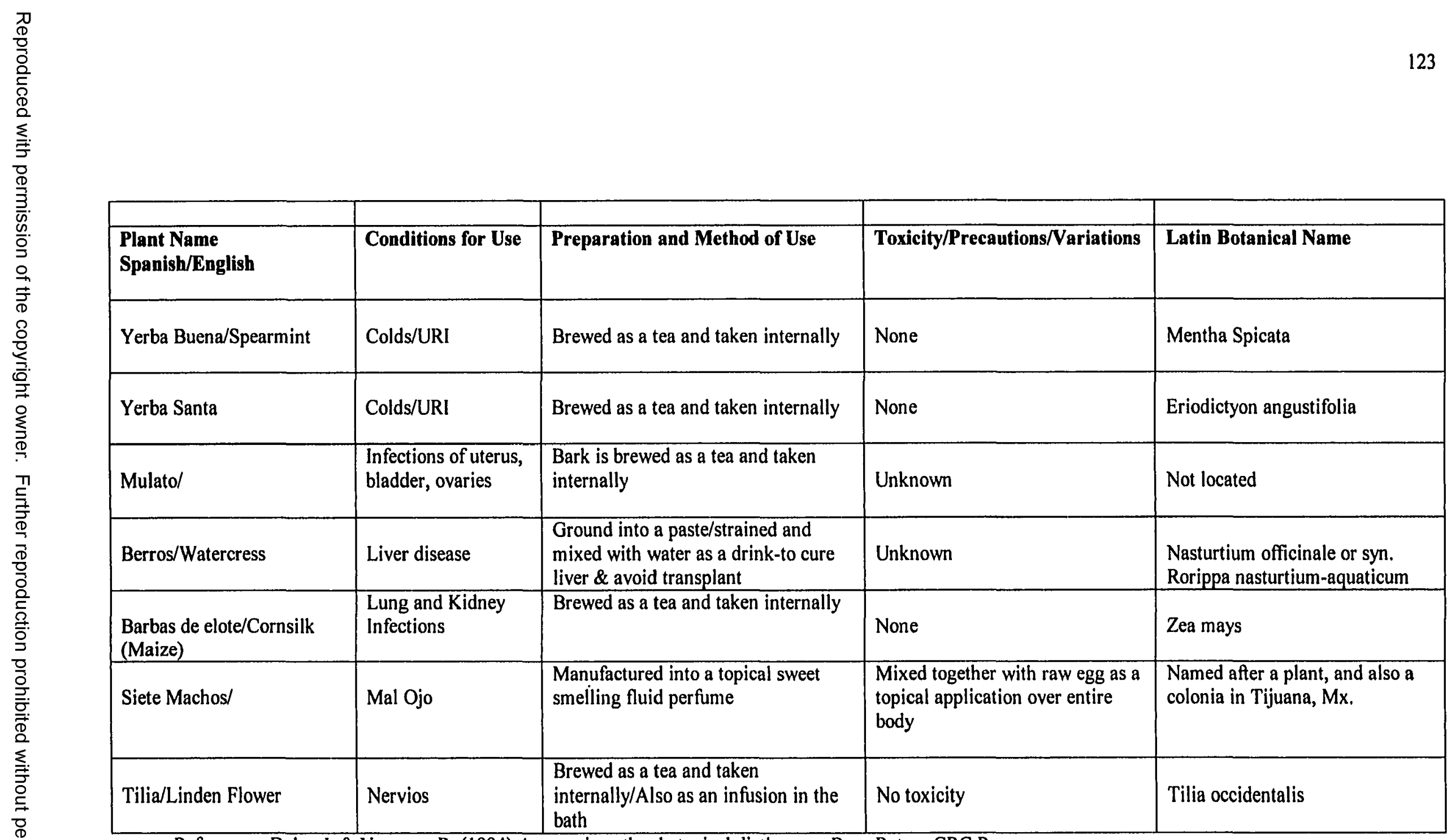

References: Duke, J. \& Vasquez, R. (1994) Amazonian ethnobotanical dictionary. Boca Raton: CRC Press.

Moerman, D. (1998). Native American ethnobotany, Portland, Oregon: Timber Press.

Davidow, J. (1999) Infusions of healing: A treasury of Mexican-American herbal medicine. New York: Fireside.

Moore, M. (1990) Los remedies: Traditional herbal remedies of the Southwest. Santa Fe: Red Crane Books 
Particular health conditions, based both on symptomatology and on traditional indigenous and Hispanic beliefs, were also treated with non-herbal approaches. These conditions and home remedies are elucidated in Table 2.

Table 2

Non-botanical treatments used by Indigenous Oaxacans Home Remedies (Remedios Caseros)

\begin{tabular}{|c|c|}
\hline $\begin{array}{l}\text { Conditions or } \\
\text { Symptomatology }\end{array}$ & Remedies-Preparation \& Use Reported by Study Participants \\
\hline Fevers & $\begin{array}{l}\text { - Thin slices of raw potatoes placed on forehead and soles of feet, } \\
\text { and replaced after } 20-30 \text { minutes or when they tum black. As a cold } \\
\text { remedy for a hot condition they serve to draw out the heat of the } \\
\text { fever. } \\
\text { - Tepid baths followed by towel drying and covering well } \\
\text { - Topical alcohol rubs } \\
\text { - Cold wet cloths applied to forehead and neck } \\
\text { - ASA also given *Risk of Reye's syndrome in children } \\
\text { - OTC Tylenol or Ibuprofen } \\
\text { OTC Neo-Melubrina from Tijuana. *Caution: Red blood cell } \\
\text { suppression }\end{array}$ \\
\hline $\begin{array}{l}\text { Prodromal symptoms of a } \\
\text { cold/URI: Runny nose } \\
\text { and watery eyes }\end{array}$ & $\begin{array}{l}\text { Vaporub liquefied and applied to the chest to help breathing } \\
\text { - Small amount of tequila in which a head of garlic has been crushed } \\
\text { and mixed-given to drink }\end{array}$ \\
\hline $\begin{array}{l}\text { Stomach flu (Resfrio del } \\
\text { estomago) }\end{array}$ & $\begin{array}{l}\text { Scrambled egg with a tea of Yerba Santa, mixture cooled and } \\
\text { applied topically to epigastrium and back to prevent vomiting. Also } \\
\text { to reduce fever... }\end{array}$ \\
\hline *Empacho (Indigestion) & $\begin{array}{l}\text { Soda powder with green tomatoes and lard. Pig fat is washed well } \\
\text { with lime and mixed with the tomatoes. Applied as a paste over the } \\
\text { epigastrium and rub in well before giving something to eat. } \\
\text { If that doesn't work use a little Peppermint and eggs, mixed } \\
\text { together and applied to upper abdomen and back. }\end{array}$ \\
\hline Nosebleeds (Epistaxis) & $\begin{array}{l}\text { Put alcohol on a paper pack and put it in the nose. Put a towel over } \\
\text { it and tie it with a ribbon to create pressure. Keep rubbing up until it } \\
\text { gets better and there's no more bleeding. Do this while applying ice } \\
\text { to forehead. }\end{array}$ \\
\hline $\begin{array}{l}{ }^{*} \text { Mal ojo (Evil } \\
\text { eye)/**Gaze that makes } \\
\text { ill }\end{array}$ & $\begin{array}{l}\text { Pass a raw whole egg entirely over the infant's body to draw out the } \\
\text { evil spirit. Follow this by rubbing down with Siete Machos (bought } \\
\text { in Tijuana) } \\
\text { - Also treated simply with tea of Yerba Buena }\end{array}$ \\
\hline $\begin{array}{l}\text { Cough and chest } \\
\text { congestion }\end{array}$ & $\begin{array}{l}\text { Zorritone: An OTC elixir purchased in Tijuana. Allegedly contains } \\
\text { skunk fat. } \\
\text { - Vics vaporub melted in hot water for inhaling vapors }\end{array}$ \\
\hline Miscellaneous conditions & - PCN injectible (purchased as an OTC from pharmacy in Tijuana) \\
\hline $\begin{array}{l}\text { Reported only: } \\
\text { Lung infections \& Cancer }\end{array}$ & - Rattlesnake meat to be eaten after cooking (Vibora de cascabel) \\
\hline Nervios/Anxiety & $\begin{array}{l}\text { Prayer \& supplication to saints, the Virgin and God were also im- } \\
\text { portant in the personal search for psychological/emotional health }\end{array}$ \\
\hline
\end{tabular}




\section{Seeking Professional Care}

The decision to seek professional care was determined by the outcome of using home remedies for episodic events, or by opportunities for preventive care such as children's physicals and immunizations. The source of professional care was determined by the dimensions of affordability, relationality, and efficacy. Relationality pertains to the perceived relational quality of the provider of care. Efficacy refers to the perception of the practical result of the treatment, rapidity of action, and perceived appropriateness for the condition.

Participants did not distinguish between physicians, nurse practitioners, nurses, medical assistants and receptionists in judging satisfaction or dissatisfaction with health care provision, suggesting how important the ability to relate amicably and forge a personal connection was to them by any involved clinic staff. A receptionist, as an initial contact, could set the overall tone for satisfaction and a sense of being respected in the health setting. A good provider of health services was one who could "atiende bien", that is one who takes good care.

The relationality of the provider was judged by the degree of rapport and friendliness exhibited, the level of interest in the participant as patient/client. Competence was demonstrated through the thoroughness of the health history, the comprehensiveness of the exam appropriate for the health problem or symptoms. A good provider showed respect by listening well and by signaling their recognition that mothers know their children best. As one participant said, "como madre, yo soy la mejor enfermera y doctora porque yo los veo lo que le pasa y lo que les da" (as the mother I am the best nurse and doctor because I'm the one who sees what has happened to them). A good provider also 
approached their children with affection and an understanding of children as evidenced in the way they spoke and physically touched the children.

The use of studies to reach an accurate diagnosis when necessary, and the perceived appropriateness of treatment were also signs of good care that produced satisfaction in an encounter with a professional health care provider. Lastly, participants expressed a strong desire for information sharing as a form of health empowerment.

- Porque uno no sabe y por eso va al médico...porque uno no sabe porque es lo que causa el dolor... o porque le molesta o porque se enfermó uno de eso o que es lo que ocasiona que uno se enferme de eso... así que no le explican a uno y uno se queda con las dudas de porque. Nada mas se queda uno y le dan la receta y ya se puede uno ir. Así que uno nunca sabe. Ponerle mas tiempo al paciente y de escuchar donde le duele y de explicar el porque o como puede prevenir que no le vuelva pasar o como, con el problema del SIDA que le dice a uno, como puede uno prevenir, mas o menos, explicándole a uno como y pues uno ya tiene precaución. (Camelia)

- One doesn't know and that's why one goes to the doctor...to discover the cause of the pain, or why this illness is bothering one. If they don't explain one remains with doubts and wondering. They only give a prescription and then let you go. They need to spend more time with the patient, listening to where it hurts and explaining why, or how to prevent it from happening again. And for example, with the problem of AIDS they should tell you how to prevent it more or less, and explain the precautions needed to prevent it.

Teaching, counseling, and willingness to share information are issues of power relationships between providers and patients/clients, and the provider can be seen as a gatekeeper to information. Withholding information and explanations may be seen as a form of domination over patients. Failure to share information was perceived in a negative light by participants. The dilemma of time allotted to see patients in a managed care environment, a reality even in community based migrant clinics, is a problematic that surfaced, as were the protracted waits that many women endured in community clinics to be seen for their appointments. Poverty, and the need to rely on community- 
based clinics, was no excuse for poor treatment or to be kept waiting for an inordinate amount of time as the women saw it. Both affordability issues and unsatisfactory healthcare experiences in some community clinics pushed the participants who were documented invariably to seek care in Tijuana.

- Muchas personas piensan que los doctores no la atienden bien pero ustedes saben cuando la persona necesita un medicamento entonces, por que no te recetaron algo, y le digo, llévalo mejor a Tijuana. (Flor de Nochebuena)

- This is what happens to the people, that they go and they don't get prescriptions, and so they say "This doctor didn't attend me well. It's better if we go to TJ." And this is the problem we have here. They say, at times, because they don't give us medicines they don't attend us well, so it's better if we go to TJ.

Many participants engaged in professional care for preventive measures such as getting the Papaniculau test or mammogram, and they generally expressed an interest in knowing and learning about these measures. Some were reluctant to access gynecological services because of distaste for the procedures but were aware of the need, which sometimes also conflicted with very busy schedules. A sequence emerged which demonstrated under which conditions specific types of health care were selected according to affordability, relationality and efficacy. This sequence is outlined in Table 3 on the following page. 
Table 3

Sequence of Health Care Seeking

Among Indigneous Women Participants in the U.S.

\begin{tabular}{|c|c|}
\hline Reason for seeking care & Source for finding health care \\
\hline Episodic illness & $\begin{array}{l}\text { 1. Home remedies } \\
\text { 2. Clinics or health centers if undocumented and assured of } \\
\text { safety } \\
\text { 3. ER if undocumented and assured of safety, or uninsured and } \\
\text { very sick } \\
\text { 4. Tijuana if documented (combined with other business to } \\
\text { maximize time spent in travel) and when local treatment } \\
\text { inadequate/not efficacious/complications arose }\end{array}$ \\
\hline $\begin{array}{l}\text { Well child care/routine } \\
\text { immunizations/school physicals }\end{array}$ & $\begin{array}{l}\text { 1. Local public health department } \\
\text { 2. Local community based clinic }\end{array}$ \\
\hline Women's preventive health & $\begin{array}{l}\text { Variable: } \\
\text { 1. Tijuana when affordability was main issue } \\
\text { 2. Local community clinic or private physician }\end{array}$ \\
\hline Pre-natal care & $\begin{array}{l}\text { 1. Local clinic or private physician/private pay or Medical for } \\
\text { vitamins or for signing for BTL (Bilateral tubal ligation) }\end{array}$ \\
\hline Childbirth & $\begin{array}{l}\text { 1. Hospital ER if no prenatal care } \\
\text { 2. Hospital admission per protocol } \\
\text { *All participants wanted children born in the US to ensure } \\
\text { documentation- the ticket to a better future }\end{array}$ \\
\hline Miscellaneous & $\begin{array}{l}\text { 1. Circular/returned migrants waited to get preventive care, } \\
\text { dental care, or other types of care that could wait until they } \\
\text { returned to Mexico because of affordability. } \\
\text { Some chronic conditions, i.e. Type II diabetes, were put on hold until } \\
\text { return to Mexico, and self treated through dietary precautions }\end{array}$ \\
\hline
\end{tabular}

Participants on the Mexican side of the border could not afford private physicians in Tijuana or border communities. Their stories were replete with descriptions of their experiences in the Mexican sponsored social security system of being ignored, mistreated and humiliated. These negative experiences in the Mexican health system reflect a discrimination much written about in other social domains of life among indigenous migrants in the urban shantytowns and northern Baja agricultural region. Simultaneously 
these experiences are helping to shape a strong and inclusive indigenous ethnic identity as a base of strength and struggle (Alfaro, 1991; Kearney, 1998; Nagengast et al., 1990s). This particular community has built its own school and secured a teacher for their children. They are slowly building small and simple brick homes, and collaborating on ways to get electricity and potable water into the community, assets important to health.

\section{$\underline{\text { Summary }}$}

Indigenous migrant and immigrant women undergo health transitions as a consequence of both migration and culture changes. To the extent possible and desirable, they preserve indigenous practices, although there is variability in the degree of reliance on these practices. Similarly, they access Western health care also with varying degrees of reliance, especially when home remedies based principally on herbs do not bring the desired result.

Participants in the border region access Western health care providers in the U.S. for pediatric preventive care such as immunizations, but preferred Mexican physicians on the Mexican side for acute episodic illnesses. Relationality and efficacy were two critical attributes desired in Western providers. The indigenous migrants on the Mexican side struggle with discrimination in health care in the Mexican Social Security system, and rarely can access private physicians because of inaffordability. 


\section{Chapter VI}

\section{Discussion}

In this dimensional analysis of the migration and health experiences of indigenous Oaxacan women, crossing myriad borders emerged as the most comprehensive and intelligible perspective to focus the analysis. Borders are many things. They are boundaries that demarcate, differentiate, and separate while juxtaposing. They can be obstacles, stumbling blocks, enclosures, or frontiers. They can be planiform, linear, circular, imaginary, and metaphoric of social constructions. Borders are also fluid and permeable, able to be changed, reconfigured, or disappeared; to be transgressed and crossed, leaped over or slithered under. They can be regions of negotiated life.

Indigenous Oaxacan women cross myriad borders during their migration and health experiences. Crossing these borders continuously engages their efforts and challenges their resilience and fortitude, raises new health issues and triggers health transitions relative to the vast differences in the worlds of their natal origin and migration destination. Salient sub-dimensions, properties and processes of the border crossings such as undocumentedness, leaving behind, enduring risky living conditions, new health risks and changing health practices have implications for mental, spiritual and physical health. They simultaneously begin to weave together a substantive theoretical understanding of the complexity and multidimensionality of these immigrant women's lives. 
From a postcolonial ecofeminist stance these health issues and transitions have significance for both nursing practice and praxis, and also relevance for other health personnel involved in health care service delivery. Although this study cannot be generalized, the concrete findings and theoretical understandings generated from the data might act as a guide for furthering the work of knowledge development. A feminist emancipatory goal consistent with this type of knowledge development is to improve health care and the quality of life of women, and in this case of indigenous immigrant Oaxacan women. This discussion, then, proceeds from the specific to the general, from concrete to more abstract, from the local to the global, from practice to praxis.

\section{Nursing Practice}

Nursing practice covers the broad areas of clinical practice, research and nursing education at all levels. From this investigation insights emerged that might have applicability without generalizability to these three areas of practice. Clinical practice considerations merit attention especially by school based, community and primary care based, and maternal-child nurses who are most likely to encounter Oaxacan women, children and families along the U.S.-Mexico border for some specific issues, and in the diaspora for others.

\section{Clinical Practice}

Nurses in practice settings conduct health histories and assessments, prescribe therapeutic regimens, teach and counsel, listen, and generate research questions through observations. Building trust is imperative and can start with reaching out, fostering a nonrushed environment, learning the basics of another language (Spanish at minimum), and an attitude of listening and empathy. Great sensitivity to undocumentedness is crucial but 
histories might incorporate into the standard format additional select questions pertaining to:

- Natal origin and childhood health experiences and treatments to understand cultural practices, conditions inducing migration, and changes and losses incurred by migration

- The migration experience and any health related events that might have occurred along the way and crossing the geographical border to be alert to serious health sequelae or mental health issues related to trauma such as anxiety or depression

- Immunization histories especially in adult women of childbearing age

- Work related chemical or toxic exposures, or repetitive motions or bending

- Living environment for safety issues

- Family constitution and dynamics, especially children or family members who might have been left behind

- Nutritional intake patterns

These and other questions incorporated into health histories can help expand noncolonial notions of culture by building an understanding of environment or context for health problems that can later guide research and praxis. Therapeutic regimens that clinic based nurses may need to institute are the full complement of MMR (measles, mumps and rubella) in women of childbearing age with the customary precautions and contraindications, and other immunizations recommended for adults such as tetanus at ten-year intervals. Other therapeutics will depend on the needs identified in the history.

Nurses in border regions should assess for use of Neo-Melubrina as a fever reducer since this OTC from Mexico border towns has been known to suppress red blood 
cell production. Safe alternatives should be identified and encouraged after providing information on the dangers of Neo-Melubrina. Since desenfriol from Mexico is equivalent to aspirin in the U.S. Oaxacan women need to be informed, and also advised about the risk of Reye's syndrome if aspirin is being used for viral infections. Ideas about viruses and syndromes are difficult concepts for pre-and low literate populations whose traditional concepts of disease causation may differ substantially, so visual representations might help.

Indigenous immigrant women need and want information about health conditions and the preventive measures of Western medicine in addition to affirmation for their own non-harmful practices at home. Spending some time offering explanations in simple terminology (in Spanish for those who speak it) regarding diagnoses and medications is a way of empowering and showing respect for the intelligence and desire to learn among these women. Visual aids such as simple anatomic charts and models would be a useful adjunct to verbal information.

Anticipating dietary changes, especially among immigrant children, and the risks for associated chronic conditions like diabetes and heart disease through over nutrition and underexercise, nurses can encourage low fat ethnic foods such as corn, beans and squash prepared with low or no fat. School nurses might be able to influence food choices in school lunch programs, although this task is formidable. School nurses should also be alert to problems of race, culture and language dynamics where indigenous children might be taunted and teased by mestizo chiidren for their short stature and indigenous language. Mestizos have some indigenous heritage and might benefit from realizing the 
cultural achievements of indigenous Meso-America are also a part of their own patrimony.

Nurses should be alert to the mental and emotional health issues among indigenous women who have left family members behind. Leaving children behind creates a deep void, loneliness, and might induce feelings of guilt. Nurses cannot solve the problem of reuniting families directly and immediately but they can offer understanding, support and comfort to help ease the pain in these women. They can refer to culturally appropriate providers for psychosocial support if these services are warranted for any reason, and available in community clinics. Nurses can advocate for the inclusion of these important services where they are missing. Community based nurses usually have a referral network for necessary services and resources, and should make them known. Legal and housing resources may be among the most important.

Nurses working in settings where pre-natal care is provided ideally have an opportunity to assess clients' intentions to breastfeed, to encourage this practice because of the health benefits to both mother and infant, and to help a woman prepare. Studies have found that breastfed infants enjoy bolstered immunity, lower rates of asthma and allergy, and lowered risk for obesity with its risks for heart disease and diabetes Type II (Fooladi, 2001). Given that breastfeeding is the norm in Oaxaca women should be encouraged when possible to continue the practice.

Nurses in maternity units in the U.S. need to be cognizant that the practice of some hospitals to automatically provide formula without inquiring into a woman's desire or her cultural beliefs, norms or logistical ability to breastfeed in a daily life context, better serves the interests of giant formula companies, not necessarily the interests of 
their clients. This is an area where nurses have the power to organize and advocate for policy changes in clinical settings, and to resist being used as free advertising for baby formula companies.

Nurses might search in collaboration with immigrant communities for ways to minimize losses incurred by migration. Leaving behind certain traditional practices might be considered, in terms of healthy, holistic, and therapeutic practices, to be liabilities for indigenous immigrant women and their children. With a better understanding of indigenous perceptions of health, health practices in Oaxaca and continuing practices in the U.S., nurses will be equipped to optimize health care with this population in a way that conserves the benefits of culture complemented with Western approaches to health care. Because the medicinal use of botanicals is a "portable" modality used by Oaxacan women nurses should take advantage of reputable references, ongoing scientific research, and the increasing number of continuing education opportunities to learn about these indigenous resources, and incorporate them appropriately into practice.

\section{Nursing Research}

Research might be guided by bio-medical health and illness phenomena that arise in clinical practice settings, but should also be guided by historical-postcolonial, cultural, social, environmental and feminist (and ecofeminist) paradigms. These latter paradigms establish contexts for health and illness phenomena, fresh perspectives, and potential loci for interventions that are more expansive yet critical because of their influence on health and quality of life. The evolving paradigms likely will continue to generate new research methods consistent with their ontologies and epistemological tenets. 
Many of the health issues raised in this qualitative study are directly connected to the contexts in which immigrant Oaxacan women have found themselves during their life trajectories. Although a focus on outcomes research has been recently popularized, outcomes research will be seriously flawed if it does not include contexts for health at both the individual and population levels. Some general areas for research suggested by the dimensional analysis of this study include but are not limited to:

- The long term mental and emotional health effects of undocumentedness, and of leaving children and other family members behind in Oaxaca

- The relationships between work and health problems for the purpose of developing both individual and social-political interventions

- Intergenerational lifestyle changes among women/parents and children that exert either positive or negative health influences, and the social contexts for these changes

- Preventive care learning processes and decision making processes

- Biophysical and psychological/spiritual life change processes from menarche through the menopause, including risks for heart disease and osteoporosis among indigenous women who have not been included in risk profiles for these conditions. (Participant observation in Oaxaca raised the issue of the existence osteoporosis in Indian women)

- Women's perceptions of health and children's perceptions of health. Another general and critical area for ongoing research should be the effects of economic globalization on health, and exposing these links. This task is especially important as international financial institutions like the IMF and WB require structural 
adjustments and override the sovereignty of nations' abilities to invest in both health care and public health infrastructure.

The Harvard Working Group on New and Resurgent Diseases and other observers are now linking increases in transnational migration with economic globalization and the economic crises wrought by neo-liberal policy changes (Herida \& Purcell, 1996; Mander \& Goldsmith, 1996). Nursing research, especially with immigrant and disenfranchised populations, may be spinning its wheels to its own peril to ignore this contemporary meta-context. Likewise, nursing education needs to continuously introduce global perspectives into curriculum, helping students to expand their horizons. Students need to be challenged to think about global contexts-politics, economics, ecology-for health and culture, and to direct upstream solutions at harmful elements in these contexts in addition to their daily clinical interventions.

\section{Nursing Education}

Postcolonial perspectives dovetail with feminist and ecofeminist perspectives in their epistemes and emancipatory aims. Postcolonial theories should, if they haven't already, be introduced into graduate and doctoral nursing education to nurture greater understanding of the questions of race, class, gender and culture. Although debate about the term "postcolonial" exists, a generally accepted tenet is that political independence of former colonies from European or U.S. imperial control did not necessarily bring economic or cultural independence (Ashcroft et al., 1998; Green \& Troup, 1999).

Inherited colonial and neo-colonial relations of power and their continuing effects on global politics and culture, and therefore health, have lingered with newly emerging elites that transect societies from the local to the global level. Economic globalization has 
become the newest form of colonialism as local and national economies are dismantled in favor of global production and capitalism, creating new migrants and inhibiting endogenous development. Poverty with its pervasive effects is the greatest barrier to health (Hegyvary, 2000; Herida \& Purcell, 1996; Mander \& Goldsmith, 1996). Postcolonial theories can illuminate these contexts. Growing interest in international health and nursing require new understandings that postcolonial, feminist, and ecofeminist perspectives can facilitate.

Lastly, the concept of culture itself is at risk of the limitations of colonial definitions unless it is informed by an understanding of anti-colonial struggles. Mohawk contends that culture cannot develop without an economic base (Golden et al., 1991). If poverty is inimical to health, it is also inimical to cultural development. Nursing's growing emphasis on cultural competence should include an understanding of these power differentials for its emancipatory aims, and guidance in praxis.

\section{Nursing Praxis}

Praxis is a dialectic and dialogic between reflection and action which inform each other as they each evolve. Praxis strives to transform the world in a thoughtful way (Friere, 1968). It can be directed at local, regional, national and global issues and is made efficacious when the engagement is collegial or in solidarity with the efforts of others. In the world of policy and politics nurses can educate legislators and policy makers while advocating for humane immigration laws, socially just health policies, and international fair trade practices that promote authentic development and reduce poverty in Majority Countries. 
An example of international praxis would be acts of international solidarity and advocacy for indigenous economic and cultural rights in Mexico such as emailing, faxing and letter writing to Mexican government officials or U.S. Congresspersons and policy makers. Groups such as the Mexico Solidarity Network or SIPAZ (Servicio Internacional Para La Paz or International Service for Peace) regularly publish online/world wide web updates on indigenous anti-colonial struggles in which many indigenous women play key roles, with suggestions for acts of solidarity.

Praxis to stop human rights violations at the border would be letter writing to overturn (Fix '96) the draconian 1996 immigration law responsible for the militarization of the U.S. Mexico border and the deaths of hundreds of migrants. The American Friends Service Committee (AFSC) and the Interfaith Coalition for Immigrant Rights (ICIR) are backers and promoters of this effort, and of organizing supporters for the necessary momentum to influence Congress. Supporting a general Amnesty bill introduced to Congress for undocumented immigrants to gain legal status is yet another example of praxis that can positively influence the health and quality of life of undocumented immigrant women.

\section{Conclusion}

Indigenous women from the southern Mexican state of Oaxaca predominate in transnational migration to the U.S., crossing myriad borders that redefine their lives and health as they negotiate new terrains, persist through many difficulties, and continue new life trajectories for the sake of the future. To supplement nursing practice at the individual, family and community level, increasing numbers of nurse scholars and activists are urging nurses to engage in praxis. Actions to transform the world require the 
implementation of upstream solutions directed at the context of health phenomena (Butterfield, 1990; Chinn, 1999; Chopoorian, 1986; Drevdahl, 1995; Kleffel, 1991; McGuire, 1998; Stevens, 1989). Praxis that addresses the global environment for health and well-being must also become part of mainstream solutions for nursing in today's world. 


\section{References}

American Academy of Nursing (A. A. N.) (Ed.). (1995). Global migration: The health care implications of immigration and population movements. Washington DC: AAN.

Alfaro, V. (1991). Los Mixtecos en la frontera (Baja California). Mexicali, Mexico: Universidad Autonoma de Baja, California.

Allen, D. (1986). Using philosophical and historical methodologies. In P. Chinn (Ed.), Nursing research methodology. (pp. 157-168) Rockville: Aspen Publishers.

Altink, S. (1995). Stolen lives: Trading women into sex and slavery. New York: Harrington Park Press.

Alvarez R., Butterfield T. (2000). The resurgence of nativism in California? The case of Proposition 187 and illegal immigration. Social Science Quarterly, 81(1), 167179.

Annells, M. (1996). Grounded theory method: Philosophical perspectives, paradigm of inquiry, and postmodernism. Qualitative Health Research, 6(3), 379-393.

Anzaldua, G. (1987). Borderlands/La Frontera. San Francisco: Aunt Lute Books.

Arrazola, V. (2000, 11 de noviembre) Las victimas del Sida fueron recordadas en Oaxaca. El Oaxaqueño, p. 7.

Ashcroft, B., Griffiths, G., \& Tiffin, H. (Eds.). (1998). Key concepts in postcolonial studies. New York: Routledge.

Austin, A. (1988). The human body and ideology: Concepts of the ancient Nahuas (Vol. 1). Salt Lake City: University of Utah Press. 
Aviles, L. (1999). Health and human rights violations at the U.S.-Mexico border. Washington, DC: American Association of Public Health.

Bade, B. (1994). Sweatbaths, sacrifice and surgery: The practice of transmedical health care by Mixtec migrant families in California. Riverside, Ca.: Unpublished doctoral dissertation, University of California, Riverside.

Baker, C., Wuest, J., \& Stern, P. (1992). Method slurring: The grounded theory/phenomenology example. Journal of Advanced Nursing. 17, 1355-1360.

Bancroft, S. (1998, September). Migration: The facts. The New Internationalist. Banks-Wallace, J. (1998). Emancipatory potential of storytelling in a group. Image: Journal of Nursing Scholarship, 30(1), 17-21.

Barkin, D., Ortiz, I., \& Rosen, F. (1997). Globalization and resistance: The remaking of Mexico. NACLA Report on the Americas, 30(4), 14-27.

Barnes, D. (1996). An analysis of the grounded theory method and the concept of culture. Qualitative Health Research, 6(3), 429-441.

Benoliel, J. (1996). Grounded theory and nursing knowledge. Qualitative Health Research, 6(3), 406-428.

Berlinguer, G. (1992). The interchange of disease and health between the Old and New Worlds. American Journal of Public Health, 82(10), 1407-1413.

Berlinguer, G. (1999). Globalization and global health. International Journal of Health Services, 29(3), 579-595.

Blumer, H. (1969). Symbolic interactionism: Perspective and method. Englewood Cliffs: Prentice Hall, New Jersey. 
Boykin, A., \& Schoenhofer, S. (1991). Story as link between nursing practice, ontology, epistemology. Image: Journal of Nursing Scholarship, 23(4), 245248.

Brubaker, R. (1991). International migration: A challenge for humanity. International Migration Review, 25(4), 946-956.

Buijs, G. (Ed.). (1993). Migrant women: Crossing boundaries and changing identities. Providence, RI: Berg Publishers Limited.

Burk, M., Wieser, P., \& Keegan, L. (1995). Cultural beliefs and health behaviors of pregnant Mexican-American women: Implications for primary care. Advances in Nursing Science, 17(4), 37-52.

Butterfield, P. (1990). Thinking upstream: Nurturing a conceptual understanding of the societal context of health behavior. Advances in Nursing Science, 13(3), 1-15.

Calavita, K. (1995). Mexican immigration to the USA: The contradictions of border control. In R. Cohen (Ed.), The Cambridge survey of world migration (pp. 236244). Cambridge: Cambridge University Press.

Carrasco, D. (1990). Religions of Mesoamerica. Prospect Heights, Illinois: Waveland Press.

Castiglia, P. (1994). Health care on the Mexican-American border. In B. Bullough (Ed.), Nursing issues for the Nineties and beyond (pp. 199-211). New York: Springer Publishing.

Castillo B. (1928). A history of the conquest of Mexico. (A. P. Maudsley, Trans.) London: George Routledge \& Sons. (Original from the Chronicles of Bernal Diaz del Castillo) 
Castles, S., \& Miller, M. (1998). The age of migration (2nd ed.). London: Macmillan Press Ltd.

Chenitz, W., \& Swanson, J. (1987). Qualitative research using grounded theory. In W. Chenitz \& J. Swanson (Eds.), From practice to grounded theory (pp. 3-15). Menlo Park, Ca: Addison Wesley.

Chinn, P. (1999). Theory and nursing: Integrated knowledge development. St. Louis: Mosby.

Chomsky, N. (1999). Profit over people: Neoliberalism and global order. New York: Seven Stories Press.

Chopoorian, T. (1986). Reconceptualizing the environment. In P. Moccia (Ed.), New Approaches to Theory Development (pp. 39-54). New York: NLN.

Cockcroft, J. (1998). Mexico's hope: An encounter with politics and history. New York: Monthly Review Press.

Colborn, T., Dumanoski, D., \& Myers, J. (1997). Our stolen future. New York: Penguin Books.

Cook, N. (1998). Born to die. Cambridge: Cambridge University Press.

Cornelius, W. (1982). Interviewing undocumented immigrants: Methodological reflections based on fieldwork in Mexico and the U.S. International Migration Review, 16(2), 378-411.

Crawford, J. (1997). Issue brief: Cycles of nativism in U.S. history. National Immigration Forum. Retrieved November 15, 1998 from the World Wide Web: http://www.immigrationforum.org/cycle.htm 
Crosby, A. (1972). The Columbian exchange: Biological and cultural consequences of 1492. Westport, Ct.: Greenwood Press.

Crosby, A. (1986). Ecological imperialism: The biological expansion of Europe. 900-1900. Cambridge: Cambridge University Press.

Crosby, A. (1994). Germs, seeds \& animals: Studies in ecological history. Armonk, N.Y.: M.E. Sharpe.

Daniels, D. (1989). Always a sister: The feminism of Lillian Wald. New York: The Feminist Press at The City University of New York.

Davis, A. (1984). Spearheads for reform: The social settlement movement and the progressive movement 1890-1914 (2nd ed.). New Brunswick: Rutgers University Press.

Davis, M. \& Haasis, B. (1920). The visiting nurse and the immigrant. The Public Health Nurse, 823-834.

Dobyns, H. (1966). Estimating aboriginal American population. $\underline{\text { Current }}$ Anthropology. 7, 395-449.

Dougherty, M. \& Tripp-Reimer, T. (1985). The interface of nursing and anthropology. Annual Review of Anthropology, 14, 219-241.

Doyal, L. (1995). What makes women sick: Gender and the political economy of health. New Brunswick, New Jersey: Rutgers University Press.

Drevdahl, D. (1995). Coming to voice: The power of emancipatory community interventions. Advances in Nursing Science, 18(2), 13-24.

Dunn, T. (1996). The militarization of the U.S.-Mexico border. Austin: Center for Mexican American Studies University of Texas Press. 
Dwyer, A. (1994). On the line: Life on the U.S.-Mexico border. London: Latin American Bureau.

Editor (1999, 15 de febrero). Mas oaxaqueños vienen a EU. El Oaxaqueño, pp. 1.

Edwards, M. (1997). Central Africa's cycle of violence. National Geographic, 6 (191). 124-133.

Edwards, M. (1997). The sons of Genghis: The great Khans. National Geographic, 2(191), 2-35.

Epstein, P., Cohen, F., \& Larson, E. (Eds.). (1997). Emerging infectious diseases: Symptoms of global change. Washington, D.C.: American Academy of Nursing.

Eschbach, C., Hagan, J., Rodriguez, N., \& Bailey, S. (1999). Death at the border. International Migration Review, 33(2), 430-454.

Ferguson, V. (1997). Response to "Reaffirming the relevance of culture for nursing". Scholarly Inquiry for Nursing Practice, 11. 193-197.

Ferriss, S. (1999, May 30). Harvesting hope. American Statesman International

Field, P., \& Morse, J. (1985). Nursing research: The application of qualitative approaches. Rockville: Aspen Publications.

Figueroa, F. (2000, 28 de Octubre). Por desnutricion mueren 4 niños en San Vicente Coatlan. El Oaxaqueño, pp. 18.

Fooladi, F. (2001). A comparison of perspectives on breastfeeding between two generations of Black American women. Journal of the American Academy of Nurse Practitioners, 13(1), 34-38.

Freedberg, L., \& McLeod, R. (1998, October 13). The other side of the law: Despite all U.S. efforts to curb it, immigration is rising. San Francisco Chronicle, p. A1. 
Friere, P. (1968). Pedagogy of the oppressed. New York: Seabury Press.

Fuentes, A., \& Ehrenreich, B. (1992). Women in the global factory. Boston: South End Press.

Galeano, E. (1997). Open veins of Latin America: Five centuries of the pillage of a continent (2nd ed.). New York: Monthly Review Press.

Garrett, L. (1994). The coming plague. New York: Penguin Books.

Glaser, B. (1992). Basics of grounded theory analysis. Mill Valley: The Sociology Press.

Glaser, B., \& Strauss, A. (1967). The discovery of grounded theory. Chicago: Aldine Publishing Co.

Goffman, E. (1963). Stigma: Notes on the management of spoiled identity. New York: Simon \& Schuster.

Golden, R., McConnell, M., Mueller, P., Poppen, C., \& Turkovich, M. (Eds.). (1991). Dangerous memories: Invasion and resistance since 1492. Chicago: Chicago Religious Task Force on Central America.

Gonzales, P., \& Rodriguez, R. (1999, April 4). Where did Mexicans' ancestors originate? San Diego Union Tribune, pp. G-3.

Gould, W. T. S., \& Findley, A. M. (Eds.). (1994). Population movements from the Third World to the developed world: Recent trends and current issues. New York: John Wiley \& Sons Ltd.

Green, A., \& Troup, K. (1999). The houses of history: A critical reader in twentieth-century history and theory. New York: New York University Press. 
Grieshop, M. (1997). Transnational and transformational: Mixtec immigration and health beliefs. Human Organization. 56(4), 400-407.

Gruzinski, S. (1993). The conquest of Mexico. Cambridge: Polity Press.

Guendelman, S., \& Silberg, M. (1993). The health consequences of maquiladora work: Women on the US-Mexico border. American Journal of Public Health. 83(1), 3744.

Hagedorn, M. (1994). Hermeneutic photography: An innovative esthetic technique for generating data in nursing research. Advances in Nursing Science, 17(1), 44-50.

Hall, J., Stevens, P., \& Meleis, A. (1994). Marginalization: A guiding concept for valuing diversity in nursing knowledge development. Advances in Nursing Science. $\underline{16}(4), 23-41$.

Hattar-Pollara, M., \& Meleis, A. (1995). The stress of immigration and the daily lived experiences of Jordanian immigrant women in the United States. Western Journal of Nursing Research. 17(5), 521-539.

Hatton, D. (1992). Information transmission in bilingual, bicultural contexts. Journal of Community Health Nursing, 9(1), 53-59.

Hatton, D., \& Webb, T. (1993). Information transmission in bilingual, bicultural contexts: A field study of community health nurses and interpreters. Community Health Nursing, 10(3), 137-147.

Hautman, M. A., \& Bomar, P. (1995). Interactional model for recruiting ethnically diverse research participants. The Journal of Multicultural Nursing \& Health, $1(4), 8-15,27$. 
Hegyvary, S. (2000). Editorial: Scholarship for a new era. Journal of Nursing Scholarship. 32(1), 4-5.

Heiney, S. (1995). The healing power of story. Oncology Nursing Forum. 22, 899-904.

Herida, C., \& Purcell, M. (1996). Structural adjustment and the polarization of Mexican society. In J. Mander \& E. Goldsmith (Eds.), The case against the global economy: And for a turn toward the local (pp. 285-293). San Francisco: Sierra Club Books.

Hernandez, J. (1999, January 4). Nuevo fenomeno: Niños indocumentados. El Oaxaqueño. pp. 4.

Heyman, J. (1999). United States surveillance over Mexican lives at the border: Snapshots of an emerging regime. Human Organization, 58(4), 430-438.

Highley, B. (1989). The camera in nursing research and practice, Toward a science of family nursing (pp. xxi-xxvii). Menlo-Park, Ca.: Addison Wesley.

Hinds, S., Chaves, D., \& Cypess, S. (1992). Context as a source of meaning and understanding. Advanced Qualitative Research, 2(1), 61-74.

Hubbard, R. (1990). The politics of women's biology. New Brunswick, New Jersey: Rutgers University Press.

Hune, S. (1991). Migrant women in the context of the international convention on the protection of the rights of all migrant workers and members of their families. International Migration Review. 25, 800-817. 
Huspek, M., Martinez, R., \& Jimenez, L. (1998). Violations of human and civil rights on the U.S.-Mexico border, 1995 to 1997: A report. Social Justice, 25 (2 72), 110130.

Hutchinson, S. (1993). Grounded theory: The method. In P. L. Munhall \& C. J. O. Boyd (Eds.), Nursing research: A qualitative perspective (2nd. ed., pp. 180-212). New York: NLN Press.

Immigration Forum. (1998). Return migration. Who goes, who stays?, Public Policy Institute of California. Retrieved November 15, 1998 from the World Wide Web: http://www.immigrationforum.org/factsonemployment.htm

Kahn, R. (1997, December). Border patrol: Operation Gatekeeper. Z Magazine $12,14-16$.

Kane, H. (1995). The hour of departure: Forces that create refugees and migrants. Washington D.C.: Worldwatch Press.

Kastelein, B. (2000). Letter from Oaxaca. Business Mexico, 10(7), 56-63.

Kearney, M. (1998). Mixtec political consciousness: From passive to active resistance. In D. Nugent (Ed.), Rural revolt in Mexico (2nd ed., pp. 134-146). Durham: Duke University Press.

Kleffel, D. (1991). Rethinking the environment as a domain of nursing knowledge. Advances in Nursing Science, 14(1), 40-51.

Kliegman, R. (1998). Fetal and neonatal medicine. In B. Kliegman (Ed.), Essentials of pediatrics (3rd ed., pp. 167-225). Philadelphia: W.B. Saunders. 
Kools, S., McCarthy, M., Durham, R., \& Robrecht, L. (1996). Dimensional analysis: Broadening the conception of grounded theory. Qualitative Health Research. $\underline{6}(3), 312-330$.

Lange, L. (2000). Burnt offerings to rationality: A feminist reading of the construction of indigenous peoples in Enrique Dussel's Theory of Modernity. In U. Narayan \& S. Harding (Eds.), Decentering the center (pp. 226-239). Bloomington: Indiana University Press.

Leininger, M. (1995). Iranscultural nursing: Concepts, theories, research and practice (2nd ed.). New York: McGraw-Hill.

Leon-Portilla, M. (Ed.). (1990). Broken spears: The Aztec accounts of the conquest of Mexico (2nd ed.). Boston: Beacon Press.

Lewenson, S. (1995). Historical research approach. In H. Streubert \& D. R. Carpenter (Eds.), Qualitative Research in Nursing: Advancing the Humanistic Imperative (pp. 195-212). Philadelphia: Lippincott.

Lipson, J., \& Omidian, P. (1997). Afghan refugee issues in the U.S. social environment. Western Journal of Nursing Research, 19(1), 110-126.

Lowenberg, J. (1993). Interpretive research methodology: Broadening the dialogue. Advances in Nursing Science, 16(2), 57-69.

Lundgren, R., \& Lang, R. (1989). There is no sea, only fish: Effects of United States policy on the health of the displaced in EI Salvador. Social Science and Medicine, $\underline{28}(7), 697706$.

MacEoin, G. (1999, August 13). Ruiz, Marcos changing history in Mexico. National Catholic Reporter, p. 16. 
Maiguashca, B. (1994). The transnational indigenous movement in a changing world order. In Y. Sakamoto (Ed.), Global transformation: Challenges to the state system (pp. 356-382). New York: United Nations University Press.

Mander, J., \& Goldsmith, E. (Eds.). (1996). The case against the global economy: And for a turn toward the local. San Francisco: Sierra Club Books.

Martin, P. (1995). Proposition 187 in California. International Migration Review. $\underline{\operatorname{xxix}}(1), 255-263$.

Martin, P., \& Midgley, E. (1994). Immigration to the United States: Journey to an uncertain destination. Davis, Ca.: Population Reference Bureau.

Martin, P., \& Widgren, J. (1996). International migration: A global challenge.: Population Reference Bureau.

Martinez, R. (1997). Beyond borders: Culture, movement and bedlam on both sides of the Rio Grande. NACLA Report on the Americas, 30(4), 36-39.

Matias, P. (2000, June 24). Elian y Elizama. Processo Sur, 40-41.

Matthei, L. (1999). Gender and international labor migration: A network approach. In S. Jonas \& S. Thomas (Eds.), Immigration: A civil rights issue for the Americas (pp. 69-84). Wilmington, Delaware: Scholarly Resources, Inc.

Mayotte, J. (1995). Protection and health needs of refugee women and girl children. In Global migration: The health care implications of immigration and population movements (pp. 15-22). Washington, D.C.: American Academy of Nursing.

McGuire, S. S. (1998). Global migration and health: Ecofeminist perspectives. Advances in Nursing Science, 21(2), 1-16. 
Meleis, A. (1991). Between two cultures: Identity, roles and health. Health Care for Women International, 12, 365-377.

Meleis, A. (1997). Immigrant transitions and health care: An action plan. Nursing Outlook. 45(1), 42.

Meleis, A., Arruda, E., Lane, S., \& Bernal, P. (1994). Veiled, voluminous, and devalued: Narrative stories about low-income women from Brazil, Egypt, and Colombia. Advances in Nursing Science, 17(2), 1-15.

Melville, E. (1994). A plague of sheep. Cambridge: Cambridge University Press.

Memmi, A. (1965). The colonizer and the colonized (American Edition ed.). Boston: Beacon Press.

Messias, D. (1996). Concept development: Exploring undocumentedness. Scholarly Inquiry for Nursing Practice, 10, 235-251.

Mies, M. \& Shiva, V. (1993). Ecofeminism. New Jersey: Zed Books.

Migrantes. (2000, Verano). Benefician migrantes a millones de familias. Migrantes, 6, 20.

Mittleman, J. (1994). The global restructuring of production and migration. In Y. Sakamoto (Ed.), Global Transformation: Challenges to the State System (pp. 276-297). New York: United Nations University Press.

Molina, T. (2000, 18 de junio). Que las mujeres aprendan a exigir. La Jornada: Masaisare, pp. 6-7.

Monaghan, J. (1995). The covenants with earth and rain: Exchange, sacrifice, and revelation in Mixtec sociality. Norman, Oklahoma: University of Oklahoma Press. 
Monge, R. (1998, August 16). Indigenas en la capital: De la pobreza rural brutal a la pobreza urban violenta e inhumana. Processo, 28-32.

Monsivais, C. (1995). Dreaming of utopia. NACLA Report on the Americas, 29(3), 39-41.

Morse, J. (1992). Editorial. Qualitative Health Research, 2(1), 3-6.

Morse, J. (1994). "Emerging from the data": The cognitive processes of analysis in qualitative inquiry. In J. Morse (Ed.), Critical issues in qualitative research methods. Thousand Oaks, Ca.: Sage.

Muecke, M. (1992). New paradigms for refugee health problems. Social Sciences and Medicine, 35(4), 515-523.

Nagengast, C. (1998). Militarizing the border patrol. NACLA Report on the Americas, 32(3), 37-41.

Nagengast, C., Stavenhagen, R., \& Kearney, M. (1990s). Human rights and indigenous workers: The Mixtecs in Mexico and the United States (Current Issue Brief 4). San Diego: University of California at San Diego Center for U.S.-Mexican Studies. Navarro, V. (1999). Health and equity in the world in an era of "globalization". International Journal of Health Services, 29(2), 215-226.

Noticias. (2000, 2 de junio). 92\% de mujeres fallecidas en parto, no llevaron un control de embarazo, pp. 7A.

Parfit, M. (1998, October). Human migration. National Geographic, 6-35.

Parfit, M. (2000, December). Hunt for the first Americans. National Geographic. 198. 40-67. 
Portes, A., \& Borocz, J. (1989). Contemporary immigrations: Theoretical perspectives on its determinants and modes of incorporation. International Migration Review, 23, 606-629.

Random House Dictionary of the English Language. (1996). Second edition, unabridged. New York: Random House.

Rawlings, L. (1998). Traditional aboriginal birthing issues. Birth Gazette, 14(1), 6-13.

United Nations High Commissioner for Refugees (UNHCR) (1998). Refugees and others of concern to UNHCR - 1998 statistical overview, Retrieved October 19, 1999 from the World Wide Web: http://www.unhcr.ch/statist/98oview/ch1.htm

Reyes, E. (2000, October 14). Casos graves de salud en comunidades, descubre Aseteco. El Oaxaqueño, p. 6.

Richards, L. (1999). Data alive!: The thinking behind NVivo. Qualitative Health Research 9(3), 412-428.

Rivera-Salgado, G. (1998a, February). Naa-shica-dav'i (Los que andan por tierras lejanas). La Jornada, 10. 3-6.

Rivera-Salgado, G. (1998b, August 9). Radiografie de Oaxacalifornia. La Jornada. 2-6.

Rivera-Salgado, G. (1999). Mixtec activism in Oaxacalifornia. American Behavioral Scientist, 42(9), 1439-1456.

Robrecht, L. (1995). Grounded theory: Evolving methods. Qualitative Health Research, 5(2), 169-177. 
Ross, J. (1995). Rebellion from the roots: Indian uprising in Chiapas. Monroe, Maine: Common Courage Press.

Ross, J. (1997, Jan/Feb). Zapata's children: Defending the land and human rights in the countryside. NACLA Report on the Americas, 30, 30-35.

Ross, J. (1998). The annexation of Mexico: From the Aztecs to the IMF. Monroe, Maine: Common Courage Press.

Rothenberg, D. (1998). With these hands: The hidden world of migrant farmworkers today. San Diego: Harcourt Brace \& Company.

Sandelowski, M. (1991). Telling stories: Narrative approaches in qualitative research. Image: Journal of Nursing Scholarship. 23(3), 161-165.

Sassen, S. (1992, July). Why migration? NACLA Report on the Americas, XXVI. 14-19.

Schatzman, L. (1991). Dimensional analysis: Notes on an alternative approach to the grounding of theory in qualitative research. In D. Maines (Ed.), Social organization and social process: Essays in honor of Anselm Strauss. New York: Aldine de Gruyter.

Schwartz-Seller, M. (1994). Immigrant women. Albany: State University of New York Press.

Sesia, P. (1990). Salud y enfermedad en Oaxaca. America Indigena, 50(2), 291308.

Shiva, V. (1997). Biopiracy: The plunder of nature and knowledge. Boston: South End Press.

Shorris, E. (1992). Latinos: A biography of the people. New York: Avon Books. 
Silverstein, N. (1985). Lillian Wald at Henry Street, 1893-1895. Advances in Nursing Science, 7(2), 1-12.

Simon, J. (1997). Endangered Mexico: An environment on the edge. San Francisco: Sierra Club Books.

Simpson, L. B. (1941). Many Mexicos. New York: G. P. Putnam's Sons.

Slemon, S. (1995). The scramble for postcolonialism. In B. Ashcroft, G. Griffiths, \& H. Tiffin (Eds.) The post-colonial studies reader. (pp. 45-52). London: Routledge.

Smith, G., \& Malkin, E. (1997, May 12). The border. Business Week, 64-74.

Smith, R. (1992, July). Mixteca in New York: New York in Mixteca. NACLA Report on the Americas, 25, 39-41.

Spores, R. (1984). The Mixtecs in ancient and colonial times. Norman: University of Oklahoma Press.

Spores, R. (1998). Differential response to colonial control among the Mixtecs and Zapotecs of Oaxaca. In S. Schroeder (Ed.), Native resistance and the pax colonial in New Spain (pp. 30-46). Lincoln: University of Nebraska.

Stannard, D. (1992). American holocaust: The conquest of the new world. New York: Oxford University Press.

Steingraber, S. (1997). Living downstream: An ecologist looks at cancer and the environment. Reading, Massachusetts: Perseus Books.

Stern, P. (1980). Grounded theory methodology: Its uses and processes. Image: Journal of Nursing Scholarship, 12(1), 20-24.

Stevens, P. (1989). A critical social reconceptualization of environment in nursing: Implications for methodology. Advances in Nursing Science, 11(4), 56-68. 
Strauss, A., \& Corbin, J. (1990). Basics of Qualitative Research. Newbury Park: Sage Publications.

Strauss, A., \& Corbin, J. (1994). Grounded theory methodology: An overview. In N. Denzin \& Y. Lincoln (Eds.), Strategies of qualitative inquiry (pp. 158-183). Thousand Oaks: Sage Publications.

Toole, M. (1997). Displaced persons and war. In B. Levy \& V. Sidel (Eds.), War and public health (pp. 197-212). New York: Oxford University Press.

Treviño, C. (2000). Medicina Prehispanica de Mexico. Mexico: Panorama.

Valdez, N. (1998). Ethnicity, class, and the indigenous struggle for land in Guerrero, Mexico. New York: Garland Publishing, Inc.

Varese, S. (1991). Think locally, act globally. NACLA Report on the Americas, $25,12-17$.

Villarruel, A. (1992). Culture and pain: A Mesoamerican perspective. Advances in Nursing Science, 15(1), 21-32.

Wald, L. (1991). The house on Henry Street (2nd ed.). New Brunswick: Transaction Publishers.

Weiss, J. (1992). The U.S./Mexico border. Nursing and Health Care, 13(8), 418424.

Westin, C. (1996). Migration patterns. In M. Haour-Knipe \& R. Rector (Eds.), Crossing borders (pp. 15-30). London: Taylor \& Francis.

Whitmore, T., \& Williams, B. (1998). Famine vulnerability in the contact-era Basin of Mexico. Ancient Mesoamerica, 9, 83-98. 
Winter, M., Morris, E., \& Murphy, A. (1993). The health status of women in Oaxaca: Determinants and consequences. Social Science and Medicine, 37(11), 1351 1358.

Wolf, E. R. (1959). Sons of the shaking earth. Chicago: The University of Chicago Press.

Womack, J. (1999). Rebellion in Chiapas: A historical reader.: The New Press.

Wright, A. (1990). The death of Ramon Gonzalez. Austin: University of Texas Press.

Zabin, C., Kearney, M., Garcia, A., Runstein, D., \& Nagengast, C. (1993). Mixtec migrants in California agriculture. Davis: California Institute for Rural Studies.

Zlotnik, H. (1994). The South-to-North migration of women. International Migration Review, xxix (1), 229-253.

Zolberg, A. (1989). The next waves: Migration theory for a changing world. International Migration Review, 23, 403-430. 


\section{APPENDIX A}

Photo Project

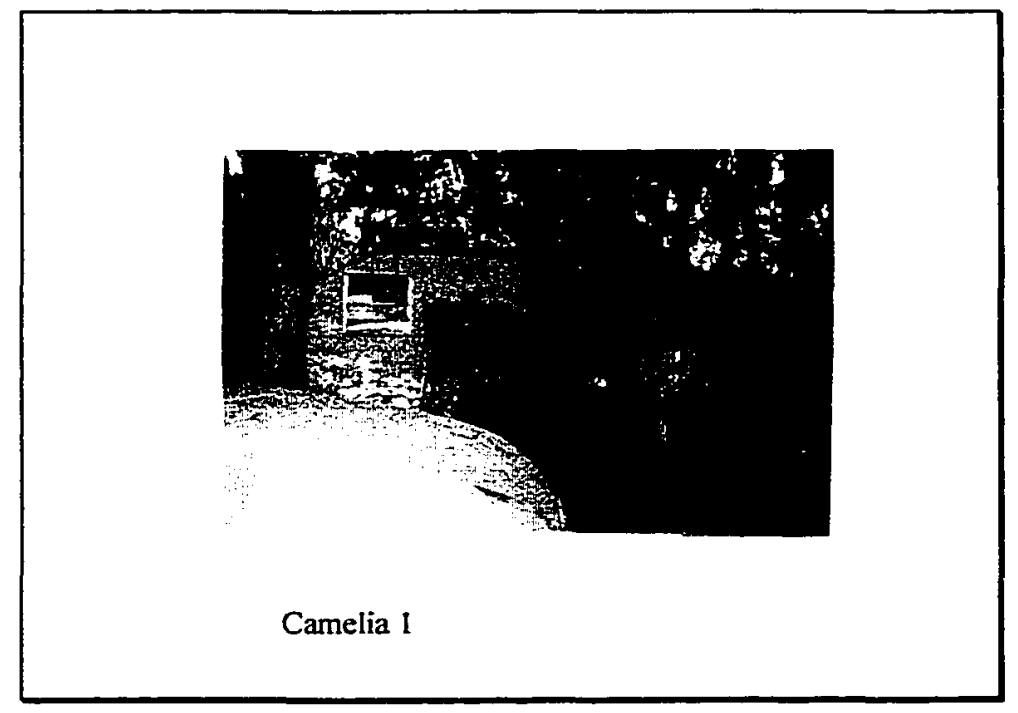

Este es el trailer donde vivía antes, esto es por atrás de la trailer y esto es enfrente como está ahora... pero está muy chiquita por dentro, no tenía un baño ni cocina, solamente para dormir y íbamos a cocinar a otro... en el mismo rancho pero a otro cuarto... ibamos a cocinar porque aquí no se podía, no había baño, no había cocina, no había nada... nada más era para dormir... y cuando hacía frío pues hacía mucho frío [RISAS] sí teníamos muy seguido la gripa y la tos por el cambio de clima, frío... como hay muchos árboles, siempre estaba frío el lugar... y le dábamos de comer a los pájaros y a las gallinas y a todo lo que tenía el señor y eso era donde vivíamos. Era en un rancho donde el señor vendía... criaba pájaros... y entonces este... viviamos, trabajábamos dos horas... trabajábamos por pagar la renta... trabajábamos dos horas dando de comer a los pájaros. Ahí vivimos por cinco años... es mucho tiempo...eso fue todo... 
Slide 2

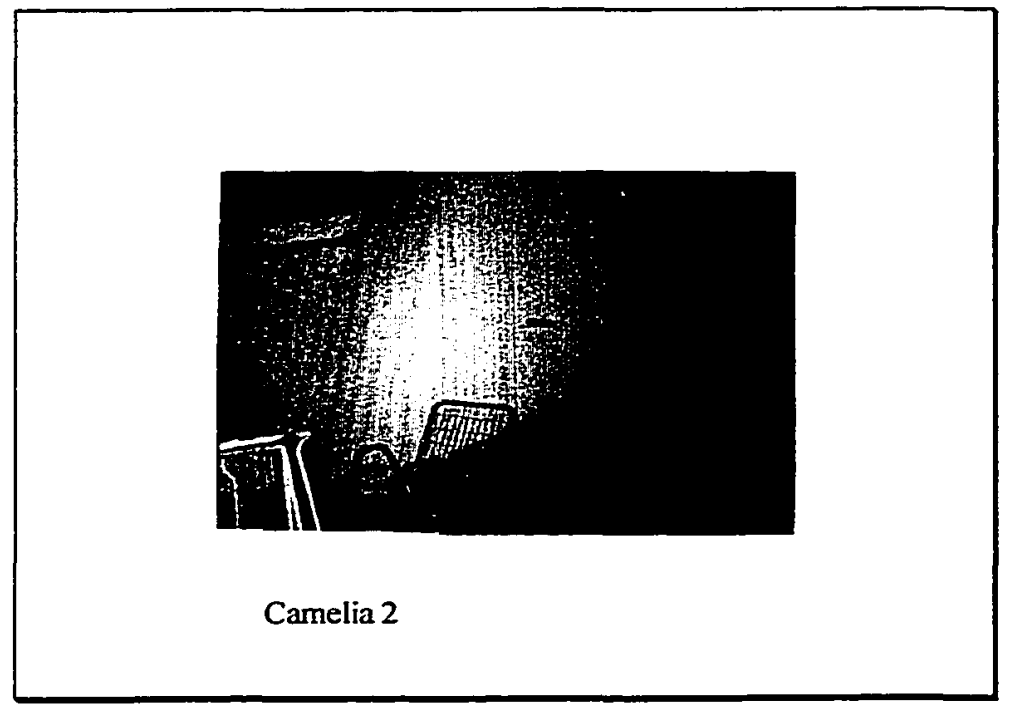

This is the trailer where we used to live, both the back and front of the trailer as it is now. It's very small inside, and it didn't have a bathroom or a kitchen, only a place to sleep.

We had to go to another place on the same ranch to cook because we couldn't do it here. This was only a place to sleep. When it got cold outside we were cold inside and we would always get colds and cough because of the change in the weather. There were a lot of trees around so it was very cold. The ranch owner used to give us birds and chickens to eat, whatever he had because he raised birds. We lived here and paid the rent by working two hours a day feeding the birds. This is where we lived for five years...it was a long time. 
Slide 3

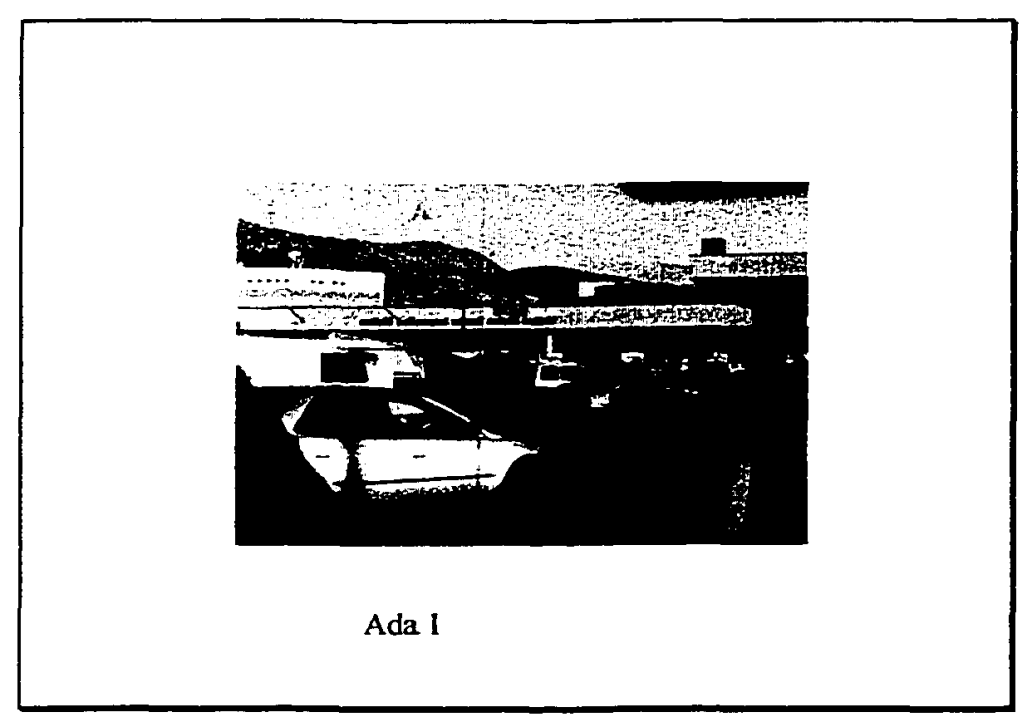

Muy bien empezamos con esta foto... eh, esta cuando uno viene de México para allá... como yo, verdad? que ya tenemos papeles y eso pues cruzamos en la línea, no? Pero en esta... en esta foto se mira el cerro y... y causa... ale... bueno, nosotros estamos bien pero como el cerro como que mirándolo así con, con... que esta muy mal que la gente todavía se cruce así con esta condición... y dice uno, pues, eh... yo en lo personal, yo le doy gracias a Dios que yo fui pasando por la línea, no? pero también pienso en la gente que esta cruzando por el cerro a pesar de las condiciones que ven que ponen las líneas, que son bien duras y pasan niños y mujeres y... es una tristeza muy grande para, pues... para todos los latinos y para los que tenemos papeles pues... dice uno pues que afortunado soy... y entonces en esa condición le pido a Dios... que yo si estoy bien, pero como hariamos para ayudar a las personas que todavía están cruzando... de que manera...entonces uno piensa de toda la comunidad... y luego pues aquí... y luego también aquí... eh, aquí como que dicen the United States Border Inspection a veces no se conforma uno de, de pasar solamente... personas a veces pasan cosas que no deben, que no debemos de pasar y no se que tiempo sea pero [UI]

We are going to start with this photo because this is where people come from Mexico, like me right? We have papers so we can cross the line, but in this picture you can see the hills. We are all right now, but here are the hills where the people still have to cross under these conditions...I personally can give thanks to God for being able to cross the border legally but I think about the women and children crossing through the hills and I am filled with sadness. For all the Latinos and for those who have papers well, one says how fortunate I am... but in this condition I ask God, even though I am fine, how I would be able to help people who are still crossing, in what way? I think about the whole community. Here you see the United States Border Inspection where at times people come across legally but they bring things they aren't supposed to... 
Slide 4

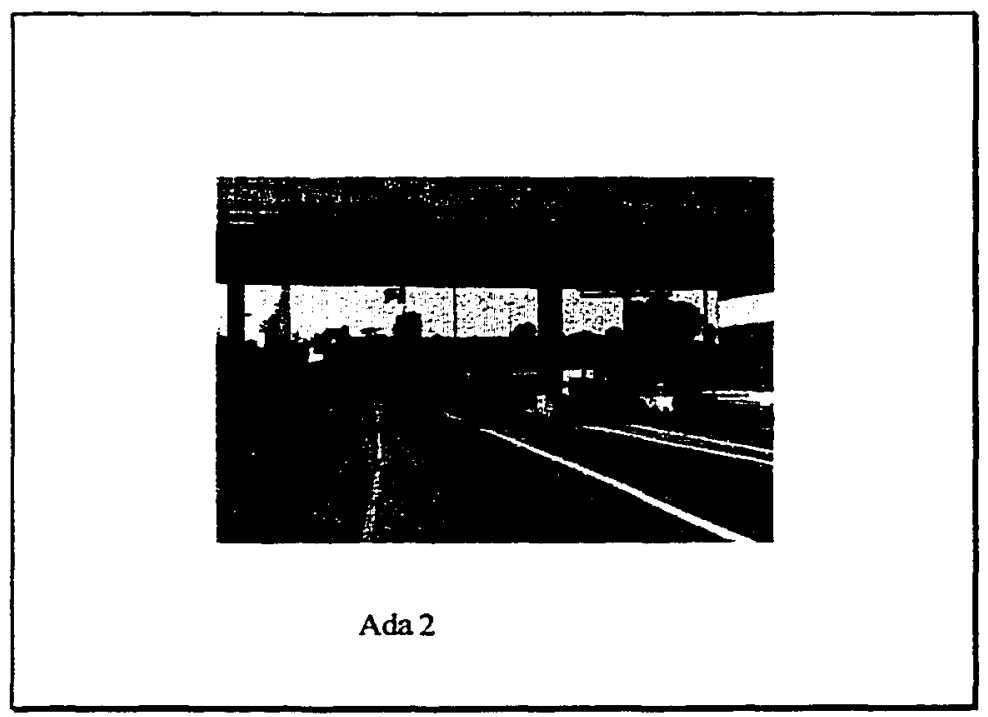

De este lado está California y de este lado está Tijuana, miramos toda la gente todo alrededor de la línea de California esperando... que los carros que cuidan ahí... en la frontera de California, se quiten un rato para ver si pueden pasar, a pesar de que tiene doble cerca. Si sabe eso, verdad? De que tiene doble cerca, la vieja y la nueva que tiene las cámaras y el... las luces que están acá en el field, y la nueva pues esta demasiada alta. La gente ahí esperando que se quiten los carros con la esperanza de poder pasar. Y yo cuando veo, cuando paso por ahí, se me salen las lágrimas porque es una tristeza, no?... de mirar todo eso. Ajá la cerca es esta, la vieja.... es esta y la nueva es esta, pero está muy alta con púas, como con espinas para que la gente no pueda brincarse. Solo hay un camino así para que el carro pueda meterse ahí y este cuidando que la gente no se pase, pero aun así la gente esta esperando ahí, yo no sé, esperando ahí por medio de... así, yo no se si logran pasar o no logran pasar pero están ahí. Están esperando. Pues para mi se me hace injusto... mire como aquí... es la migra... oh entonces ya la encontré... y por acá entra la migra y cuida acá y cuida de este lado también y a veces trae hasta tres, cuatro ahí en la misma parque. Ajá la gente esta esperando de este lado... nada más que nosotros no la podemos tomar tan cerca porque no es bueno verdad? nos paramos ahí y tomar fotos... de ellos porque teníamos miedo de que se enojaran con uno.

On this side is California and the other is Tijuana. We see the people who are lined up waiting to cross into California at the border. They wait to see if they can cross. But look, there's a double fence here, the old one and the new one that has cameras and lights that shine on the field. The new fence is very high. The people wait to see if they can cross sometimes between the cars that are in line. Whenever we pass this spot I start crying for the sadness of seeing all this. This is the old fence, and this is the new one with barbed wire to keep the people from jumping over it. There is a place where they stop the cars to make sure people don't cross. To me this seems unjust. The migra waits here and on this side too, sometimes up to three or four vehicles at the same place. Here's where the people wait on the other side. We couldn't get close to take pictures so we took them from a distance since we didn't want the migra to get angry with us. 
Slide 5

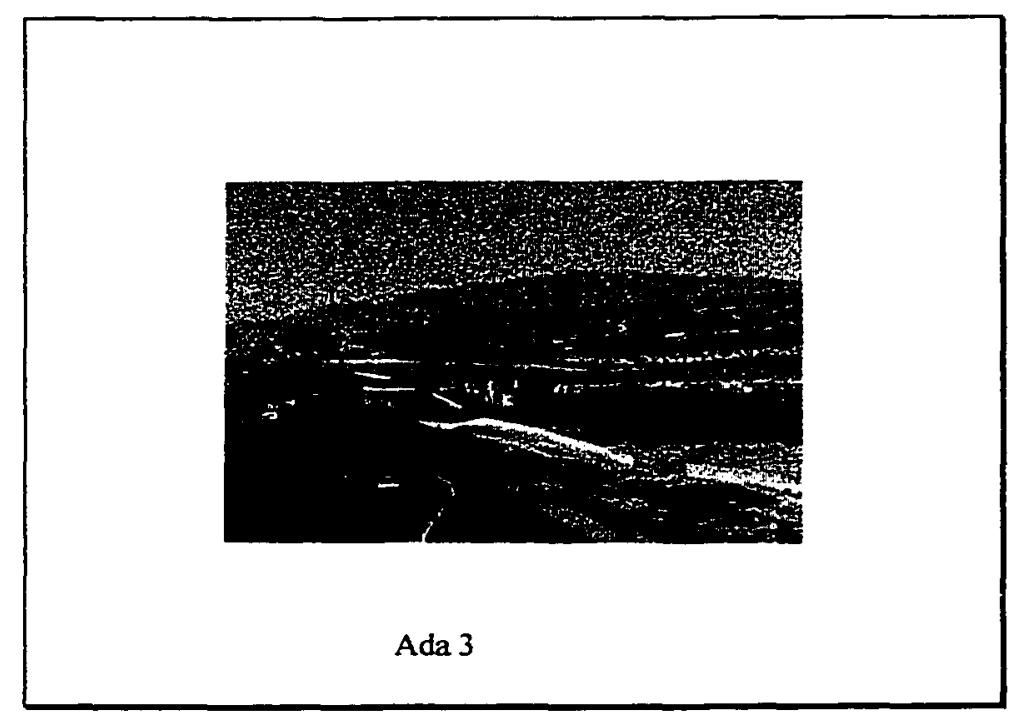

Bueno ya los que estamos aquí. Ya cuando vamos a visitar a nuestra gente de los que se quedaron allá en nuestro país... yo, por ejemplo, aquí miro mi bandera mexicana pues muy grande ahí. Y luego dice México... y bien contentos, no? Hasta los niños andan brincado en el carro que van a ver a los abuelitos y empiezan a hablar de los marranitos y que del perrito y muchas cosas que ellos lo recuerdan y eso... causa como alegría y a la vez como que... no sé, para cuando uno va a ver a la familia... como alegría... y dice, al fin ya me voy. Y eso es lo que es. Les gusta, a mis hijos les gusta al menos a ellos. Si a nosotros nos gusta más... al pais, a la familia... convivir con ellos un rato, porque estar aquí no es tan fácil. Por ejemplo, hubo un caso que pasó este sábado, que mi esposo como toca en la música, como hay otra frontera aquí, que si no tienes papeles no puedes pasar. Una familia esta para allá y otra para acá... y nosotros... no es mi caso, verdad? pero, yo lo veo con otra gente... de que ellos no van a la fiesta porque no pueden pasar y tienen miedo de que los agarren los... y los manden hasta México. Y entonces, o sea, no se puede convivir tan fácil. Y digo, pues es... no, no se vive libremente... y allá pues, donde uno quiera ir o... se convive muy bonito... yo creo que eso es lo que se extraña.

This photo is what we see when we go visit our friends in Mexico. You can see the Mexican flag here, it's really big and it says "Mexico" and we feel really good when we see it. The children are jumping with joy because they are going to see their grandparents, and they start to talk about their friends and such. It gives us great joy to go visit family. My children, even though they like to visit, don't like it as much as we do because it's our country and family and we can live together for a while. It's not easy to be here at all because as my husband plays his music this is another country, another frontier, and if you don't have papers you can't cross. Part of the family is there and part is here as the music goes, although that is not our case. But I see how it is with other people, that they can't go to the festivities because they are afraid they will be captured and sent back to Mexico. We can't spend time together easily the way things are now. We can't live that freely, and in Mexico one can go wherever one wants to, can interact with other people. Those are the things we miss. 
Slide 6

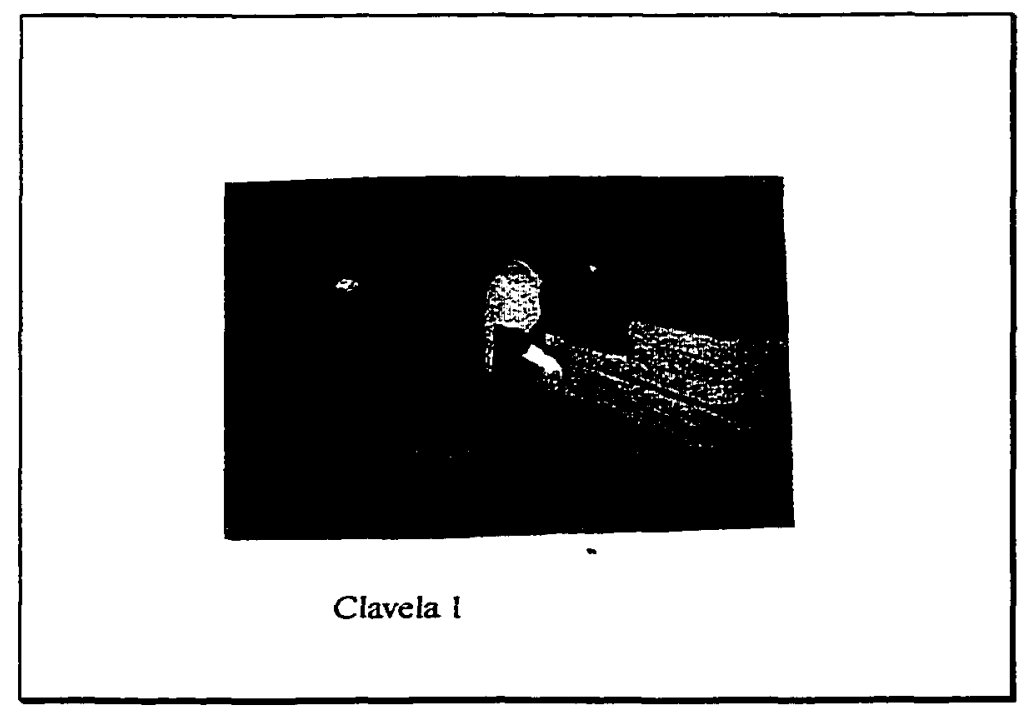

\section{PHOTO 1}

Aquí en esta piedra, nosotros lo estamos pintando... arriba de una banca y aquí tenemos una cubeta de pintura, aquí la vamos pintando... ese es mi trabajo ahorita. . Salió obscuro porque a lo mejor no puse el flash y por eso salieron muy oscuros y así tenemos que tapar la boca todo, y ponernos guantes y todo para mandiles para, este... par que no respiremos el polvo que... hay mucho polvo. Y molesta a los ojos y por eso tengo mala la vista también. Me da como comezón así todo alrededor por lo mismo del polvo hace daño. Si nos dan lentes pero de todas maneras hace daño por eso es que nos tenemos que poner mascarillas... así se llaman estas. Y no se miro bien. Se empieza a las 5:00 de la mañana hasta la 1:30. Ellos entran a la $1: 30$ y salen a las 10:00 de la noche y ya entra otro turno de las 9:00 y ellos sales hasta las 5:00 de la mañana. Son tres turnos. Son para pegar los paredes, por ejemplo, los pilares, si quieren... como quiera el dueño hacer su casa y van pegando ahí las paredes. Para las casa nuevas por eso sacamos diferentes colores... este le decimos, la piedra que estabamos pintado es la "cava"... si tengo que trabajar todo el día parada y con agua, agarramos agua... agua para estar echando ahí. No, no nos dan de comer, cuando salimos a la hora del break de la comida hasta las 9:30. Porque ahí no dan break que por ejemplo... porque por donde quiera tiene que dar unos tres cuatro minutos de break para descansar pero ahí no... ahi vamos trabajando hasta las 9:30, es cuando salimos a comer... para ir a baño no más y ya, a ponerse a trabajar otra vez... aquí pagan un poquito más que el mínimo, este está pagando $\$ 6.75$ y aquí pues $\$ 5$ no más, menos... muy poquito...pues a ver que va hacer el gobierno este ahora... dándonos igual...

Here's the rock that we're painting. It's on top of a bank and there's the container of paint. This is my current work. This turned out dark because the flash wasn't set, but you can see how we have to keep our mouths covered, use gloves and aprons because there's so much dust. It bothers my eyes and that's why I have such bad vision. The dust is irritating and makes my eyes itch and all around them, and I think that's why I can't see 
very well. Yes they give us eye masks but it still hurts our eyes. I start work at 5 in the morning until 1:30 in the afternoon, and then another shift comes in. There are two shifts after mine. They need all these people because the owners of the new houses need their walls and pillars attached together, and they want all different colors of stones. I work all day long on my feet and have to dump water here. They don't give us anything to eat, but we break at 9:30 am to eat. They don't give us a break like in other places where you get three or four minutes to rest... only to go to the bathroom and we're back working again. I make a little more here, $\$ 6.75 \ldots$ better than $\$ 5.00$. We'll just have to see if the Government does anything about low salaries.

Slide 7

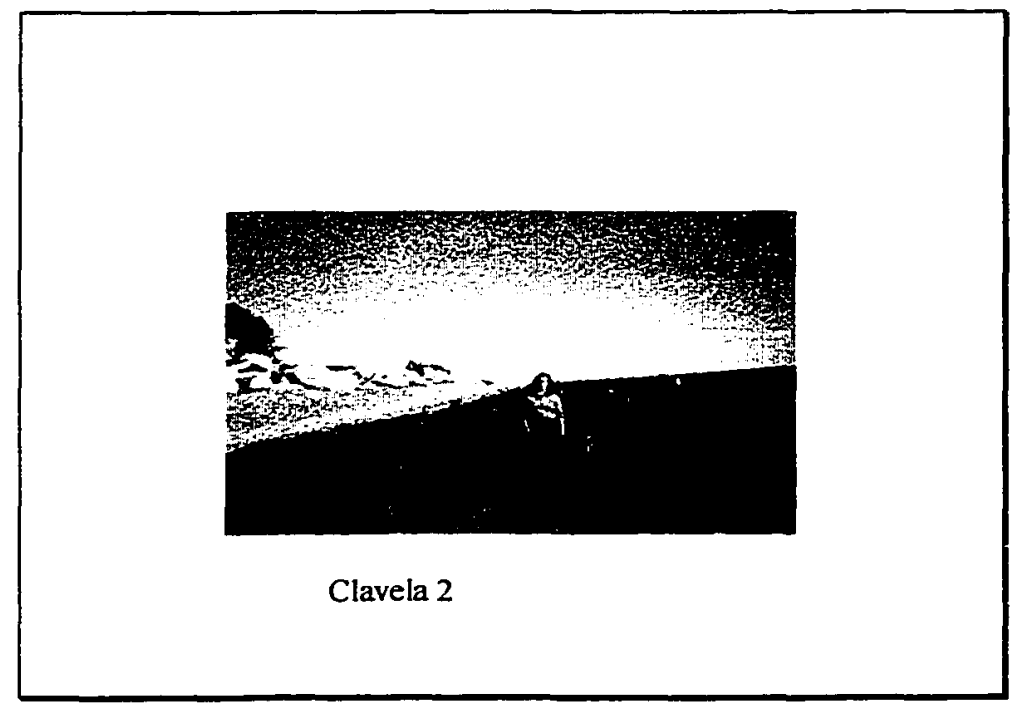

Aquí, y esta, pues este es una hierbita donde trabajaba yo antes. Fui ahí... este es campo... aquí andaba yo trabajando, cortando hierbas. O sea, la hierba de olor para la comida y todo. Me sentía mucho cansada, si porque puro agachada, la cintura... todo el día andamos agachado, cortándolo con un oz así ... lo vamos rasurando para que crezca otra vez. Lo agarramos y lo vamos cortando así. Ahí se ganaba muy poquito... muy poquito pagaban antes. Ellos ponen baños ahí y agua para tomar. Ponen garrafones ahí par tomar agua. Y pues piscando fresas ahí... ahí vamos piscando fresas.

Her is the herb farm where I used to work. This is in the country and is where we cut herbs, the fragrant kind used in cooking and such. I felt very tired because we had to bend over all day, and it bothered my back to be bent over all day trimming the herbs with a special knife so they would re-grow. We'd grab them a certain way and cut like this...I made very little money doing this kind of work. They pay very little but they did supply bathrooms and water to drink. They gave us pitchers of water. I also picked strawberries here. 
Slide 8

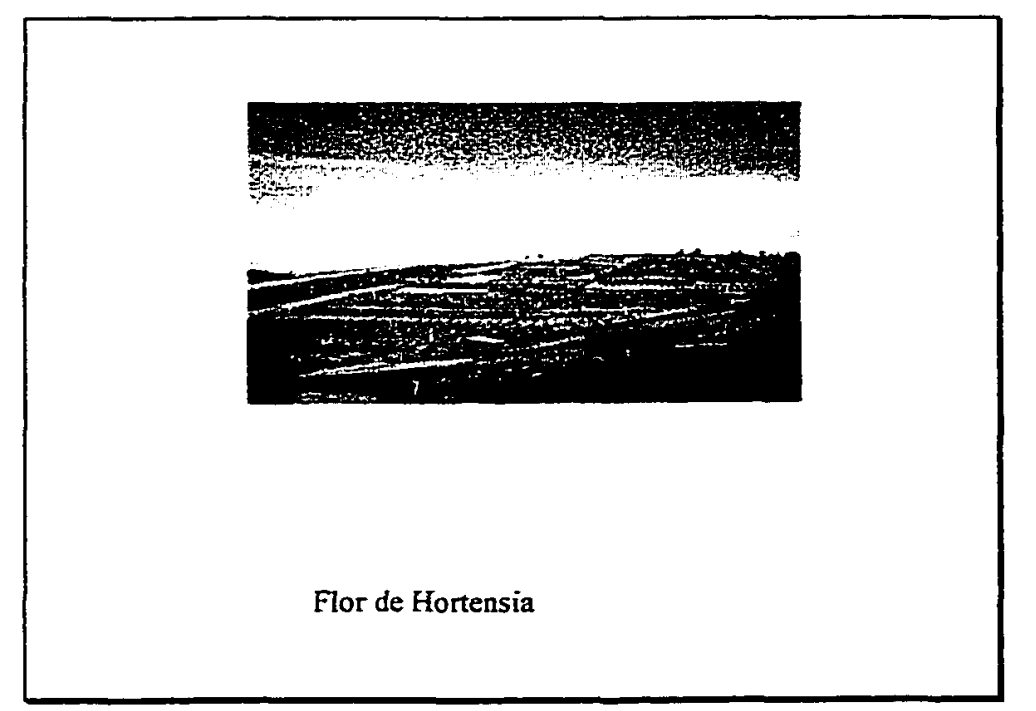

En el $92 \ldots$ estuve trabajando en esta nurseria la primera vez que entré... ya tengo tiempo, nada más que hace poco que entré a trabajar aquí para... una vez que fuimos... fui dificil de plantar pero con el tiempo se aprende porque es mucha... como le diré... quieren que haga las cosa muy rápido... de plantar las plantitas chiquititas... de esa corre en manta y se van plantando seis plantitas pero si está bien difícil para aprender... estuve trabajando como cuatro meses... trabajé en esa un año y al siguiente año otra vez... al siguiente año otra vez también lo mismo me volvieron a llamar para volver a trabajar... si pero pues, es temporal... es temporal de seis meses pero nada más cuatro meses trabajé una temporada y a la otra si cumplí los seis mese... pero es trabajo de campesinos se me hace, todo el tiempo... la gente ya tiene la costumbre de ese trabajo... de la tierra... se nos hace más fácil trabajar en eso que trabajar en otros lugares... me pagaban $\$ 4.25$, el mínimo... me pagaban ahí, ahorita me están pagando lo mínimo también y que es $\$ 6.25 \ldots$ están pagando lo mínimo pero por ahorita ya no estoy trabajando en eso, yo trabajo en una fábrica... ya le dije que trabajo en una fábrica... si es... pues eso nomás puedo decirle de esa nurseria... está en Fallbrook, es la nurseria más grande... no se si la ha escuchado es la "Colorstone"... esta es esa, es una nurseria muy grande, si es la que siempre. Nunca estuve enferma de las plantas, ni de las plantas ni del líquido, solamente del calor para meterlos abajo de las cajas de plástico... ahí sí muy caliente... nada más eso, pero casi no nos afecta nada del líquido o las plantas, ni la tierra... no porque es parado... nada más los dedos movemos, porque como la tierra corre arriba y uno las plantas las tiene enfrente, entonces nada más se plantan abajo. 
Flor de Hortensia continued...

In 1992 when I was first here I worked in this nursery. That was a long time ago, but I was there for a short time. It was difficult to plant the crops but over time I learned a lot. They want you to work very fast to plant the tiny plants. There are six plant in a little flat and it's difficult to learn it properly. I worked here for four months at first, and came back the next year and the next because this is seasonal work for six months at a time. This is the work that farmworkers do because the people are accustomed to this kind of work and usually it's easier than other kinds of work. They paid me the minimum wage of $\$ 4.25$, and where I am working now I am still getting the minimum wage of $\$ 6.25$. But I'm working in a factory now. This photo shows a nursery in Fallbrook. It's the biggest one there and it's called Colorstone. I never got sick from the plants nor from the liquid fertilizer that we put on them, but only from the heat. Going under the plastic was really hot and we were on our feet all day, yet we only moved our fingers to work on the plants in front of us. 
Slides 9 and 10

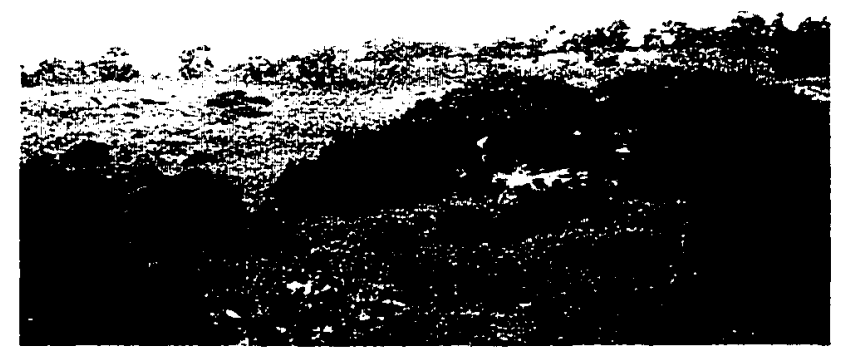

Flor de Nochebuena

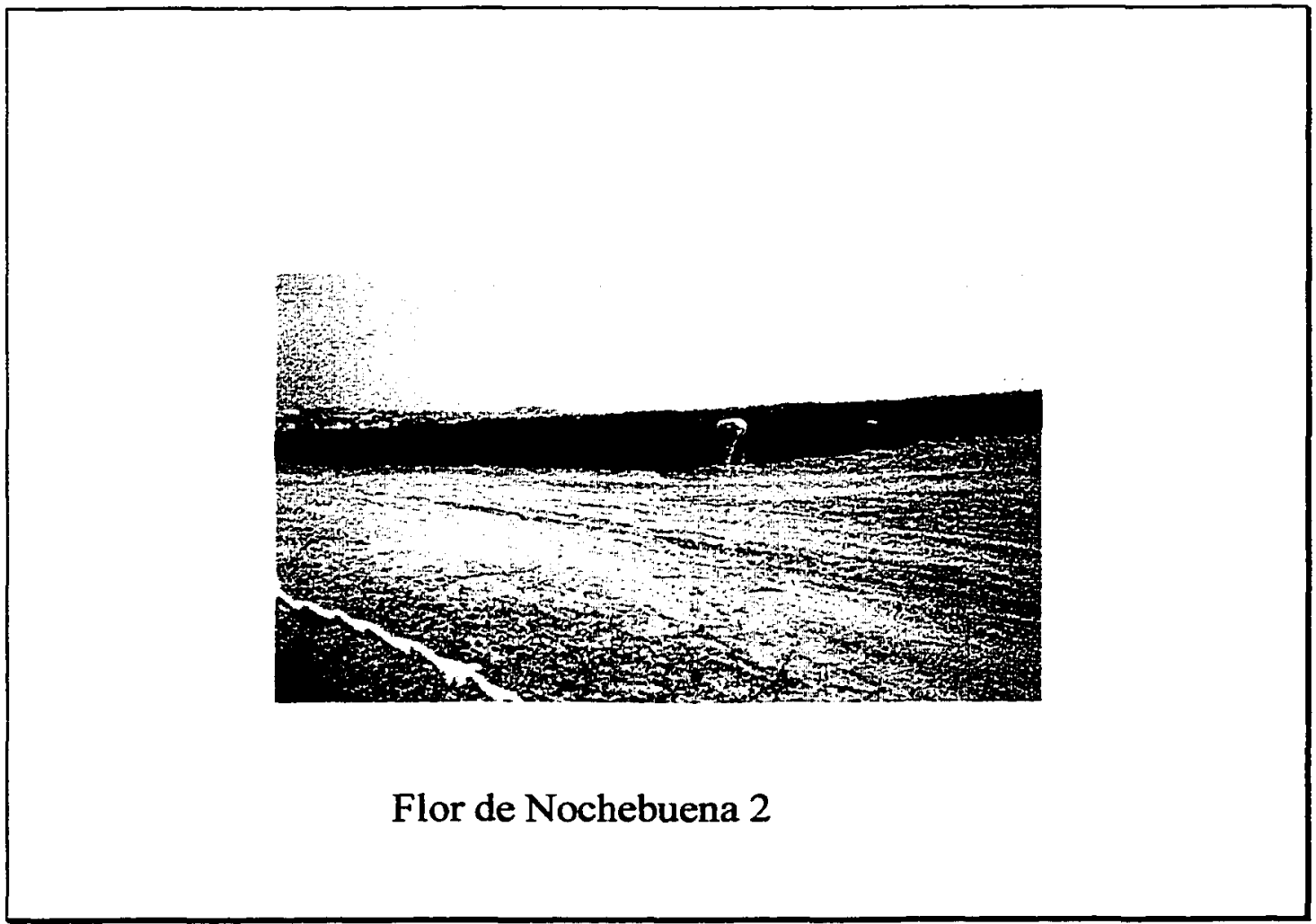




\section{Flor de Nochebuena}

Yo la tomé porque esta persona son las personas latinas que... que hicieron una casitas de, de madera, de cartón para poder trabajar. Porque en una de esas está el tomate donde ellos trabajan aquí... el tomatal donde ellos se van a trabajar, entonces ellos cuando terminan de trabajar las ocho horas que les dan... se vienen a vivir a este monte... Aquí en San Diego, en del Mar... pues esto es algo que veo que me da lástima de la gente de verlos como sufren, que no tienen para... no pueden ellos estar en la ciudad porque como ellos necesitan más dinero, no quieren pagar renta, o tal vez no tengan carro para moverse también... entonces es que esas personas lo que hace es formar su casita en el monte y poder ir a trabajar... un lugar donde les quede más cerca para ir a trabajar... entonces yo veo que es algo duro, dificil para la gente que está viviendo aquí... Pueden enfermarse más pronto por el frío y todo... ahorita por el clima, porque el clima está muy duro por el frío... ellos a veces yo creo que ni cobijas tienen suficiente para cubrirse y se cubren con cualquier sábana o cualquier cartoncito que consiguen ahí aquí es el país más rico en el mundoy mire donde se está quedando la gente... y por que vienen aquí? Porque dicen que el país es muy rico y aquí es donde ellos pueden hacer dinero... pero así se sufre... viviendo en el monte. Son personas que hacen su casita en el monte donde ellos pueden ir a pie a su trabajo. Ellos no pueden rentar en la ciudad, por que? Porque no tienen carro en que moverse a su trabajo. Por eso es que ellos están viviendo en el cerro. A veces dicen que entra la migra y se lleva a varias personas ahí... si eso es lo que nos platican. Y hay que cuidarse mucho, de la migra y de eso ellos nos platican que cuando entra la migra, se echan a correr y si logran agarrar una parte de sus compañeros. Entonces le digo, esto es algo dificil para ellos. Vivir imagínese en un lugar solo... hace tres o cuatro años creo mataron...a murieron dos personas ahí en Del Mar de quemaduras, que se quemaron. Se quemaron, porque su casita se quemó, se encendió, como ellos utilizan velas para que tengan luz a pues se encendió el cartón y que pasó, la persona estaba durmiendo y se quemaron. Dos personas perdieron la vida ahí.... con familias en México... entonces le digo, que esta vida es muy triste para las personas que vienen a luchar y querer ganar dinero a los Estado Unidos. 
Flor de Nochebuena...

I took this picture because these are Latinos here. They made a house of wood and cardboard to be able to stay and work. Near one of those houses there's the tomatoes that they work with...the fields that they work in. When they finish their eight hours of work they come to live in these hills, here in San Diego at Del Mar. This makes me sad because I can see how these people suffer, they have nothing. They cannot be in the city because they need more money, and they don't want to pay rent. Perhaps they don't own a car to get around. So these people build their little houses, shacks, on the hills and to go work... a place that is closer to work. And I can see that this life is hard, difficult for those people who are living here. The can get sick easier because of the cold and everything with the weather. The weather is tough now because it is cold. I think that sometimes they don't ever have enough blankets to cover up with, and they may use a shelter or cardboards that they can get their hands on. Here is the richest country in the world and look where people are staying! And why do they come here? Because this is a wealthy country and they can make money here...but you also suffer living in the hills. There are people who build their little houses on the hills, close to the fields so that they can walk to work. They cannot rent in the city... why? Because they don't have a car to get to work in. That's why they live in the hills. They say sometimes the migra goes in and raids the place, takes people away. That's what they tell us. You have to be careful of the migra. They tell us that when the migra goes in everybody starts running and they take some of the workers. Then, I tell you, this is difficult for them. Imagine living some place alone... Three or four years ago I think two people were killed. Two people died in Del Mar because of burns they got when their little house caught fire. They were using candles for lighting and the cardboard caught on fire. They were asleep and they got burned in their sleep. Two people lost their lives there... with families in Mexico. Then I tell you that this life is a sad life for all the people who come to work, to make money in the U.S. 


\section{Appendix B}

\section{Interview Guide: English version}

1. Tell me a little about where you were born and how your family supported itself.

How was your health as a child?

2. What made you leave Oaxaca?

(If relevant) Describe what it was like to work in the fields in northern Mexico. Did anything make you or your family sick there? How long did you stay and what made you continue your journey north?

3. Did you face any dangers when you tried to cross the border?

What was it like for you? Did you come alone or with someone?

4. Tell me about your work here... what kinds of jobs you've had and what they were like.

Has your work caused you any health problems?

Have you had other kinds of health problems since coming here?

In general how would you evaluate your health?

What about your family's health?

What do you see as the major health risks for you, your family?

5. Do you have a place to get health care?

Tell me about your experiences in looking for HC here in the US?

Have you seen a nurse or doctor in the United States?

Did they explain things to you-like how to use medicines, etc?

Were you satisfied with the health care you received?

6. What have been the most difficult aspects of living in the US?

7. What has been good about living here?

8. What would you want nurses and doctors of the US to understand about immigrant women from Oaxaca?

9. Are you getting preventive HC such as pap smears, flu shots, blood tests for diabetes, dental care...etc.? 


\section{Guia en español:}

1. Platiqueme acerca del lugar donde nacio, donde se crio De que vivia su familia? Como se mantenian?

Como estaba de su salud cuando era niña? (Cuando vivia usted en Oaxaca, como estaba usted de salud?) Tuvo la sarampion o otras enfermidades de niños?

2. Por los cuales razones salio de su pueblo?

Usted o alguien de su familia trabajaron en el norte de Mexico antes de venirse a los Estados Unidos? Por cuanto tiempo? Como les fue por ahi? (Que les parecio ese lugar?) Alguien en su familia o usted se enfermaron o padecieron de algo cuando vivian en ese lugar? Como fue que se decidieron a continuar viajando y a venirse a los Estados Unidos?

3. En su viaje hacia el norte, estuvo su vida en peligro en alguna manera?

(estuvo su seguridad en peligro?)

4. Trabaja usted? En que trabaja?

Platiqueme acerca de su trabajo, que hace

cuando esta trabajando? Su tipo de trabajo afecta su salud en alguna manera?

5. En general, como cree que estos viajes le han affectado su salud?

Como esta la salud de su familia (platiqueme al respecto-de eso). Como estan sus niños de salud? (Estan sus niños sanos/saludables?)

6. Quales son los riesgos mas grandes sobre la salud?

7. A ido usted a alguna clinica o centro de salud aqui en los Estados Unidos?

Como lo trataron los doctores y las enfermeras? Le gustaria decirle algo a las enfermeras y a los doctores? Que tan dificil (facil) es para obtener servicios medicos aqui en los EU? Cuando fue la ultima vez que la miro una enfermera o doctora?

8. Que le gustaria decirle a la gente de los EU acerca de la vida de un inmigrante del estado de Oaxaca?

9. Se previenes con vaccunas, pruebas de cancer (papaniculou), pruebas de sangre, y todo eso? 


\section{Appendix C}

\section{Demographic Data}

Village/town of birth: Region of Oaxaca:

Father's birthplace: Mother's birthplace:

Ethnicity: Age: First language:

Education:

Years living in Oaxaca: *Years living in northern Mexico:

Years living in the US: * * Do you ever make trips back to Oaxaca?

Do you work outside your home?

Type(s) of work: Hours/Wk:

Marital status: Married Single Separated/Divorced

Living with a partner: Number of children:

Sex and ages of children:

Male/Female

1.

2.

3.

4.

5.

*If participant or family engaged in stage migration and worked in Sinaloa or Baja agricultural region.

${ }^{* *}$ Circular migration pattern
Age:
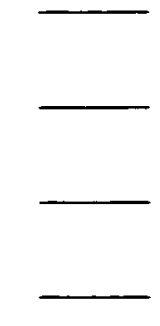


\section{Appendix D}

\section{Translator's Pledge of Confidentiality}

I will be participating in the dissertation research titled:

\section{Migration and Health Experiences of Indigenous Oaxacan \\ Women: A Grounded Theory Study}

I will be present at the interviews to serve as a Spanish language translator as needed. Because I will be privy to the information provided by the participants I pledge to maintain the anonymity and confidentiality of the participants. I will not discuss the information I hear and translate at any time with anyone except the researcher for purposes of clarification when requested. I understand that to violate this agreement would constitute a serious and unethical infringement on the participant's right to privacy.

Signature offftanslator

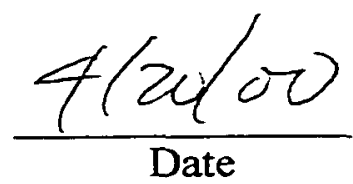

Sharon McGuire

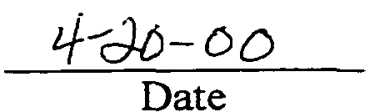

Primary Investigator 


\section{Appendix E}

\section{Transcriber's Pledge of Confidentiality}

I will be participating in the dissertation research titled:

\section{Migration and Health Experiences of Indigenous Oaxacan \\ Women: A Grounded Theory Study}

I will be transcribing audio-taped interviews into text. I will not know the names of the interviewees, but if I recognize information that enables me to identify any of the participants I agree to maintain the anonymity and confidentiality of these people. By signing this agreement I pledge to keep all information strictly confidential. I will not discuss the information I transcribe with anyone for any reason. I understand that to violate this agreement would constitute a serious and unethical infringement on the participant's right to privacy.

Signaflité of Transçiber

Sharon McGuire

Primary Investigator

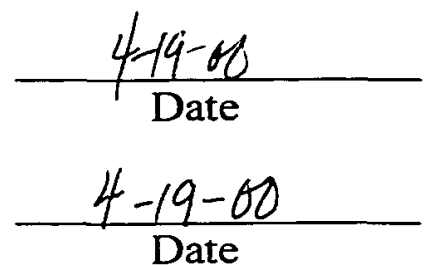

Date 


\section{Appendix F: \\ English Version \\ University of San Diego \\ Research Participant Consent Form}

Sharon McGuire is a doctoral candidate in Nursing at the University of San Diego. She is exploring the experiences and meaning of migration and health among indigenous women from Oaxaca, Mexico. This project will involve one to two interviews. The first interview will last about an hour. The second interview will last about 15 minutes. If I agree to participate I will also have the opportunity to take pictures with a camera that help to tell the story of my experience. The (disposable) camaras will be supplied without cost to me.

This study should not involve any risks to me. I understand the interview will be audiotaped, transcribed and studied in a way that guarantees protection of my identity. My identity will not be disclosed when the findings are reported, and the way they are reported will conceal my identity. I understand that this project will comprise a collective history of migration and health from the points of view of the women who participate. I may choose to use a fictitious name if I wish. When the study is complete the results will be make available to the women who participate.

This consent form contains the only agreements, written or verbal, that will be involved in this study.

Signature of Participant

Date

(Waived per Committee)

Signature of Principle Investigator

Date

*I observed verbal consent obtained from this participant.

Signature of Translator

Date 


\section{Spanish Version \\ University of San Diego \\ Research Participant Consent Form}

Sharon McGuire es un candidato doctoral en la universidad de San Diego. Ella está explorando las experiencias y significar de la migración y de la salud entre las mujeres indígenas de Oaxaca, Méjico. Este proyecto implicará una a dos entrevistas. La primera entrevista durará alrededor de una hora. La segunda entrevista durará aproxidamente 15 minutos. Si usted participa tendré la oportunidad de tomar photos. Eligara lo que me ayudan a contar la historia de mi experiencia. Las camaras serán provistos sin coste yo.

Este estudio no debe implicar ninguna riesgos a mí. Entiendo que la entrevista será grabada en audio, transcrita y estudiada de una manera que garantice la protección de mi identidad. Mi identidad no será divulgada cuando los resultados están señalados, y la manera que están señalados protereje mi identidad. Entiendo que este proyecto abarcará una historia colectiva de la migración y de la salud de las puntas de la opinión las mujeres que participan. Puedo elegir utilizar un nombre ficticio si deseo. Cuando el estudio es completo los resultados serán ponen a disposición las mujeres que participan. Esta forma del consentimiento contiene los únicos acuerdos, escritos o verbales, que estarán implicados en este estudio.

Firma del participante: Fecha (Waived per Committee)

Fecha

Firma del investigador principio

Fecha

* Observé el consentimiento verbal obtenido de este participante. 